Renata Amato Vieira

\title{
Concentrações de mediadores inflamatórios em crianças com idade inferior a três meses e infecção do trato respiratório inferior pelo vírus sincicial respiratório
}

Tese apresentada à Faculdade de Medicina da Universidade de São Paulo para obtenção do título de de Doutor em Ciências

Área de concentração: Pediatria Orientadora: Profa. Dra. Edna Maria de Albuquerque Diniz

São Paulo 2009 
Dados Internacionais de Catalogação na Publicação (CIP)

Preparada pela Biblioteca da

Faculdade de Medicina da Universidade de São Paulo

Creprodução autorizada pelo autor

Vieira, Renata Amato

Concentrações de mediadores inflamatórios em crianças com idade inferior a três meses e infecção do trato respiratório inferior pelo vírus sincicial respiratório / Renata Amato Vieira. -- São Paulo, 2009.

Tese(doutorado)--Faculdade de Medicina da Universidade de São Paulo.

Departamento de Pediatria.

Área de concentração: Pediatria.

Orientadora: Edna Maria de Albuquerque Diniz.

Descritores: 1.Vírus sincicial respiratório 2.Bronquiolite 3.Pneumonia 4.Crianças 5.Mediadores da inflamação 6.Quimiocina CCL5 7.Molécula 1 de adesão intercelular 8.Interleucina-6 9.Interleucina-10 10 .Fator de necrose tumoral alfa 11.Pulmão/secreção 12.Soro 
Aos meus queridos pais, José Rúbio (in memorium) e Elvira, com amor e admiração. 


\section{AGRADECIMENTOS}

À minha orientadora, Professora Edna Maria de Albuquerque Diniz, pela amizade e confiança, pelo estímulo, exemplo de pessoa e pesquisadora, apoio irrestrito ao longo destes anos e pelos ensinamentos constantes.

À Chefe da UCINE do Instituto da Criança do HCFMUSP, Professora Maria Esther Jurfest R. Ceccon, pela amizade, pelo carinho, incentivo e conhecimentos transmitidos durante a minha formação médica.

À Professora Thelma S. Okay e às profissionais do Laboratório de Investigação Médica (LIM-36) e do Laboratório do Instituto da Criança do HCFMUSP, Karina Kawasato, Lídia Yamamoto, Dra. Gilda Del Nigro e Maria Luisa, pela orientação da metodologia laboratorial e análise dos mediadores inflamatórios.

À equipe do Laboratório de Vírus Respiratórios do Serviço de Virologia do Instituto Adolfo Lutz de São Paulo, pela realização dos exames específicos para vírus respiratórios.

Ao Chefe do Laboratório de Virologia Clínica e Molecular do Instituto de Ciências Biomédicas II da USP, Professor Edison Durigon, pela realização dos exames moleculares para vírus respiratórios. 
Aos Médicos Assistentes da Unidade de Cuidados Intensivos Neonatal (UCINE) do Instituto da Criança do HCFMUSP, Dra. Marcília Sierro Grassi, Dra. Cristina Erico Yoshimoto, Dra. Meire Nagaiassu, Dr. Mário Cícero Falcão e Professor Rubens Feferbaum, pela amizade e pelo companheirismo durante a realização desta pesquisa.

Às fisioterapeutas, Lúcia Cândida Soares de Paula, Cristiane Ribeiro Afonso Fernandes e Milena Fernandes de Lima, pela amizade e pelo auxílio na coleta das secreções respiratórias dos pacientes.

Às enfermeiras da UCINE do Instituto da Criança do HCFMUSP, pelo coleguismo e carinho com que cuidam dos nossos pequenos pacientes.

À Ângela Paes Tavares, pelas sugestões e análise estatística deste trabalho.

À Mariza Kazue Umetsu da Biblioteca do Instituto da Criança do HCFMUSP, pela amizade, buscas bibliográficas e correção das referências da Tese.

Ao casal, Nivaldo L. e Milene Aparecida R. Rocha, pelo incentivo, pela amizade e elaboração dos exemplares. 
A todos recém-nascidos e seus pais ou responsáveis que participaram desta pesquisa e foram o motivo de sua realização. 


\section{NORMATIZAÇÃO ADOTADA}

Esta Tese está de acordo com as seguintes normas em vigor no momento desta publicação:

Referências: Adaptado de International Committee of Medical Journals Editors (Vancouver). Universidade de São Paulo. Faculdade de Medicina. Serviço de Biblioteca e Documentação. Guia de apresentação de dissertações, teses e monografias da FMUSP. Elaborado por Anneliese Carneiro da Cunha, Maria Júlia A.L. Freddi, Maria F. Crestana, Marinalva de S. Aragão, Suely C. Cardoso, Valéria Vilhena. $2^{\underline{a}}$ ed. São Paulo:Serviço de Biblioteca e Documentação;2005.

Abreviaturas dos títulos dos periódicos de acordo com List of Journals Indexed in Index Medicus. 
Resumo

Summary

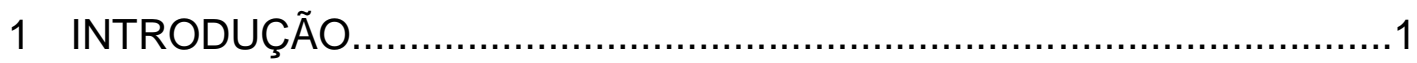

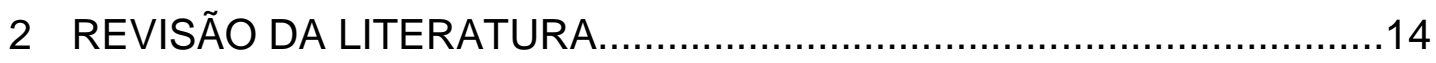

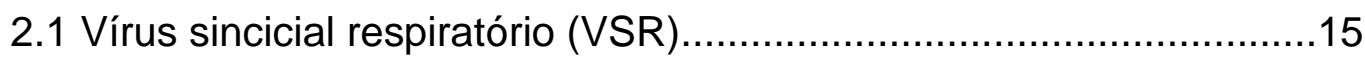

2.1.1 Considerações gerais.................................................................15

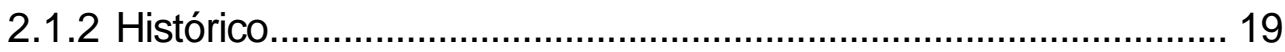

2.1.3 Classificação, estrutura e composição viral......................... 21

2.2 Infecção pelo VSR ........................................................ 23

2.3 Resposta do hospedeiro à infecção pelo VSR ........................... 25

2.3.1 Imunidade inata...................................................... 26

2.3.2 Imunidade adaptativa................................................ 30

2.4 Imunidade e patogênese da doença pelo VSR ......................... 34

2.4.1 Quimiocinas na infecção pelo VSR ................................... 36

2.4.2 Interações neuroimunes associadas à infecção

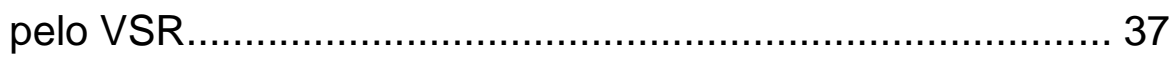

2.5 Perspectivas para prevenção e tratamento da infecção pelo VSR ........................................................................

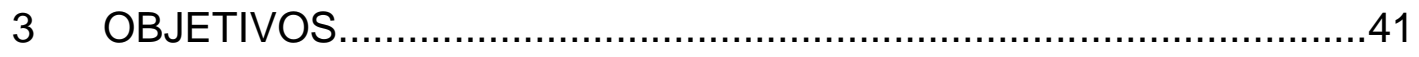

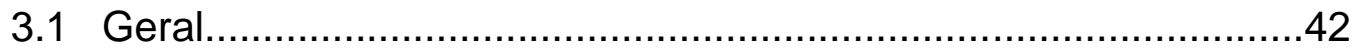

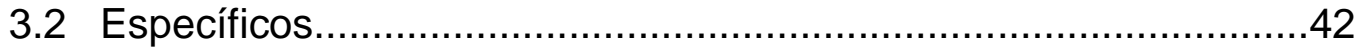

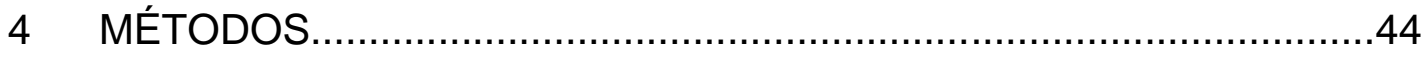

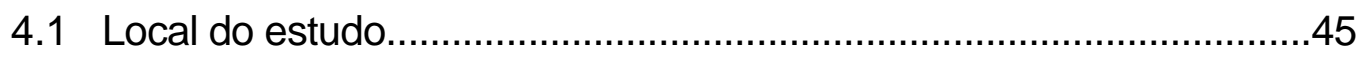

4.2 Critérios de inclusão e exclusão...................................................45

4.3 Coleta, transporte e processamento das amostras de secreção

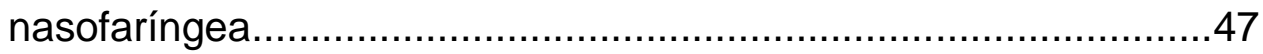

4.4 Exames específicos para vírus respiratórios...............................49 
4.4.1 Reação de imunofluorescência indireta..................................49

4.4.2 Isolamento em cultura celular.............................................51

4.4.3 Reação em cadeia da polimerase........................................52

4.5 Medida dos mediadores inflamatórios.........................................52

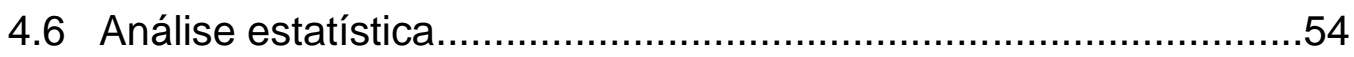

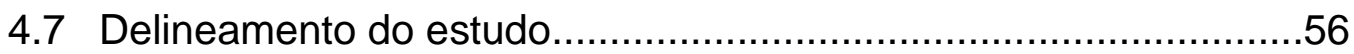

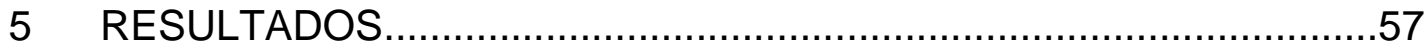

6 DISCUSSÃO

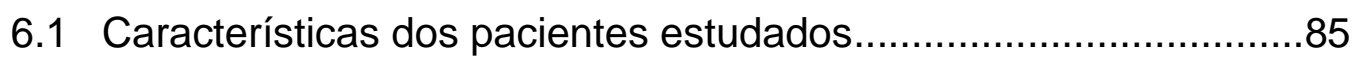

6.2 Correlação entre as concentrações dos mediadores inflamatórios nas primeiras, segundas e terceiras amostras de secreção nasofaríngea e soro e os marcadores clínicos de gravidade da ITRI

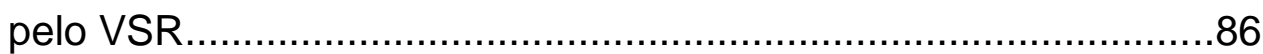

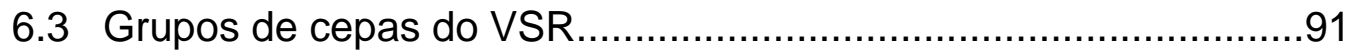

6.4 Comparação das concentrações dos mediadores inflamatórios na secreção nasofaríngea e no soro.

6.5 Comparação das concentrações dos mediadores inflamatórios na secreção nasofaríngea e soro, de acordo com as cepas dos grupos A e B do VSR.

6.6 Efeito do tempo de evolução da doença pelo VSR nas concentrações dos mediadores inflamatórios na secreção nasofaríngea e no soro e comparações múltiplas entre as concentrações dos mediadores inflamatórios.................................98

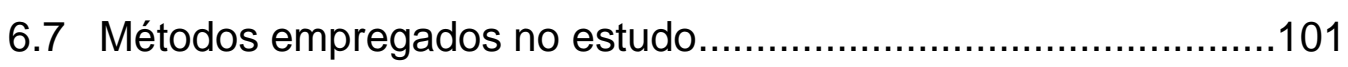

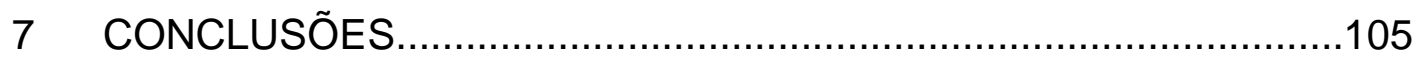

8 ANEXOS

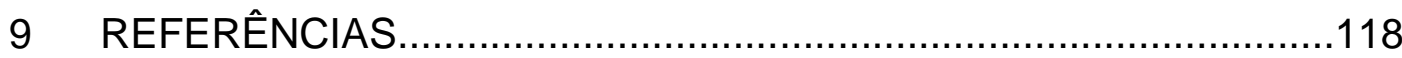


Vieira RA. Concentrações de mediadores inflamatórios em crianças com idade inferior a três meses e infecção do trato respiratório inferior pelo vírus sincicial respiratório [tese]. São Paulo: Faculdade de Medicina, Universidade de São Paulo; 2009. 151p.

INTRODUÇÃO: A elevada frequência e morbimortalidade das infecções do trato respiratório inferior (ITRI) pelo vírus sincicial respiratório (VSR) na infância, além da ausência de estudos no Brasil que correlacionam evolutivamente a resposta inflamatória no epitélio respiratório e no sangue periférico à gravidade da doença respiratória pelo VSR, estimularam a realização desta pesquisa. OBJETIVOS: Avaliar se as concentrações dos mediadores inflamatórios (MI) (RANTES, sICAM-1, TNF- $\alpha$, IL-6 e IL-10) e suas razões na secreção nasofaríngea e no sangue de crianças com idade inferior a 3 meses e ITRI pelo VSR correlacionamse à gravidade da doença; determinar a frequência dos grupos A e B do VSR nas crianças internadas na Unidade de Cuidados Intensivos Neonatal (UCINE) do Instituto da Criança do HCFMUSP; avaliar se há diferença na gravidade da doença respiratória pelo VSR entre as crianças internadas na UCINE e infectadas pelos grupos A e B do vírus; comparar as concentrações dos $\mathrm{MI}$ na secreção nasofaríngea e no sangue à admissão hospitalar ou por ocasião do diagnóstico de ITRI pelo VSR adquirida durante a internação, no terceiro e sétimo dias de evolução ou à alta (se antes do sétimo dia); comparar as concentrações dos MI na secreção nasofaríngea e no sangue dos pacientes à admissão, de acordo com grupos A e B do VSR; e descrever a evolução das concentrações de RANTES, sICAM-1, TNF- $\alpha$, IL-6 e IL-10 na secreção nasofaríngea e no sangue durante a doença pelo VSR. MÉTODOS: Foram incluídas no estudo prospectivo, de coorte, observacional, de julho de 2004 a dezembro de 2005, 30 crianças com idade inferior a três meses portadoras de ITRI pelo VSR internadas na UCINE. Foram medidas as concentrações dos MI na secreção nasofaríngea e no soro de todas as crianças à admissão no estudo, no terceiro e sétimo dias de evolução ou à alta hospitalar (se antes do sétimo dia) através da técnica ELISA sanduíche. Utilizamos para avaliar a gravidade da doença respiratória os seguintes marcadores clínicos: sistema de escore clínico modificado de De Boeck et al. (1997), tempos de oxigenoterapia e de ventilação mecânica e duração da internação. RESULTADOS: Houve correlação positiva significante entre a gravidade da doença pelo sistema de escore clínico modificado à admissão hospitalar e as concentrações na secreção nasofaríngea de sICAM-1 $(r=0,401, p=0,028)$ e IL-10 ( $r=0,412, p=0,024)$ e de IL-6 no soro $(r=0,469, p=0,009)$. Houve também correlação positiva significante entre as concentrações de IL-6 no soro e o tempo de oxigenoterapia $(r=0,445, p=0,023)$ e a duração da internação $(r=0,572, p=0,001)$. Das razões dos Ml estudadas, a IL-10/IL-6 (primeiras amostras de soro), a IL-6/TNF- $\alpha$ e a IL-6/IL-10 (segundas amostras de soro) foram associadas de forma mais consistente $(p<0,001)$ à gravidade da ITRI pelo VSR. Não ocorreram óbitos entre as crianças envolvidas 
neste estudo. Os dois grupos de VSR causaram ITRI nas crianças internadas na UCINE, sendo que o grupo A foi o mais frequente $(57 \%)$. No entanto, foram as crianças infectadas pelo grupo B do VSR as que evoluíram com maior morbidade $(p<0,001)$. As medianas das concentrações de RANTES, sICAM-1 e IL-10 foram maiores nas três amostras de soro $(p<0,001)$; enquanto as medianas das concentrações de IL-6 predominaram nas três amostras de secreção nasofaríngea $(p<0,001)$. A mediana das concentrações de TNF- $\alpha$ foi maior apenas nas primeiras amostras de secreção nasofaríngea $(p<0,001)$. Houve diferença estatisticamente significante entre os dois grupos do VSR apenas em relação à mediana das concentrações de IL-10 na secreção nasofaríngea à admissão hospitalar, que foi mais elevada nas crianças com infecção pelo grupo $B(p=0,039)$. As concentrações de RANTES, sICAM-1, IL-6 e IL-10 na secreção nasofaríngea e de TNF- $\alpha$, IL- 6 e IL-10 no soro variaram, de forma significante, durante a evolução da ITRI pelo VSR. Os demais níveis de MI na secreção nasofaríngea e no soro mantiveram-se estáveis durante o período de estudo. CONCLUSÕES: Níveis de RANTES, sICAM-1, TNF- $\alpha$, IL-6 e IL-10 foram detectados em todas as amostras de secreção nasofaríngea e de soro das crianças com ITRI pelo VSR internadas na UCINE, confirmando o papel destes MI na patogênese da doença. Nossos resultados sugerem que as concentrações de sICAM-1 e IL-10 na secreção nasofaríngea e IL-6 no soro à admissão, bem como as razões IL-10/L-6 (primeiras amostras de soro), IL-6/TNF- $\alpha$ e IL-6/L-10 (segundas amostras de soro), poderiam ser usadas como marcadores de gravidade da doença respiratória pelo VSR. Os níveis de IL-6 determinados no soro admissão também poderiam ser usados para predizer tempo de oxigenoterapia e duração da internação mais prolongados. Os grupos A e B do VSR cocircularam durante o período do estudo, com o grupo A sendo dominante nestes pacientes. Entretanto, foram as crianças infectadas com o grupo $B$ do vírus que evoluíram com maior morbidade. As concentrações de IL-10 na secreção nasofaríngea à admissão hospitalar foram significantemente maiores nos pacientes com ITRI pelo grupo B do VSR. O tempo de evolução da doença pelo VSR foi significante para os níveis de RANTES, sICAM-1, IL-6 e IL-10 na secreção nasofaríngea e de TNF- $\alpha$, IL-6 e IL-10 no soro destas crianças.

Descritores: 1.vírus sincicial respiratório; 2.bronquiolite; 3.pneumonia; 4.crianças; 5.mediadores da inflamação; 6.quimiocina CCL5; 7.molécula 1 de adesão intercelular; 8.interleucina-6; 9.interleucina-10; 10.fator de necrose tumoral alfa; 11 .pulmão/secreção; 12 .soro 
Vieira RA. Concentrations of inflammatory mediators in children less than three months of age with respiratory syncytial virus lower respiratory tract infection [thesis]. São Paulo: "Faculdade de Medicina, Universidade de São Paulo"; 2009. 151p.

INTRODUCTION: The high frequency and morbimortality of respiratory syncytial virus (RSV) lower respiratory tract infections (LRTI) in children, besides the lack of studies in Brazil that evolutionally correlate the inflammatory response in respiratory epithelium and in peripheral blood with RSV respiratory disease severity, have stimulated this research. OBJECTIVES: To assess whether the concentrations of inflammatory mediators (IM) (RANTES, sICAM-1, TNF- $\alpha$, IL-6 and IL-10) and their ratios in nasopharyngeal secretion and in blood of children less than 3 months of age and RSV LRTI correlate with disease severity; to determine the frequency of RSV groups A and B in children admitted to Unidade de Cuidados Intensivos Neonatal (UCINE) do Instituto da Criança do Hospital das Clínicas da Faculdade de Medicina da Universidade de São Paulo; to assess whether there is difference in RSV respiratory disease severity, according to RSV groups A and B; to compare the concentrations of IM in nasopharyngeal secretion and in blood at the time of hospital admission or by occasion of a diagnosis of RSV LRTI acquired during the stay, on third and seventh days of evolution or at the hospital discharge (should it had happened before the seventh day); to compare the concentrations of $\mathrm{IM}$ in nasopharyngeal secretion and in blood of patients at the hospital admission, according to RSV groups A and B; to describe the evolution of RANTES, sICAM-1, TNF- $\alpha$, IL- 6 and IL-10 concentrations in nasopharyngeal secretion and in blood. METHODS: Thirty children less than 3 months of age with RSV LRTI admitted to UCINE were included in the prospective cohort observational study, from July 2004 to December 2005. The concentrations of IM were measured through the sandwich ELISA technique in nasopharyngeal secretion and in serum of all children at the hospital admission, and on the third and seventh days of evolution or at the hospital discharge (if before the seventh day). We used the following markers to assess the severity of respiratory illness: the modified clinical scoring system by De Boeck et al. (1997), the days of oxygen supplementation and of mechanical ventilation and duration of hospitalization. RESULTS: There was a significant positive correlation between severity of disease by modified clinical scoring system at the time of hospital admission and nasopharyngeal secretion sICAM-1 $(r=0.401, p=0.028)$ and IL10 concentrations $(r=0.412, p=0.024)$ and serum IL-6 concentrations $(r=0.469$, $p=0.009$ ). There was also a significant positive correlation between serum IL-6 concentrations and the days of oxygen supplementation ( $r=0.572, p=0.001)$, as well as the days of hospital stay $(r=0.572, p=0.001)$. Of IM ratios studied, IL10/L-6 (first samples of serum), IL-6/TNF- $\alpha$ and IL-6/L-10 (second samples of serum) were associated to severity of RSV LRTI with greatest consistency $(p<0.001)$. No fatal cases occurred among the children enrolled in this study. The 
two groups of RSV caused LRTI in 30 children less than 3 months of age hospitalized in UCINE, being group $A$ the most frequent (57\%). However, the children infected by RSV group B were the ones that evolved with a greater need of mechanical ventilation $(p<0.001)$. Medians RANTES, sICAM-1 and IL-10 concentrations were greater in all the three serum samples $(p<0.001)$; whereas medians IL- 6 concentrations were predominant in the three nasopharyngeal secretion samples $(p<0.001)$. Median TNF- $\alpha$ concentration was greater only in the first nasopharyngeal secretion samples $(p<0.001)$. There was a statistically significant difference between the two groups of RSV only relative to the median IL-10 concentrations on first nasopharyngeal secretion samples, which was more elevated in children infected by RSV group $B(p=0.039)$. The nasopharyngeal secretion RANTES, sICAM-1, IL-6 and IL-10 and serum TNF- $\alpha$, IL-6 and IL-10 concentrations varied significantly during the evolution of RSV LRTI. The other nasopharyngeal secretion and serum IM levels remained stable during the period of study. CONCLUSIONS: Levels of RANTES, sICAM-1, TNF- $\alpha$, IL- 6 and IL-10 were detected in all nasopharyngeal secretion and serum samples of children with RSV LRTI admitted to UCINE, therefore confirming the role of these IM in pathogenesis of illness. Our results suggest that nasopharyngeal secretion sICAM-1 and IL-10 and serum IL-6 concentrations determined at hospital admission, as well as the ratios IL-10/IL-6 (first samples of serum), IL-6/TNF- $\alpha$ and IL-6/IL-10 (second samples of serum), could be used as markers of RSV respiratory disease severity. The levels of IL-6 found in serum at the time of hospital admission could also be used to predict prolonged oxygen supplementation and hospital stay. RSV groups A and B co-circulated during the period of the study, with group A being dominant in these patients. However, the children infected by RSV group B were the ones that evolved with a greater morbidity. Nasopharyngeal secretion IL-10 concentrations at admission were significantly greater in patients with RSV group B LRTI. The duration of RSV disease evolution was significant to nasopharyngeal secretion RANTES, sICAM1, IL-6, IL-10 levels and to serum TNF- $\alpha, \mathrm{IL}-6$ and IL-10 concentrations of these children.

Descriptors: 1.respiratory syncytial virus; 2.bronchiolitis; 3.pneumonia; 4.children; 5.inflammation mediators; 6.chemokine CCL5; 7.intercellular adhesion molecule-1; 8.interleukin-6; 9.interleukin-10; 10.tumor necrosis factoralpha; 11.lung/secretion; 12.serum 
1

INTRODUÇÃO 


\section{INTRODUÇÃO}

As infecções do trato respiratório inferior (ITRI) pelo vírus sincicial respiratório (VSR) constituem uma das patologias mais frequentes e graves nos primeiros meses de vida, principalmente nas crianças com idade inferior a seis semanas e naquelas que são pré-termo, sendo consideradas uma das causas mais importantes de mortalidade nesta faixa etária nos países desenvolvidos (Berman, 1991; Tirado et al., 1995). Aproximadamente 50 crianças por ano com ITRI, bronquiolite e/ou pneumonia, são admitidas na Unidade de Cuidados Intensivos Neonatal (UCINE) do Instituto da Criança do Hospital das Clínicas da Faculdade de Medicina da Universidade de São Paulo (HCFMUSP), principalmente nos meses de outono e inverno.

Tem sido observado uma grande variação no quadro clínico de cada paciente, independente do grupo de cepa (A ou B) do VSR e dos polimorfismos do vírus, indicando neste processo a importância de fatores próprios do hospedeiro como menor calibre das vias aéreas intrapulmonares, predisposição atópica, imaturidade ou alteração das imunidades inata e adaptativa, cardiopatias congênitas cianogênicas e displasia broncopulmonar (Arruda Neto et al., 2006; Brandenburg et al., 2000). Na infecção primária pelo VSR, o pico da doença não coincide com o pico da replicação viral, mas com o desenvolvimento das respostas específicas das células $\mathrm{T}$ e $\mathrm{B}$ ao vírus, o que demonstra ser a resposta imune a responsável, em grande parte, pela doença respiratória (Openshaw, 2005). 
Nas ITRI, a inflamação local é causada pelo efeito citopático do VSR nas células epiteliais das vias aéreas e pelas reações inflamatórias sistêmicas do hospedeiro. Em geral, o ponto inicial de contato do VSR com o hospedeiro é o epitélio nasal, que funciona como barreira física, além de ter papel fundamental na imunidade inata pela elevação de uma variedade de mediadores inflamatórios. A imunidade inata ou natural, já desenvolvida no período neonatal, tem a função de conter a patogênese da doença e é composta pelas respostas humoral (proteínas de fase aguda, sistema complemento e citocinas) e celular (monócitos, macrófagos, neutrófilos, células dendríticas e células Natural Killer (NK)), que deflagram a imunidade adaptativa ou adquirida, ainda não estabelecida no início da vida (Krishnan et al., 2003). A imunidade adaptativa promove a secreção de citocinas pelas células T, o aumento da síntese de citocinas anti-inflamatórias, a redução de receptores das citocinas e a liberação de antagonistas dos receptores das citocinas (Ogra, 2004; Tripp, 2004).

Alguns autores sugerem que a ITRI pelo VSR é mais grave no período neonatal, devido à síntese elevada de interferon-alfa (IFN- $\alpha$ ) (citocina antiviral capaz de suprimir as respostas das células mononucleares) nesta fase da vida, à falta de expressão do fator regulador de interferon-1 (IFN-1) e à suspeita hiporresponsividade da imunidade inata (Krishnan e Halonen, 2007).

As citocinas, denominadas hormônios do sistema imune, são proteínas sintetizadas e secretadas em resposta a algum estímulo por células dos sistemas imunológico e não-imunológico. Constituem 
glicoproteínas ou polipeptídeos que atuam, em quantidades mínimas, através da ligação a receptores celulares específicos. Têm como uma das principais funções a comunicação intercelular e são inibidas por corticosteroides e outros imunossupressores. Polimorfismos em determinados genes que coordenam a síntese das citocinas e variações genéticas nos seus receptores podem contribuir para a maior frequência e gravidade da doença pelo VSR (Gentile et al., 2003; Haddad, 2002; Hull et al., 2003).

Podem ser classificadas em citocinas pró-inflamatórias (produzidas inicialmente em resposta a um processo inflamatório) e anti-inflamatórias (ocorrem posteriormente à produção das citocinas pró-inflamatórias). As principais citocinas pró-inflamatórias são: fator de necrose tumoral-alfa/beta (TNF- $\alpha / \beta$ ), interleucina-1alfa/beta (IL-1 $\alpha / \beta)$, interleucina-2 (IL-2), interleucina6 (IL-6), interleucina-8 (IL-8), interleucina-12 (IL-12), interleucina-17 (IL-17), interleucina-18 (IL-18) e Regulated upon Activation, Normal T-cell Expressed and presumably Secreted (RANTES). Estas citocinas quando entram na circulação sistêmica produzem ativação de células imunes e alterações significativas na fisiologia do hospedeiro, como febre e reação de fase aguda. Uma produção excessiva das citocinas pró-inflamatórias pode resultar em dano do epitélio respiratório e/ou sistêmico. As citocinas antiinflamatórias são: interleucina-4 (IL-4), interleucina-10 (IL-10), interleucina-13 (IL-13) e fator transformador de crescimento-beta (TGF- $\beta$ ). A resposta antiinflamatória ocorre paralelamente à síntese das citocinas pró-inflamatórias e 
uma resposta exacerbada das citocinas anti-inflamatórias pode levar à imunossupressão (Kilpatrick e Harris, 2004).

Estudos in vitro e em crianças com infecção pelo VSR demonstram que as células epiteliais das vias aéreas e os macrófagos alveolares produzem diversos mediadores inflamatórios, como: prostaglandinas; leucotrienos; citocinas (interferons antivirais alfa/beta (IFN- $\alpha / \beta)$, TNF- $\alpha$, IL$1 \beta$, IL-2 e IL-6); quimiocinas, que são citocinas com função quimiotática (IL8, RANTES, proteína quimiotática monocitária tipo 1 (MCP-1) e proteína inflamatória macrofágica tipo 1 alfa/beta (MIP-1 $1 \alpha / \beta))$; moléculas de adesão (moléculas de adesão intercelular tipo 1 (ICAM-1), molécula de adesão da célula vascular tipo 1 (VCAM-1), molécula de adesão endotelial tipo 1 (ELAM-1) e E-selectina); e outras proteínas imunomodulatórias, entre elas os fatores de crescimento (granulocyte macrophage-colony stimulating factor (GM-CSF) e granulocyte-colony stimulating factor (G-CSF)) (Abbas e Lichtman, 2005; Mariscalco, 2004).

O TNF- $\alpha$ e a IL-1 $\beta$, expressos pelas células epiteliais respiratórias infectadas pelo VSR, ativam a cascata de citocinas pró-inflamatórias e promovem o recrutamento e a migração de tipos específicos de leucócitos (monócitos, neutrófilos e linfócitos) aos tecidos afetados. A ativação destas células inflamatórias dá início à produção de novas citocinas pró e antiinflamatórias (McNamara e Smyth, 2002).

As interleucinas IL-12 e IL-18 induzem as células T e NK a produzir interferon-gama (IFN-ץ). O IFN-ฯ promove a diferenciação das células $\mathrm{T}$ $\mathrm{CD}^{+}$em células T-helper tipo 1 (Th1), que produzem citocinas Th1 (TNF- $\alpha$, 
IFN-ץ, IL-2 e IL-12). O IFN-ץ também inibe a diferenciação das células T $\mathrm{CD}^{+}$em células T-helper tipo 2 (Th2), que sintetizam citocinas Th2 (IL-4, interleucina-5 (IL-5), IL-6, IL-13 e IL-17), as quais são inibidoras das citocinas Th1. O desbalanço entre as citocinas Th1 e Th2, com predomínio das Th2, que ocorre nos quadros mais graves de infecção pelo VSR, pode aumentar o risco de hiper-reatividade das vias aéreas e sibilância futura no período pós-bronquiolite pelo VSR (Boelen et al., 2002; Durbin et al., 2002). As mudanças imunológicas observadas nas crianças com doença grave pelo VSR podem ser parcialmente explicadas pelo aumento dos níveis do cortisol plasmático (Pinto et al., 2006).

A produção de citocinas pró e anti-inflamatórias, moléculas de adesão celular e outras proteínas imunomoduladoras pode ser menor nos recém-nascidos (RN), principalmente nos pré-termo, do que nos adultos, fator este que limita a resposta imune ao VSR no período neonatal (Boukhvalova et al., 2007; Chung et al., 2007; Queiróz et al., 2002).

As respostas pró e anti-inflamatórias baseiam-se na síntese de mediadores que autorregulam-se durante a inflamação. Os mediadores inflamatórios são produzidos por diversos tipos de células imunes e têm muitas atividades biológicas que auxiliam na coordenação das respostas do organismo contra a infecção pelo VSR, como descrito a seguir:

\section{RANTES}

A RANTES é uma citocina quimiotática, com peso molecular de 8 a 12 $\mathrm{kDa}$, cujo principal papel é recrutar células inflamatórias para os locais com infecção (Kawasaki et al., 2006). A RANTES recruta eosinófilos, neutrófilos, 
monócitos, linfócitos $\mathrm{T}$ auxiliares e macrófagos para os locais com inflamação, o que leva à adesão dos leucócitos ao epitélio pulmonar já lesado pela ação viral e à sua posterior desgranulação, com aumento do dano tecidual (Jaovisidha et al., 1999; McNamara e Smyth, 2002). As principais células produtoras de RANTES são os macrófagos, células epiteliais e endoteliais, linfócitos $T$, fibroblastos, eosinófilos e plaquetas (Olszewska-Pazdra et al., 1998). A síntese de RANTES aumenta nas doenças pulmonares e sua produção menor no período neonatal pode sugerir uma resposta pior às infecções, devido à deficiência na quimiotaxia (Kilpatrick e Harris, 2004). Tem sido relatado que níveis elevados de RANTES nas secreções respiratórias durante a infecção pelo VSR poderiam predizer o desenvolvimento tardio de sibilância recorrente (Chung e Kim, 2002; Legg e Johnston, 2002).

\section{ICAM-1}

As ICAM-1 podem ser encontradas tanto na forma de glicoproteínas transmembranas (mICAM-1), com peso molecular de $90 \mathrm{kDa}$, que auxiliam no trânsito de células imunes, quanto solúveis (sICAM-1) na secreção respiratória, soro e líquor. As citocinas inflamatórias (TNF- $\alpha$, IFN-Y e IL-1) aumentam a expressão das ICAM-1 pelas células epiteliais e endoteliais, linfócitos, monócitos e eosinófilos, além de ativar seus receptores, integrinas LFA-1 e Mac-1, nos neutrófilos; enquanto os agentes anti-inflamatórios (glicocorticoides) reduzem sua expressão. Os mecanismos de migração dos neutrófilos para o lúmen das vias aéreas são cruciais para o desenvolvimento da lesão do epitélio respiratório na bronquiolite aguda e 
são mediados pelas moléculas de adesão. As ICAM-1 mediam a adesão dos leucócitos às células que as expressam, um passo essencial para a migração de novos leucócitos ao epitélio pulmonar inflamado (Duperray et al., 1997).

\section{TNF- $\alpha$}

O TNF- $\alpha$ é o mediador principal da resposta inflamatória aguda a diversos microrganismos, inclusive o VSR, e é responsável por muitas complicações sistêmicas das infecções graves. Age na contenção da infecção local, mas sua liberação exacerbada e prolongada está associada à gravidade da doença. A molécula de TNF- $\alpha$ pesa $17 \mathrm{kDa}$ e os seus maiores produtores são os macrófagos, seguidos pelas células $T$ antígenoestimuladas, células NK, células epiteliais e pelos mastócitos (Abbas e Lichtman, 2005). A glicoproteína SH (small hydrophobic) do VSR tem a função de inibir a produção de TNF- $\alpha$ pelas células epiteliais infectadas (Fuentes et al., 2007).

Entre as funções mais importantes do TNF- $\alpha$ estão: o recrutamento de neutrófilos e monócitos; a formação de moléculas de adesão, que são essenciais para a adesão dos leucócitos à superfície endotelial e posterior migração para o trato respiratório infectado pelo VSR; a ativação das células inflamatórias, com expressão de outras citocinas pró-inflamatórias para a erradicação do vírus; o estímulo à migração de células dendríticas aos linfonodos, com maturação das mesmas e início da imunidade adaptativa; a síntese de proteínas de fase aguda pelo fígado, que ativam o sistema complemento e induzem à opsonização; e a ação no hipotálamo, como 
pirógeno endógeno, levando à febre, que pode reduzir a replicação viral e aumentar a resposta imune específica (Abbas e Lichtman, 2005).

\section{IL-6}

A molécula de IL-6 pesa entre 19 e 26 kDa e a sua produção por macrófagos, monócitos, células epiteliais e endoteliais e células Th2 é estimulada pelo TNF- $\alpha$, pela IL-1 e pelas células T (Abbas e Lichtman, 2005)

A IL-6 inibe a produção de TNF- $\alpha$ e IL-1 nas células mononucleares do sangue periférico e tem a capacidade de estimular a produção dos antagonistas dos receptores do TNF (TNF-Ra) e da IL-1 (IL-1Ra), com redução da extensão da inflamação nas vias aéreas produzida pelo VSR. Deste modo, a IL-6 tem sido classificada também como uma citocina antiinflamatória. Inicialmente, a atividade da IL-6 ocorre no local de produção, como os sítios das células inflamatórias, promovendo a ativação dos linfócitos, neutrófilos e macrófagos, com posterior regulação dos efeitos sistêmicos nos órgãos alvo. No fígado, promove a síntese das proteínas de fase aguda da inflamação. Induz tanto a proliferação das células $B$, com acentuação da produção de imunoglobulinas $G, M$ e A (lgG, $\lg M$ e $\lg A)$ e aumento da resposta secundária dos anticorpos aos antígenos, quanto a resposta das células Th, linfócitos T citotóxico e células NK. A IL-6 é conhecida como a principal citocina que inicia a resposta de fase aguda da inflamação. A análise de IL-6 como marcador inflamatório tem mostrado correlação com outros índices de atividade das doenças, e pode ser usada em associação com outros testes diagnósticos. Níveis de IL-6 
persistentemente elevados estão associados à gravidade do quadro infeccioso (Hornsleth et al., 1998; McNamara e Smyth, 2002).

\section{IL-10}

A IL-10, com peso molecular entre 34 e $40 \mathrm{kDa}$, é secretada pelos macrófagos e células $T$ regulatórias e sua síntese aumenta com estímulos variáveis, como TNF- $\alpha$, IL-1, IL-6 e IL-12 (Hawrylowicz, 2005).

O papel da IL-10 na infecção pelo VSR é controverso. Apresenta vários efeitos biológicos possíveis, como: inibição da função dos macrófagos com consequente inibição da produção de citocinas pró-inflamatórias (IFN-r, TNF- $\alpha$, IL-1, IL-4, IL-6, IL-8 e RANTES), moléculas de adesão, fatores de crescimento e da própria IL-10, e supressão de uma resposta imune efetiva ao VSR; estimulação da produção do IL-1Ra, que tem atividade antiinflamatória; inibição da replicação viral; atividade imunoestimulante pelo aumento da função das células B; e estimulação do desenvolvimento de células T citotóxicas (Beishuizen et al., 1999).

Bont et al. (2000) relatam que há associação entre níveis aumentados de IL-10 durante a infecção aguda pelo VSR e sibilância pós-bronquiolite. Justice et al. (2001) e Mäkelä et al. (2002), em modelos animais para o estudo da asma, constatam que a IL-10 contribui para a hiper-reatividade das vias aéreas. Enquanto Chung et al. (2005) e Murai et al. (2007) não encontram correlação entre asma ou sibilância recorrente e concentrações mais elevadas de IL-10 durante a infecção pelo VSR, demonstrando assim que fatores múltiplos podem estar envolvidos no desenvolvimento da asma ou sibilância recorrente pós-infecção pelo VSR. 
A neutralização da IL-10 com anticorpo monoclonal específico (anti-IL10) resulta em níveis elevados de TNF- $\alpha$ e maior mortalidade em animais experimentais com sepse (Moore et al., 1993). Em estudo animal, a administração, em bolo, de IL-10 reduz a capacidade antigênica dos monócitos e a resposta das citocinas pró-inflamatórias, protegendo contra a mortalidade (Romagnoli et al., 2001). No entanto, níveis elevados de IL-10 são correlacionados à maior gravidade das doenças infecciosas. A produção adequada de $\mathrm{IL}-10$ parece ser protetora nos processos inflamatórios/infecciosos (Murai et al., 2007).

A elevação destes mediadores inflamatórios tem um efeito significante tanto na resposta inflamatória inicial como nos eventos imunológicos tardios. Algumas pesquisas têm constatado correlação positiva (Hornsleth et al., 2001) ou negativa (Sheeran et al., 1999) significante entre as concentrações de certos mediadores inflamatórios nas secreções respiratórias e a gravidade da doença pelo VSR, porém outras não conseguem demonstrar qualquer tipo de correlação (Chung e Kim, 2002; Giugno et al., 2004).

A maioria dos estudos avaliam as concentrações dos mediadores inflamatórios nas secreções respiratórias apenas no momento do diagnóstico da doença pelo VSR, sem entretanto demonstrar o comportamento evolutivo destes mediadores inflamatórios (Giugno et al., 2004; Hornsleth et al., 2001; Sheeran et al., 1999). Além disto, estas pesquisas utilizam casuística com grande variação de idade (de 0 a 51 meses) e de tempo de doença respiratória à avaliação dos mediadores inflamatórios, fatores que podem interferir na análise dos mediadores 
inflamatórios. Os mesmos estudos também não correlacionam evolutivamente as concentrações dos mediadores inflamatórios na secreção respiratória à gravidade da doença pulmonar. Os trabalhos publicados até o momento questionam se os valores dos mediadores inflamatórios medidos no sangue poderiam ser correlacionados à gravidade da infecção pulmonar pelo VSR, e como seria o comportamento destes mediadores no sangue durante a evolução da doença respiratória (Legg e Johnston, 2002; Legg et al., 2003). Justifica-se deste modo a necessidade de novos estudos para elucidar a resposta das citocinas nas vias aérea e sistêmica das crianças com idade inferior a 3 meses durante a infecção pelo VSR. O conhecimento da resposta imunológica à infecção pelo VSR poderá auxiliar na condução clínica dos pacientes, além da possibilidade de ser utilizado no desenvolvimento de novas terapêuticas imunomodulatórias, ou seja, antagonistas dos receptores das citocinas pró-inflamatórias (Gern e Busse, 2000).

Tendo em vista a frequência e a morbimortalidade elevadas das infecções pulmonares pelo VSR na infância e a importância dos mediadores inflamatórios RANTES, sICAM-1, TNF- $\alpha$, IL-6 e IL-10 na gênese dos processos inflamatórios/imunes, além da ausência de estudos correlacionando evolutivamente a resposta inflamatória do hospedeiro (na secreção respiratória e no sangue) à gravidade da doença respiratória pelo VSR, é que decidimos realizar uma pesquisa para avaliar o papel destes mediadores inflamatórios na patogênese da ITRI pelo VSR nos três primeiros meses de idade. 
Hipótese: Considerando o comportamento diferente destes mediadores inflamatórios durante a infecção pelo VSR, acredita-se que estas substâncias possam ser utilizadas como marcadores de gravidade da ITRI. 
2

REVISÃO DA LITERATURA 


\section{REVISÃO DA LITERATURA}

\subsection{Vírus sincicial respiratório (VSR)}

\subsubsection{Considerações gerais}

Nas últimas 4 décadas houve um grande aumento do conhecimento a cerca da etiologia das infecções respiratórias, sendo destacado o papel dos vírus na gênese de infecções, tanto do trato respiratório superior como inferior. O desenvolvimento de novas técnicas diagnósticas para os vírus respiratórios, bem como o aprimoramento daquelas já existentes, facilitou a realização de estudos epidemiológicos sobre o VSR (Hemming, 1994).

O VSR é o patógeno viral mais importante do trato respiratório inferior em crianças com idade inferior a 3 anos. O período anual da epidemia do VSR pode variar de acordo com o clima de cada localidade. Em São Paulo, de clima subtropical, o pico ocorre no outono e estende-se ao inverno, podendo o VSR ser isolado durante o ano todo (Diniz et al., 2005; Vieira et al., 2002). O período de incubação do VSR é geralmente de 2 a 8 dias (média de 5 dias) e a excreção viral pode ocorrer desde alguns dias antes do início dos sintomas e persistir por semanas em certos pacientes com alterações imunitárias e em portadores de doenças de base. Este vírus é responsável por 50 a $90 \%$ dos casos de bronquiolite e por aproximadamente $50 \%$ de todas as pneumonias (Filippel e Rearick, 1993).

Cerca de 50 a $70 \%$ dos lactentes são infectados pelo VSR no primeiro ano de vida e quase $100 \%$ das crianças se infectam entre os 2 e 3 anos de 
idade; $50 \%$ das crianças infectadas se reinfectam, sugerindo que a infecção natural não produz imunidade permanente (Holberg et al., 1991).

A doença pelo VSR tem duração média de 7 a 12 dias e nas crianças com idade inferior a 6 semanas pode simular quadro de sepse bacteriana em 25 a 50\% dos casos (Filippell e Rearick, 1993; Frankel e Derish, 1999; Miyao et al., 1999; Vieira et al., 2003; Diniz et al., 2005).

Alguns fatores de suscetibilidade e de exposição podem aumentar a incidência e a gravidade da doença respiratória pelo VSR, como: prematuridade; displasia broncopulmonar; cardiopatia congênita (cianogênica ou não) com repercussão hemodinâmica; doenças metabólicas, genéticas ou imunológicas; malformações anatômicas; doenças neuromusculares; história familiar de atopia; desnutrição; nascimentos múltiplos; nascimento nos 6 meses que antecedem a estação do VSR; ausência de aleitamento materno; aglomerações de pessoas, inclusive domicílio populoso, creches e transportes públicos, nos meses mais frios e secos; poluição ambiental; tabagismo passivo; nível baixo socioeconômico e de instrução materna; irmãos em idade escolar; e hospitalizações prolongadas durante a sazonalidade do vírus (Meissner et al., 1996; Meissner et al., 1999; Stretton et al., 1992; Tissing et al., 1993).

Das crianças previamente saudáveis infectadas pelo VSR no primeiro ano de vida, 15 a 22\% desenvolvem ITRI, com taxa de hospitalização variando entre 0,5 e $2 \%$. A mortalidade entre estes pacientes hospitalizados pode variar de 0,5 a $3,5 \%$. Dez a $25 \%$ das crianças prematuras com idade gestacional menor ou igual a 32 semanas e displasia broncopulmonar que 
adquirem infecção pelo VSR necessitam de hospitalização, sendo que a mortalidade neste grupo pode variar de 35 a 50\% (Cunningham et al., 1991; Wang et al., 1995).

As crianças pré-termo com infecção pelo VSR apresentam, com maior frequência, apneia, atelectasias, necessidade de rehospitalização e de ventilação mecânica, além de internações mais prolongadas (Forster et al., 1995; Meert et al., 1990). Os pré-termos são mais predispostos a adquirir infecção respiratória viral devido à imaturidade do sistema imunológico e baixa concentração de anticorpos neutralizantes específicos para o VSR, de transmissão materna passiva para o feto, principalmente no terceiro trimestre da gestação. Durante o primeiro ano de vida, a partir dos 6 meses de idade, constata-se um declínio gradual na concentração dos anticorpos anti-VSR transmitidos passivamente à criança através da placenta e do leite materno (a duração média dos anticorpos maternos é estimada em 3,3 meses) (Cox et al., 1998). A infecção pelo VSR pode associar-se a complicações a curto e longo prazo como sibilância recorrente, hiperrreatividade de vias aéreas e anormalidades da função pulmonar (Openshaw et al., 2003; Stein e Martinez, 1997).

Vários mecanismos tem sido propostos para explicar a associação da infecção pelo VSR à hiper-reatividade brônquica e à sibilância, como: presença de neuropeptídeos e aumento da expressão de seus receptores específicos; liberação de leucotrienos e outros metabólitos celulares; ativação de mastócitos e eosinófilos; produção de imunoglobulina E (IgE); substituição para ou persistência das respostas celulares Th2; 
desenvolvimento de citocinas pró-inflamatórias ou imunorregulatórias. Podese incluir entre os mecanismos que contribuem para a hiper-reatividade brônquica secundária à infecção pelo VSR a restrição anatômica da árvore brônquica nos primeiros meses de vida e o dano tecidual causado pela própria infecção. Durante a infecção aguda viral, o epitélio respiratório fica exposto a receptores irritantes ativados, que induzem à estimulação neurogênica da musculatura lisa brônquica e ao espasmo brônquico. Os fatores neurogênicos são mais importantes na indução da hiper-reatividade brônquica no início da infância devido à anatomia das vias aéreas nesta faixa etária (Ogra, 2004).

Infecções bacterianas secundárias muitas vezes complicam as infecções virais, mas os mecanismos para que os vírus predisponham a doenças bacterianas não está completamente esclarecido. Avadhanula et al. (2006) sugerem que a infecção pelo VSR aumenta a expressão de receptores para Streptococcus pneumoniae e Haemophylus influenzae nas células epiteliais brônquicas primárias, facilitando a colonização e a doença bacteriana.

A disseminação do VSR ocorre por auto-inoculação após toque em superfícies não porosas contaminadas com secreções, nas quais o vírus pode sobreviver de 4 a 7 horas, ou por inoculação direta de gotículas nos olhos e nariz. Existem vários procedimentos eficazes para se prevenir a infecção nosocomial em berçários, tais como a lavagem de mãos e o uso de aventais, luvas, máscaras, gorros e óculos que protejam os olhos e o nariz (Madge et al., 1992; Okuonghae et al., 1992; Wright et al., 1993). 
Ainda não está disponível para uso em humanos uma vacina que seja segura e eficaz contra o VSR. Estudos em modelos animais têm auxiliado no desenvolvimento de vacinas e tratamentos, e no melhor entendimento do balanço entre imunidade e patogênese da doença associada à infecção pelo VSR.

\subsubsection{Histórico}

Morris et al., em 1956, notam sinais de resfriado comum em uma colônia de 14 chimpanzés, que são observados por três a 24 semanas. Um novo vírus é isolado dos chimpanzés e recebe o nome de agente da coriza do chimpanzé (CCA). Funcionários que trabalham com os animais adquirem sinais e sintomas similares de resfriado comum, mas menos intensos do que os dos chimpanzés, e o anticorpo para o CCA é identificado nos animais infectados, confirmando suas doenças (Morris et al., 1956).

No ano seguinte, Chanock et al. isolam um vírus indistinguível do CCA em duas crianças com infecção respiratória. São identificadas duas cepas diferentes, a cepa Long é isolada no lavado broncoalveolar de uma criança com broncopneumonia e a cepa Schneider é recuperada na secreção respiratória de outra com crupe. O agente é renomeado de vírus sincicial respiratório (VSR), baseado em seu efeito citopático que caracteriza-se pela formação de sincícios em meio de cultura. Os autores descrevem a apresentação clássica da doença respiratória causada pelo VSR em crianças (Chanock et al., 1957b).

Ainda em 1957, Chanock e Finberg estudam a elevação de anticorpos séricos a este vírus em pacientes com doença respiratória e notam que $80 \%$ 
das crianças aos 4 anos de idade possuem anticorpos neutralizantes contra o VSR (Chanock et al., 1957a).

Candeias (1967) publica o primeiro artigo brasileiro sobre o VSR. São estudadas 24 crianças com quadro respiratório agudo internadas no Hospital Infantil Menino Jesus de São Paulo, em agosto de 1964, das quais coleta-se material das mucosas nasal e nasofaríngea utilizando swabs. O VSR é isolado de quatro pacientes (uma criança com pneumonia e desnutrição de 3 meses de idade; duas com bronquiolite e pneumonia, sendo uma delas de 3 dias de vida e a outra de 3 meses; e uma com pneumonia de 45 dias de idade). A confirmação do isolamento em cultura de células é obtida através da prova de neutralização com soro padrão (Candeias, 1967).

No Brasil, os primeiros estudos para determinação da importância das infecções virais do trato respiratório inferior no período neonatal são os publicados por Vieira et al. (2003) e Diniz et al. (2005).

Vieira et al. (2003) determinam a prevalência de ITRI pelos vírus respiratórios em $90 \mathrm{RN}$ com diagnóstico de bronquiolite e/ou pneumonia à admisão na UCINE do Instituto da Criança-HCFMUSP, durante o período de janeiro de 1999 a janeiro de 2001. São identificados vírus respiratórios em 72 RN (80\%), sendo o VSR $(44,4 \%)$ o mais prevalente, seguido pelo vírus influenza A (22,2\%) (Vieira et al., 2003).

Diniz et al. (2005) verificam a incidência de infecção pelos vírus respiratórios em $78 \mathrm{RN}$ pré-termo com insuficiência respiratória aguda submetidos à ventilação mecânica e internados na UCINE no período de novembro de 2000 a setembro de 2002. Os autores diagnosticam vírus 
respiratórios em 23 crianças, sendo o VSR (14,1\%) o mais frequente (Diniz et al., 2005).

\subsubsection{Classificação, estrutura e composição viral}

O VSR pertence à família Paramyxoviridae, subfamília Pneumovirinae e ao gênero Pneumovírus (Hall, 1998). É um vírus encapsulado, pleomórfico, medindo entre 150 e 300nm de diâmetro, cujo genoma consiste de uma fita única de RNA não segmentado com polaridade negativa, contendo 15.222 nucleotídeos. O genoma viral codifica 11 proteínas denominadas não estruturais (NS1 e NS2), proteína do nucleocapsídeo (N), fosfoproteína (P), matriz (M1 e M2-1), matriz secundária (M2-2), glicoproteínas de superfície: G (adsorção), F (fusão) e SH, e RNA dependente da RNA polimerase (L). O nucleocapsídeo viral tem simetria helicoidal, com tamanho médio de $13,5 \mathrm{~nm}$, e é formado pelas proteínas da matriz do virion e proteínas $\mathrm{N}, \mathrm{P}$ e $\mathrm{L}$ associadas ao genoma RNA. O envelope lipídico que envolve o nucleocapsídeo é derivado da membrana citoplasmática da célula hospedeira durante o processo de brotamento do VSR e contém as três glicoproteínas de superfície (G, F e SH) (Marty et al., 2004).

É descrito que das proteínas do VSR, quatro têm papel imunológico. As proteínas $\mathrm{N}$ e M2 parecem induzir proteção transitória pela estimulação de linfócitos T citotóxicos e as glicoproteínas de superfície F e G são as mais importantes nos processos infecciosos e imunológicos. A glicoproteína F é responsável pela fusão do envelope viral à membrana plasmática da célula hospedeira e atua como mediadora da fusão de uma célula infectada a uma 
adjacente, levando à formação de sincícios. Promove a formação de anticorpos contra o VSR. Já a glicoproteína G está envolvida com a ligação do vírus ao receptor celular durante os estágios iniciais do ciclo infeccioso. Induz a resposta citotóxica ao vírus (Sullender, 2000).

As cepas do VSR são as mesmas em todo o mundo e estão classificadas em dois grupos distintos (A e B), que podem circular simultaneamente no mesmo surto sazonal e causar infecção concomitante. Em geral, a imunidade parcial conferida a um grupo de cepas não garante imunidade ao outro grupo. No entanto, alguns estudos mostram que a infecção pelo VSR do grupo A protege parcialmente contra a infecção pelos dois grupos do vírus, porém a infecção pelo grupo B induz a baixos títulos de anticorpos contra o grupo A (Ogra, 2004). A glicoproteína F é a mesma nos dois grupos de VSR, enquanto a glicoproteína G diverge entre os grupos. O grupo do VSR predominante pode variar a cada ano e de uma região para outra. Ainda não está esclarecido qual o grupo relacionado à doença pulmonar mais grave. Há relatos que as cepas do grupo A podem estar associadas a uma evolução clínica mais grave (Hall, 1998; Tirado et al.,1995). O grupo A apresenta cinco genótipos distintos com 22 subtipos e o grupo B quatro genótipos com seis subtipos (Peret et al., 1998).

O VSR é relativamente lábil, mantendo 10\% de sua infectividade após

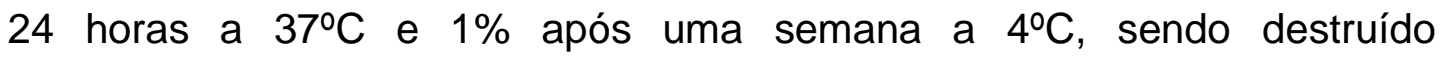
rapidamente a $55^{\circ} \mathrm{C}$. Tolera pouco mudanças de temperatura e $\mathrm{pH}$ (Filippell e Rearick, 1993; Hall, 1998). A replicação viral ocorre somente no citoplasma, sem necessitar das funções nucleares da célula hospedeira 
(Arvin e Maldonado, 2001). A estrutura viral pode ser vista na Figura 1 (The University of Warwick, 2000).

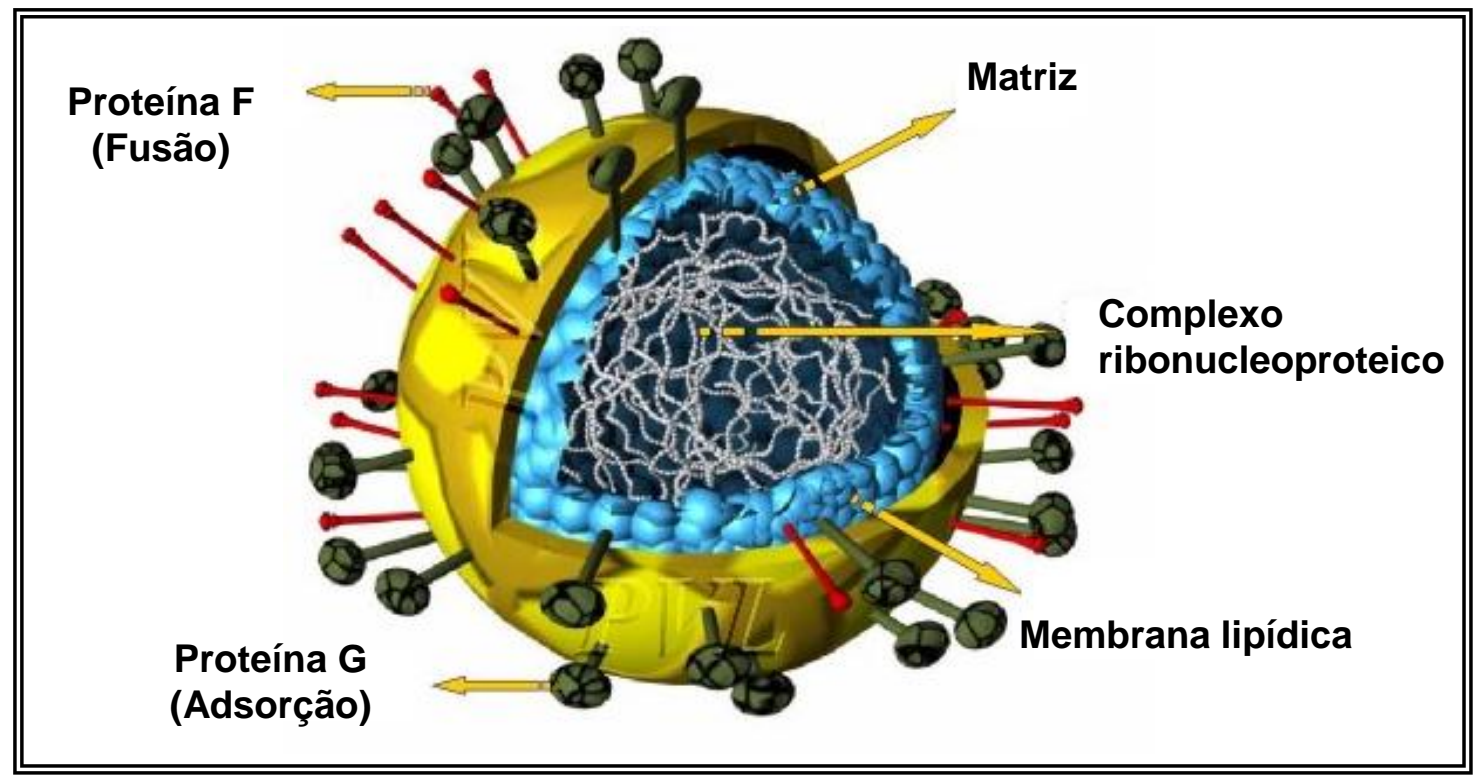

FIGURA 1. Esquema representativo do vírus sincicial respiratório (Modificado de The University of Warwick, 2000)

\subsection{Infecção pelo VSR}

O VSR infecta o epitélio respiratório pela interação entre os domínios de ligação-heparina da glicoproteína $G$ e os glicosaminoglicanos da superfície da célula (Martinez e Melero, 2000). Tanto a glicoproteína G como a F são capazes de se ligar aos glicosaminoglicanos da célula hospedeira, porém a glicoproteína $G$ contribui com a maioria das ligações virais (Bourgeois et al., 1998). Entretanto, nem a glicoproteína G nem a SH são necessárias para a infectividade do VSR, conforme pode ser demonstrado em isolamentos de VSR mutante com ausência dos genes $\mathrm{G}$ e SH (Techaarpornkul et al., 2002). A região central conservada de cistina, não glicosilada, da glicoproteína G parece ter papel na infecção pelo VSR. Esta 
região contém a quimiocina CX3C (fractalcina), que é capaz de interagir com o seu receptor específico, CX3CR1, e facilitar a infecção pelo VSR através da alteração do tráfego de células $\mathrm{CX} 3 \mathrm{CR} 1^{+}$(linfócitos $\mathrm{T}$, células $\mathrm{NK}$, monócitos e macrófagos) aos tecidos com infecção viral (Tripp et al., 2001). A glicoproteína $G$ pode ser expressa nas seguintes formas: ligada à membrana do VSR e secretada pelas células do epitélio respiratório infectadas pelo vírus. Aproximadamente $15 \%$ da glicoproteína G sintetizada nas células infectadas é secretada na forma solúvel, que possui as mesmas características da forma ligada à membrana viral (Hendricks et al., 1988).

A glicoproteína G pode também interagir com a L-selectina (receptor do VSR nos leucócitos) e com a anexina II (receptor do VSR nas células epiteliais humanas). A anexina II solúvel e o antagonista da L-selectina, TBC 1269, podem inibir a infecção das células epiteliais pelo VSR. Estes achados sugerem que a infecção das células mononucleares do sangue periférico pelo VSR pode contribuir para a persistência viral no organismo (Malhotra et al., 2003; Yui et al., 2003). Estudos experimentais em camundongos evidenciam latência (ácido ribonucleico (RNA) genômico) e persistência (ácido ribonucleico mensageiro (RNAm)) do VSR, apesar da presença de linfócitos citotóxicos e imunoglobulina G específicos para o vírus (Schwarze et al., 2004).

\subsection{Resposta do hospedeiro à infecção pelo VSR}

Os mecanismos de defesa do hospedeiro contra infecção pelo VSR envolvem aspectos da imunidade inata e adaptativa, onde a magnitude e a 
qualidade da resposta imune adaptativa é dependente da resposta inata (Figura 2). A interação do VSR com o epitélio respiratório induz uma via de sinalização intracelular, resultando na ativação do mecanismo antiviral que inclui a elaboração de citocinas, quimiocinas e elementos intrínsecos (caspases e proteínas Bcl-2) que regulam a sobrevivência celular. O padrão de expressão de citocinas e quimiocinas ativa a migração de células imunes para os locais com infecção, regula a subsistência das células $B$ e $T$, e pode intensificar a eliminação viral ou exacerbar a doença respiratória. Estudos em humanos e em modelos animais sugerem que a resposta imune à infecção pelo VSR é influenciada pela expressão protéica viral, qualidade da estimulação antigênica (vírus nativo ou tratado com formalina), localização do estímulo (respiratório ou subcelular), pelo padrão de expressão de citocinas e quimiocinas (tipo Th1 ou Th2), e por fatores não imunes do hospedeiro, como a substância P (neuropeptídeo com efeito broncoconstritor significante) (Tripp, 2004).

As células infectadas pelo VSR expressam quimiocinas, que recrutam células imunes para os locais com infecção. Células imunes inatas, com as células NK, respondem rapidamente aos sinais das quimiocinas e secretam citocinas antivirais para controlar a infecção e ativar células da resposta imune adaptativa. As células $T$ recrutadas para os locais com infecção tornam-se ativas, proliferam e diferenciam-se em células efetoras e de memória, que contribuem para o desenvolvimento das respostas humoral e citotóxica das próprias células $T$. As células $T$ citotóxicas reconhecem células infectadas por vírus e levam à sua morte para poder controlar a 
infecção. As células $T$ efetoras têm vida relativamente curta, enquanto as células $\mathrm{T}$ de memória persistem por mais tempo. A resposta humoral, mediada pelas células $B$, é importante para resistir a reinfecções e tem duração prolongada (Tripp, 2004).

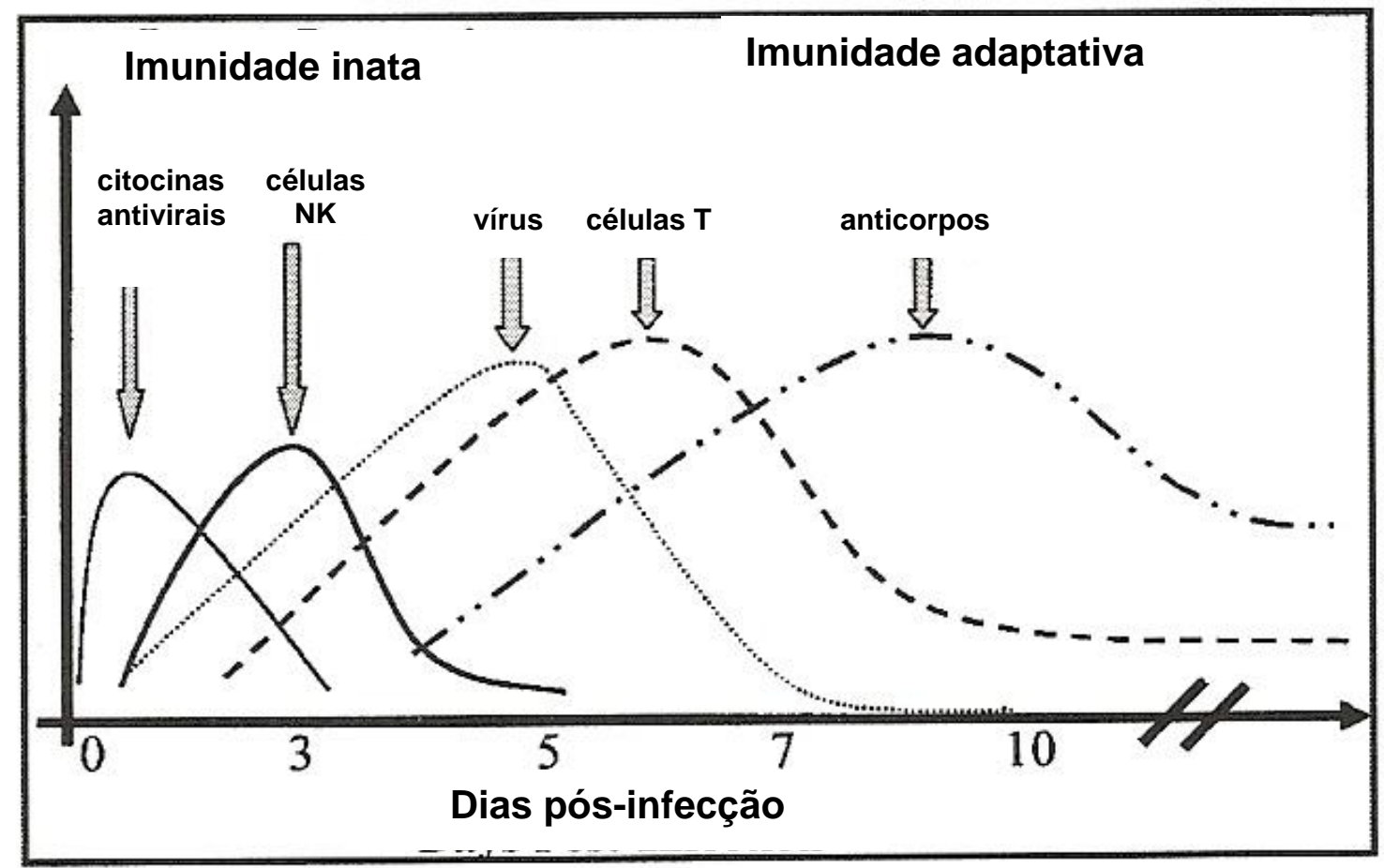

FIGURA 2. Mecanismos de defesa do hospedeiro contra a infecção pelo VSR (Modificado de Tripp, 2004)

\subsubsection{Imunidade inata}

A imunidade inata é responsável pela primeira linha de resistência à infecção pelo VSR. Uma variedade de componentes secretados no trato respiratório contribuem para inibir a infecção pelo VSR, tais como colectinas, lactoferrina e proteínas secretadas pelas células Clara (Sano et al., 2003; Wang et al., 2003). Muitos destes componentes da imunidade inata ligam-se às glicoproteínas de superfície do VSR e facilitam a eliminação viral através da agregação ou da ativação da função leucocitária. Outros achados 
importantes na resposta inata à infecção pelo VSR são os receptores de reconhecimento padrão (PRRs), que exibem ampla especificidade para patógenos associados a padrões moleculares (PAMPs) não encontrados nos hospedeiros (Underhill e Ozinsky, 2002). Há dois grandes grupos de PRRs: os secretados, que incluem o CD14 e as proteínas da família colectina, e os associados a células, como as moléculas adaptadoras e os toll-like receptors (TLRs) (Akira et al., 2001; LeVine et al., 1999). As proteínas da família colectina incluem as proteínas A (SP-A) e D (SP-D) do surfactante, que funcionam como PRRs para as porções com carboidrato dos vírus e interagem com as células fagocitárias para induzir à opsonização das partículas virais. A SP-A parece ser o PRR mais importante na imunidade inata à infecção pelo VSR. A SP-A liga-se à subunidade $F_{2}$ da glicoproteína $F$, que é altamente glicosilada, mas não à glicoproteína $G$, e neutraliza a infecção pelo VSR (Shepherd, 2002). Os TLRs, especializados em reconhecer PAMPs específicos, são receptores do sistema imune inato expressos principalmente em monócitos e macrófagos, mas também em células dendríticas e células B. O TLR2 geralmente reconhece o peptidoglicano de bactérias Gram-positivo, enquanto o TLR4 reconhece o lipopolissacarídeo da membrana externa de bactérias Gram-negativo, além de ser importante para a resposta imune inata à infecção pelo VSR. A glicoproteína F do VSR estimula a imunidade inata através do CD14 e TLR4 (Kurt-Jones et al., 2000). Em estudos com camundongos deficientes em TLR4 há falha na migração pulmonar de células NK e CD14, redução na função das células NK, falha na expressão de IL-12 e na eliminação do VSR 
(Haynes et al., 2001). A infecção das células epiteliais respiratórias pelo VSR levam ao aumento da expressão do RNAm do TLR4 e do TLR4 localizado na membrana celular (Monick et al., 2003). A expressão de quimiocinas e citocinas associada à infecção pelo VSR parece ser inicialmente TLR4dependente e independente da replicação viral (Haeberle et al., 2002). Crianças com bronquiolite pelo VSR apresentam aumento da expressão de TLR4 nos monócitos do sangue periférico (Gagro et al., 2004).

A infecção das células epiteliais respiratórias pelo VSR induz à expressão de um espectro de quimiocinas e citocinas que afeta o balanço entre a eliminação viral e a patogênese da doença (Figura 3).

As células do epitélio alveolar humano infectadas pelo VSR levam à expressão de três superfamílias de quimiocinas: a) um grupo contendo fractalcina, MIP-1 $\alpha$ e MIP-1 $\beta$, b) outro grupo contendo MCP-1, RANTES e IL8, e c) um grupo contendo growth-related oncogene-alpha (Gro- $\alpha$ ) e Exodus1 (Zhang et al., 2001). Nos aspirados nasofaríngeos e traqueais de crianças com bronquiolite e/ou pneumonia pelo VSR tem sido detectado a presença de citocinas tipos Th1 (IL-2, IL-12 e IFN-r) e Th2 (IL-4, IL-5, IL-6 e IL-13), RNAm de CC quimiocinas (MIP-1 $\alpha$, MIP-1 $1 \beta$ e RANTES), outras quimiocinas (IL-8) e citocinas (TNF- $\alpha$ e IL-1 $\beta$ ), além de moléculas de adesão, como a sICAM-1, a VCAM-1 e a E-selectina (Ogra, 2004; Sheeran et al., 1999; Tripp et al., 2002). Muitos estudos mostram que o padrão de expressão das citocinas e quimiocinas pode ser correlacionado com a gravidade da doença respiratória (Hornsleth et al., 2001; Noah et al., 2002; Sheeran et al., 1999; Smyth et al., 2002; Tripp et al., 2002). A RANTES e a MIP-1a são as 
quimiocinas expressas durante a infecção pelo VSR que têm sido correlacionadas com bronquiolite grave (Garofalo et al., 2001; Harrison et al., 1999). Quadro respiratório grave também tem sido observado quando há variações genéticas no receptor (CCR5) da RANTES e da MIP-1a (Hull et al., 2003).

Entre as células da imunidade inata que respondem às citocinas e quimiocinas elaboradas estão os macrófagos, eosinófilos, basófilos, neutrófilos e as células NK. Estas células têm um papel importante no controle da infecção, porém uma resposta exacerbada destas células pode aumentar a inflamação e contribuir para a patogênese da doença. Eosinófilos contendo moléculas catiônicas, ribonucleases, eosinófilo derivado de neurotoxina (EDN) e proteína catiônica eosinofílica (ECP) exibem atividade antiviral, no entanto uma expressão inadequada destes mediadores está ligada à hiper-reatividade brônquica e exacerbação da infecção pelo VSR (Ehlenfield et al., 2000). Do mesmo modo, neutrófilos contendo mieloperoxidase, defensinas e catepsina G bloqueiam a ação viral, porém um desbalanço na expressão destes mediadores está associado a respostas inflamatórias exacerbadas e dano às células epiteliais respiratórias das crianças com bronquiolite grave pelo VSR (Abu-Harb et al., 1999). 


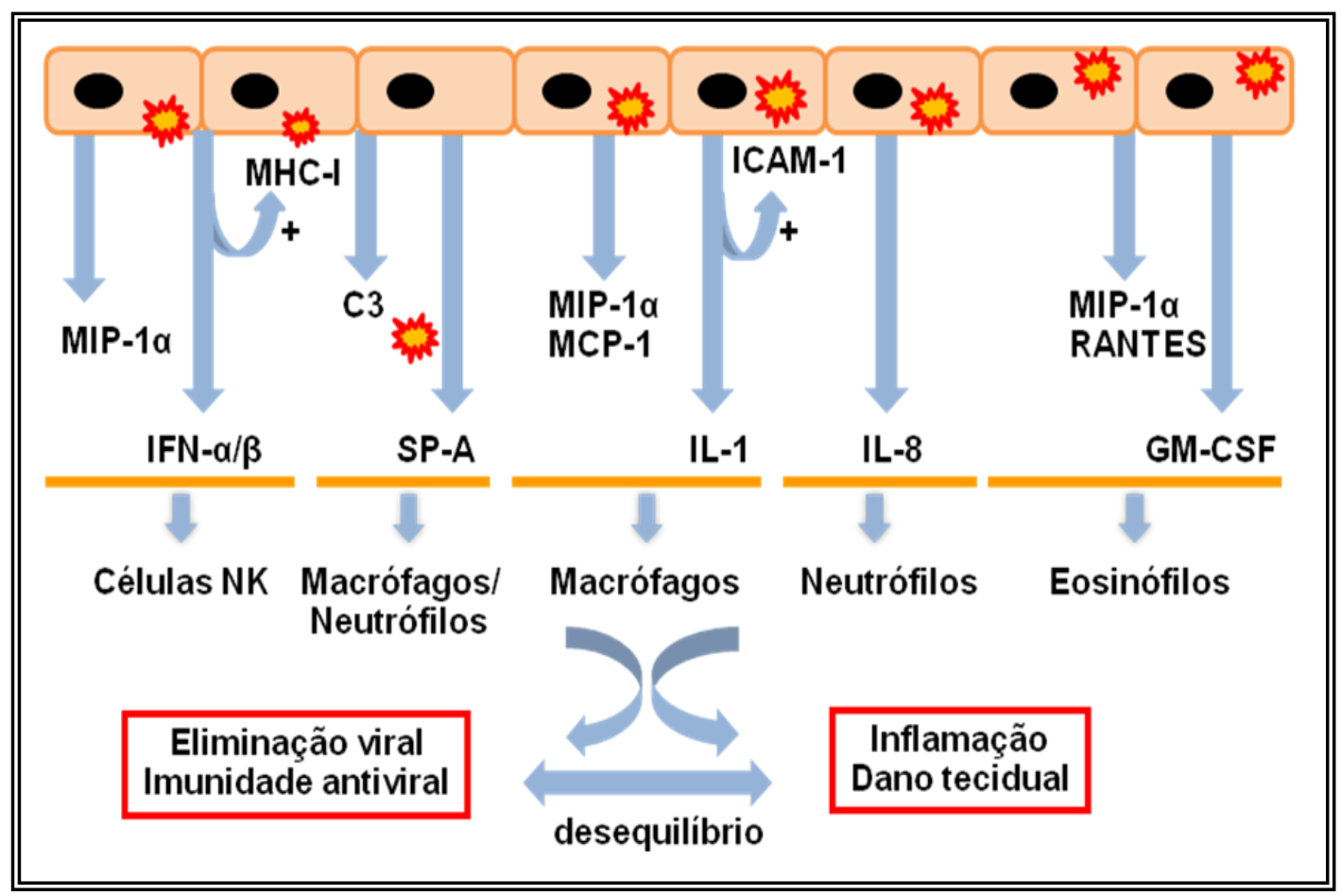

FIGURA 3. Infecção do epitélio respiratório pelo VSR ( Modificado de Garofalo e Haeberle, 2000); GM-CSF= granulocyte macrophage-colony stimulating factor; $\mathrm{MHC}-\mathrm{I}=$ complexo de histocompatibilidade maior classe I; IFN- $\alpha / \beta=$ interferons-alfa/beta; $C 3=$ componente $\mathrm{C} 3$ do complemento

\subsubsection{Imunidade adaptativa}

A imunidade adaptativa é composta pelas respostas das células B (humoral) e T (mediada por células) e dotada de especificidade antigênica, memória e auto-tolerância. A resistência à infecção pelo VSR nas vias aéreas superiores é mediada pela expressão local e transitória de $\lg A$ secretora, entretanto uma resistência humoral mais duradoura é associada à $\lg \mathrm{M}$ e, especialmente, aos anticorpos neutralizantes $\lg \mathrm{G}$ (Crowe et al., 2001). Os títulos de anticorpos ( $\lg A, \lg M$ e $\lg G$ ) secretados pelas mucosas e séricos são menores nas crianças com idade inferior a 6 meses e apresentam redução alguns meses após a infecção, fatores estes que podem auxiliar na reinfecção alta pelo VSR nesta faixa etária (Hall et al., 1999; Murphy et al., 1986). 
A infecção primária pelo VSR induz a produção de $\operatorname{lgM}$ em 5 a 10 dias, dependendo da idade do paciente. Geralmente, os anticorpos IgM persistem por 1 a 3 meses, porém alguns estudos demonstram que os anticorpos IgM contra o VSR podem permanecer detectáveis por pelo menos 1 ano (Ruuskanen e Ogra, 1993). Os anticorpos IgG específicos para o VSR atingem valores máximos em 20 a 30 dias após o início dos sintomas respiratórios. A resposta IgG ocorre principalmente nas subclasses IgG1 e IgG3, indicando a natureza antigênica das proteínas F e G do VSR. Após 1 ano da infecção primária, os níveis de lgG específica para o VSR declinam até valores mínimos. Após a reinfecção pelo VSR, um efeito booster é notado com títulos altos de lgG detectáveis dentro de 5 a 7 dias. A produção de IgA sérica ocorre alguns dias após a produção de $\lg M$ e $\lg G$. A IgA antiVSR livre surge em 2 a 5 dias após a infecção, com pico dos títulos entre 8 e 13 dias. As secreções nasais contém IgE específica livre e ligada à célula durante a infecção pelo VSR (Welliver et al., 1980).

Estudos clínicos e laboratoriais têm mostrado que os anticorpos de mucosa e séricos contribuem para a proteção contra a infecção ou reinfecção pelo VSR, e nas crianças o nível de anticorpos maternos adquiridos passivamente correlaciona-se à proteção contra a ITRI pelo VSR. A administração passiva de anticorpos monoclonais humanizados específicos para o VSR pode prevenir a doença respiratória grave em crianças com fatores de risco, mas anticorpos anti-VSR podem também contribuir para a patogênese da doença (Vogel et al., 2002). Os anticorpos quando reagem com o VSR podem causar uma intensificação da infecção 
viral em certos tipos de células que expressam receptores Fc, como macrófagos e células B, e levar a um mecanismo de latência ou persistência do vírus no organismo (Guerrero-Plata et al., 2004; Schwarze et al., 2004; Valarcher et al., 2001). Os anticorpos podem exacerbar a patogênese da doença associada à infecção natural pelo VSR ou à vacinação (ocorrida na década de 1960, pelo VSR inativado pela formalina). Estudos em camundongos mostram que a formação de complexos imunes está associada à presença de grandes quantidades de anticorpos não neutralizantes no momento da replicação pulmonar do VSR, e a exacerbação da doença pelo vírus é abolida em camundongos com deficiência de células B e componente C3 do complemento (Polack et al., 2002).

Os antígenos que entram nas células através de compartimentos endocíticos, como o VSR inativado pela formalina, são apresentados às células $\mathrm{T} \mathrm{CD}^{+}$via complexo de histocompatibilidade maior (MHC) classe II, que é expresso nas células dendríticas e monócitos durante a infecção aguda pelo VSR. Enquanto os antígenos produzidos intracelularmente e que passam pelo complexo de Golgi, como os produzidos durante a infecção natural pelo VSR, são apresentados às células $\mathrm{T} C D 8^{+}$via $\mathrm{MHC}$ classe I. A infecção pelo VSR é controlada inicialmente pelas células $T$, que são importantes na proteção contra o quadro respiratório grave e na limitação da excreção viral (Chandwani et al., 1990). Células mononucleares do sangue periférico de crianças com infecção aguda pelo VSR contém células T citotóxicas específicas para o vírus. Estudos em camundongos mostram que 
tanto as células $\mathrm{T} \mathrm{CD}^{+}{ }^{+}$e $\mathrm{CD} 8^{+}$estão envolvidas no término da replicação viral, contribuindo para imunidade e afetando aspectos da patogênese da doença pelo VSR (Graham et al., 2002; Openshaw et al., 2001; Peebles et al., 2003). Células $\mathrm{T} \mathrm{CD}^{+}$parecem ter papel determinante no controle da doença pelo VSR e as proteínas do vírus M2, F e N são os maiores alvos dos linfócitos T citotóxicos (Openshaw, 1995). Em modelos experimentais com animais, a resistência do hospedeiro à infecção pode ser mediada pela sensibilização à proteína M2 do VSR, e a depleção de células T CD8 ${ }^{+}$abole a proteção associada à proteína $\mathrm{M} 2$, enquanto a depleção de células T CD4 ${ }^{+}$ tem um efeito intermediário (Connors et al., 1992). A infecção pelo VSR parece suprimir a atividade efetora das células $\mathrm{T} \mathrm{CD}^{+} \mathrm{M} 2$-específicas e o desenvolvimento das células $\mathrm{T} \mathrm{CD} 8^{+}$pulmonares de memória; entretanto, o desenvolvimento das células $\mathrm{T} \mathrm{CD8}{ }^{+}$pulmonares efetoras M2-específicas e das células $\mathrm{T} \mathrm{CD}^{+}$de memória pode ser aumentado pela expressão in situ de IL-2 (Chang et al., 2004). As células T CD4 ${ }^{+}$expressam um espectro de citocinas necessário para as respostas imunes mediadas por células, incluindo IL-2 e IFN-r, que podem contribuir para resposta antiviral. Em camundongos, a infecção primária pelo VSR induz uma resposta mista de citocinas tipos Th1/Th2 que limita a patogênese da doença, e a expressão precoce de IFN-r parece ser importante no controle do balanço das citocinas Th1/Th2 (Boelen et al., 2002). A ausência da expressão precoce de IFN-Y após infecção primária ou durante as infecções subsequentes pelo VSR pode resultar em resposta predominante das citocinas tipo Th2 e aumentar a gravidade da doença respiratória (Durbin et al., 2002). 


\subsection{Imunidade e patogênese da doença pelo VSR}

A resposta imune à infecção pelo VSR é baseada principalmente na resposta adaptativa que resiste à reinfecção pela mesma cepa do vírus e promove um nível de proteção contra epitopos antigênicos conservados entre as cepas. Em contraste, o VSR causa infecções do trato respiratório inferior graves em fases precoces e tardias da vida, e infecções de repetição pelas mesmas cepas ou cepas diferentes são comuns (Peret et al., 2000). Há evidências fortes de que a infecção pelo VSR pode resultar em latência e persistência viral no hospedeiro (Valdovinos e Gomez, 2003). As células dendríticas podem funcionar como reservatórios para o VSR fora da sazonalidade do mesmo e a replicação viral pode ser induzida neste tipo de célula através da produção endógena de óxido nítrico (Stevens et al., 2008). Estes fatos sugerem que o VSR pode modular aspectos da resposta imune para promover a sua replicação. A falha da vacinação com VSR inativado pela formalina, com exacerbação da doença nas crianças imunizadas frente à infecção natural pelo vírus, pode ser atribuída ao desenvolvimento de complexos imunes, à resposta imune desbalanceada e à pouca proteção oferecida (Polack et al., 2002). Estudos com camundongos mostram que as proteínas do VSR sob a ação da formalina, principalmente a forma secretada da glicoproteína G, podem sensibilizar para doença pulmonar mais grave com eosinofilia pulmonar, que parece ser dependente das IL-4 e IL-13, da produção de citocinas tipo Th2, da resposta alterada das quimiocinas, do aumento da expressão pulmonar de substância $P$, do recrutamento de neutrófilos para o pulmão, e da hemorragia pulmonar (Varga e Braciale, 
2002). Deste modo, a glicoproteína $G$ associada à expressão de citocinas e/ou quimiocinas pode modificar a resposta inflamatória das células $\mathrm{T}$ durante a infecção pelo VSR. Em humanos, as IL-4 e IL-13 também favorecem o desenvolvimento de doença pulmonar mais grave pelo VSR e a inibição de suas atividades pode reduzir a intensidade do quadro respiratório viral (Tang e Graham, 1994).

É necessário o conhecimento dos mecanismos do hospedeiro e do vírus que regulam a expressão de citocinas e quimiocinas para que se desenvolvam uma vacina específica e intervenções estratégicas para o VSR. O VSR durante a replicação nas células do epitélio respiratório ativa grupos de genes do hospedeiro que promovem os fatores de transcrição, também denominados de sinais transdutores e ativadores de transcrição (STATs), como os fatores nucleares IL-6 (NF-IL-6) e kappaB (NF-kB), e os supressores de sinalização das citocinas (SOCS). A síntese e a resposta funcional das citocinas (TNF- $\alpha$, IL-1 $\beta$, IL-2 e IL-6), quimiocinas (IL-8, MIP-1 $\alpha$ e MCP-1), moléculas de adesão celular (sICAM-1, VCAM-1 e E-selectina) e outras proteínas imunomodulatórias, como os fatores de crescimento GMCSF e G-CSF, são reguladas pelos fatores de transcrição e pelas proteínas SOCS, que podem afetar a patogênese da doença. As proteínas SOCS têm papel crítico na função das células $T$, achado este que pode ser utilizado pelo VSR para alterar as respostas antivirais. Os vírus podem modificar a expressão das proteínas SOCS para manipular a via de citocinas Th1/Th2 e a resposta antiviral do hospedeiro. O NF-KB inclui membros importantes da família do fator regulador de interferon (IRF), sendo o IRF-1 necessário para 
o desenvolvimento das respostas imunes tipo Th1 e a sua ausência induz às respostas imunes tipo Th2 (Liu et al., 2004; Tripp et al., 2005).

\subsubsection{Quimiocinas na infecção pelo VSR}

Crianças hospitalizadas por infecção pelo VSR têm aumento da expressão de RNAm de MIP-1a (CCL3; atração de eosinófilos), MIP-1ß (CCL4; ativação e quimiotaxia para granulócitos), MCP-1 (CCL2; quimiotaxia para monócitos) e RANTES (CCL5; quimiotaxia para células T, eosinófilos e basófilos) nas células mononucleares do sangue periférico, indicando que a gravidade da infeção pelo VSR possa estar associada ao padrão ou magnitude da expressão das quimiocinas. A expressão da glicoproteína $G$ e/ou SH do VSR pelas células broncoalveolares infectadas tem sido associada a alterações na expressão de RNAm das quimiocinas (IP-10: CXCL10 envolvida em reações de hipersensibilidade de início tardio, MIP-

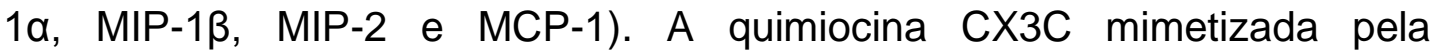
glicoproteína G do VSR afeta as funções da fractalcina. A fractalcina (CX3CL1) é a única quimiocina que tem função quimiotáctica e de molécula de adesão celular (Tripp et al., 2002; Welliver, 2003). A forma ligada à membrana da glicoproteína G promove a adesão celular aos receptores CX3CR1 expressos nos linfócitos T, células NK, monócitos e macrófagos, e

a forma solúvel age como quimiotáctica para as células $\mathrm{CX} 3 \mathrm{CR} 1^{+}$. É possível que a expressão da glicoproteína $\mathrm{G}$ iniba as respostas mediadas pela fractalcina, que afetam os achados da imunidade e a patogênese da doença. Células NK, células tipo Th1 e linfócitos T citotóxicos expressam altos níveis de CX3CR1, respondem à fractalcina e são componentes 
importantes da imunidade antiviral (Piedimonte et al., 2004). Em contraste, as células tipo Th2 tem propriedades antivirais menores, expressam níveis baixos de receptor CX3CR1 e respondem à fractalcina (Fraticelli et al., 2001). O mimetismo da quimiocina $C X 3 C$ pela glicoproteína $G$ pode alterar a ativação e/ou tráfego de células $\mathrm{CX} 3 \mathrm{CR} 1^{+}$para os locais com infecção e levar a uma resposta antiviral tipo Th2 menos potente.

\subsubsection{Interações neuroimunes associadas à infecção pelo VSR}

A infecção pelo VSR é associada à inflamação neurogênica intensa das vias aéreas, já que as fibras nervosas sensitivas do pulmão são localizadas abaixo da superfície do epitélio e podem captar mudanças na região brônquica. Estas células neuronais liberam neuropeptídeos próinflamatórios (substância $P$, neurocinina $A$ e neurocinina $B$ ) durante a infecção pelo VSR. A substância $P$ e as neurocininas $A$ e $B$ pertencem à família dos hormônios peptídeos denominados taquicininas (Piedimonte, 2003). A resposta da substância $P$ à infecção pelo VSR parece estar associada à expressão das glicoproteínas $\mathrm{G}$ e/ou $\mathrm{SH}$, um efeito que pode ser mediado pela interação glicoproteína G CX3C-CX3CR1 (Tripp et al., 2003). A infecção pelo VSR também induz à expressão de receptores de afinidade alta para a substância $P$, que é o receptor neurocinina 1 (NK-1R) nas células epiteliais pulmonares e imunes, principalmente nas células $T$ CD4 $^{+}$(Piedimonte, 2003). A expressão da substância P pode estimular a produção de uma variedade de mediadores inflamatórios, incluindo IL-1, IL6, IL-10, IL-12 e TNF- $\alpha$; e a expressão de IL-12 e IL-18 pode ativar as células T que regulam a expressão do receptor NK-1R. Interações entre a 
substância $\mathrm{P}$ e o receptor NK-1R nas células $\mathrm{T}$ promove a síntese de IFN-ץ, sugerindo que a substância $P$ exerce um papel na via antiviral (Weinstock et al., 2003). Embora a substância $P$ possa contribuir para a imunidade antiviral, sua expressão pode exercer efeito inibitório direto na ativação leucocitária e efeito indireto no recrutamento celular para os locais com infecção pela modificação na proliferação de células inflamatórias, na produção de citocinas e na expressão de vários receptores de superfície celular (Luger, 2002). Camundongos infectados pelo VSR apresentam altos níveis de expressão pulmonar de substância $P$, que se associam a respostas alteradas das células NK durante as infecções primária e secundária pelo vírus. Nos camundongos submetidos à vacinação com VSR inativado pela formalina, a expressão da substância $P$ intensifica a eosinofilia pulmonar, bem como o aumento do tráfego pulmonar de células polimorfonucleares (Tripp et al., 2000). De acordo com estes resultados, a substância P pode contribuir para a patogênese da doença pelo VSR.

Neurônios e células imunes que expressam substância P podem também expressar o receptor CX3CR1 e são responsivos à fractalcina. $A$ interação glicoproteína G CX3C-CX3CR1 pode durante a infecção pelo VSR mimetizar a atividade da fractalcina e induzir a expressão de substância $P$ (Combadiere et al., 2003). Esta hipótese é confirmada pela administração de anticorpos monoclonais anti-CX3CR1, anti-substância P e anti-glicoproteína G a camundongos infectados pelo VSR com redução dos níveis pulmonares de substância $P$ e da patogênese da doença, além da normalização do padrão respiratório dos animais, sugerindo que um possível mecanismo para 
a apneia associada à infecção pelo VSR seja a ligação da glicoproteína G ao receptor CX3CR1 e a indução de substância $P$ (Haynes et al., 2003).

\subsection{Perspectivas para prevenção e tratamento da infecção pelo VSR}

O VSR causa infecções do trato respiratório superior e inferior em todas as idades, e uma vacina específica para ser eficaz necessita conferir proteção melhor do que aquela associada à infecção natural pelo vírus. Para que uma vacina seja bem sucedida em lactentes jovens, esta deve induzir proteção completa e duradoura em um sistema imune imaturo na presença de anticorpos maternos. Atualmente, há vários estudos experimentais sendo desenvolvidos com vacinas de subunidades, de vírus vivo atenuado, de ácido desoxiribonucleico (DNA) e de vetor vivo. Talvez, o desenvolvimento de uma vacina modificada geneticamente com vírus vivo atenuado tenha maior vantagem, já que o genoma do VSR pode ser manipulado para oferecer máxima imunogenicidade e atenuação. As vacinas com vírus vivo atenuado também têm a vantagem de mimetizar a infecção natural pelo VSR (Tripp et al., 2004).

Achados da patogênese do VSR adquiridos em estudos com modelos animais devem ser considerados no desenho de uma vacina específica segura e eficaz, e utilizados para modificar ou silenciar regiões do genoma do VSR, que podem estar associadas a alterações da imunidade ou à patogênese da doença. Entre os alvos das pesquisas para profilaxia e tratamento da infecção pelo VSR estão a glicoproteína G CX3C, que através 
da indução de substância P pode intensificar a resposta inflamatória nas vias aéreas e levar a crises de apneia, e os mediadores inflamatórios e seus receptores, que podem afetar a gravidade da doença viral (Haynes et al., 2003; Tripp et al., 2003). Os estudos para prevenção e tratamento da infecção pelo VSR visam a inibição da replicação viral, a redução da inflamação no trato respiratório e a eliminação do vírus (Haynes et al., 2002; Stevens et al., 2008).

Apesar das pesquisas com animais fornecerem diversas informações sobre os mecanismos de imunidade e da patogênese da doença associada à infecção pelo VSR, muitas dúvidas permanecem. Entre as questões ainda não solucionadas pode-se citar: o porquê da infecção pelo VSR não levar a uma imunidade duradoura, quais são os componentes do VSR que induzem resistência à infecção ou imunidade, e quais são os mecanismos associados à latência ou persistência do VSR no organismo. 
3

OBJETIVOS 


\section{OBJETIVOS}

\subsection{Geral}

- Avaliar se as concentrações dos mediadores inflamatórios (RANTES, sICAM-1, TNF- $\alpha$, IL-6 e IL-10) e as suas razões na secreção nasofaríngea e no sangue de crianças com idade inferior a 3 meses e ITRI pelo VSR correlacionam-se à gravidade da doença.

\subsection{Específicos}

- Determinar a frequência dos grupos A e B do VSR nas crianças infectadas com idade inferior a 3 meses internadas na UCINE do Instituto da Criança do HCFMUSP.

- Avaliar se há diferença na gravidade da doença respiratória pelo VSR entre as crianças com idade inferior a 3 meses internadas na UCINE e infectadas pelas cepas dos grupos A e B do vírus.

- Comparar as concentrações dos mediadores inflamatórios (RANTES, sICAM-1, TNF- $\alpha, \quad$ IL-6 e IL-10) na secreção nasofaríngea e no sangue de crianças com idade inferior a 3 meses e ITRI pelo VSR à admissão hospitalar ou adquirida durante a internação na UCINE, no terceiro e sétimo dias de evolução ou por ocasião da alta hospitalar (se antes do sétimo dia). 
- Comparar as concentrações respiratórias e séricas dos mediadores inflamatórios (RANTES, sICAM-1, TNF- $\alpha$, IL-6 e IL-10) à admissão hospitalar, de acordo com a ITRI pelos grupos $A$ e $B$ do VSR.

- Descrever a evolução das concentrações dos mediadores inflamatórios (RANTES, sICAM-1, TNF- $\alpha, \quad$ IL-6 e IL-10) na secreção nasofaríngea e no sangue de crianças com idade inferior a 3 meses e ITRI pelo VSR à admissão hospitalar ou adquirida durante a internação na UCINE, no terceiro e sétimo dias de evolução ou por ocasião da alta hospitalar (se antes do sétimo dia). 
4

MÉTODOS 


\section{MÉTODOS}

\subsection{Local do estudo}

A UCINE do Instituto da Criança do HCFMUSP é uma unidade de terapia intensiva neonatal que dispõe de 20 leitos distribuídos entre casos clínicos e cirúrgicos, de acordo com a necessidade do Serviço. Apresenta duas salas privativas para casos que necessitem de isolamento. Os pacientes internados são procedentes do Berçário Anexo à Maternidade do HCFMUSP e de outros Hospitais ou Maternidades de São Paulo, de outros municípios e estados do Brasil.

\subsection{Critérios de inclusão e exclusão}

No período compreendido de julho de 2004 a dezembro de 2005 foram incluídas no estudo prospectivo, de coorte, observacional, 30 crianças com idade inferior a 3 meses portadoras de ITRI pelo VSR internadas na UCINE, que apresentavam bronquiolite e/ou pneumonia e necessidade ou não de ventilação mecânica devido à insuficiência respiratória ou apneia. Quando a mesma criança foi internada mais de uma vez ou houve recorrência da infecção pulmonar durante a internação, esta foi considerada como um caso novo.

Não houve recusa por parte dos pais ou responsáveis para que as crianças participassem da pesquisa. Foram excluídos do estudo 39 pacientes que apresentavam resultado negativo ou inconclusivo para 
pesquisa de VSR nas vias aéreas (nove casos), cardiopatia cianogênica, displasia broncopulmonar, doença do refluxo gastroesofágico, sepse bacteriana e/ou fúngica à admissão hospitalar, infecções congênitas do grupo TORCHS, hemorragia intracraniana, malformações do sistema nervoso central e da caixa torácica, submissão a procedimentos cirúrgicos, uso de broncodilatadores e/ou corticosteroides, e história familiar de atopia. Tanto as patologias citadas acima como a realização de cirurgias e a utilização de medicamentos broncodilatadores/anti-inflamatórios podem alterar o padrão respiratório dos pacientes e/ou os níveis dos mediadores inflamatórios no organismo.

Os critérios para definição de ITRI foram clínicos e radiológicos. Os critérios clínicos estabelecidos foram presença de taquipneia, cianose, retrações torácicas e roncos, sibilos ou crepitações, difusos ou localizados, ao exame físico do tórax realizado pela autora. Os critérios radiológicos foram hiperinsuflação pulmonar difusa e/ou velamento intersticial/alveolar.

O diagnóstico de infecção pelo VSR foi realizado através da reação de imunofluorescência indireta (IFI) em aspirado de secreção nasofaríngea ou do isolamento viral em cultura celular.

Utilizamos para avaliar a gravidade da doença respiratória os seguintes marcadores clínicos: sistema de escore clínico modificado de De Boeck et al. (1997) (Tabela 1), tempos de oxigenoterapia e de ventilação mecânica e duração da internação. As avaliações da saturação de oxigênio da hemoglobina foram realizadas com oxímetro Ohmeda, modelo 3700 (EUA), disponível na UCINE. 
TABELA 1 - SISTEMA DE ESCORE CLÍNICO MODIFICADO

\begin{tabular}{|c|c|c|c|c|}
\hline ESCORE & $\begin{array}{c}\text { FREQUÊNCIA } \\
\text { RESPIRATÓRIA }\end{array}$ & SIBILÂNCIA & $\begin{array}{c}\text { SATURAÇÃO } \\
\mathrm{O}_{2}(\%)\end{array}$ & $\begin{array}{c}\text { USO DE } \\
\text { MUSCULATURA } \\
\text { ACESSÓRIA }\end{array}$ \\
\hline 0 & $<30$ & Nenhuma & $\geq 95$ & Nenhum \\
\hline 1 & 31 a 45 & $\begin{array}{l}\text { Término da } \\
\text { expiração* }\end{array}$ & 90 a 94 & Mínimo \\
\hline 2 & 46 a 60 & $\begin{array}{l}\text { Expiração total e } \\
\text { inspiração* }\end{array}$ & $<90$ & Moderado \\
\hline 3 & $>60$ & $\begin{array}{l}\text { Expiração e } \\
\text { inspiração** }\end{array}$ & $<85$ & Máximo \\
\hline
\end{tabular}

"Com estetoscópio; ** sem estetoscópio; valores de escore e classificação da gravidade: $\leq 3$ : normal, 4-6: leve, 7-9: moderada e 10-12: grave. Modificado de De Boeck et al. (1997).

Para todos os pacientes foram preenchidos protocolos específicos para doenças pulmonares que incluíam hemocultura, sorologia para Chlamydia trachomatis e cultura para Bordetella pertussis em swab nasofaríngeo. O estudo foi aprovado pelas Comissões de Pesquisa e Ética do Departamento de Pediatria e de Ética para Análise de Projetos de Pesquisa do HCFMUSP (CAPPesq) e Consentimento Livre e Esclarecido foi obtido junto aos pais ou responsáveis pelas crianças, após exposição dos objetivos da pesquisa e procedimentos aos quais seriam submetidas.

\subsection{Coleta, transporte e processamento das amostras de secreção nasofaríngea}

A amostra de aspirado de secreção nasofaríngea para medida dos mediadores inflamatórios RANTES, sICAM-1, TNF- $\alpha$, IL-6 e IL-10 foi obtida das crianças com idade inferior a 3 meses e ITRI à admissão hospitalar ou adquirida durante a internação na UCINE. Considerou-se como ITRI de 
origem hospitalar a mudança do quadro respiratório 72 horas após a admissão hospitalar ou ITRI que surja após o período de incubação de agente etiológico conhecido, que no caso do VSR é, em média, de 5 dias (Ford-Jones, 1993). O material foi coletado nas primeiras 24 horas de internação do paciente ou por ocasião do diagnóstico de ITRI de origem hospitalar. A coleta de secreção nasofaríngea foi repetida no terceiro e sétimo dias de evolução ou à alta hospitalar (se antes do sétimo dia) apenas nas crianças com infeç̧ão confirmada pelo VSR.

A coleta foi executada, pela própria autora, durante a fisioterapia respiratória de rotina da criança. Com o paciente em posição supina e a cabeça na linha média, sonda siliconizada descartável número seis ou oito foi introduzida até a nasofaringe posterior das crianças. Esta sonda foi conectada a um frasco plástico (Broncozamm ${ }^{\circledR}$, da Zammi Instrumental Ltda.) e este acoplado a uma extensão plástica ligada ao aspirador a vácuo. Foi instilado $0,5 \mathrm{~mL}$ de soro fisiológico em cada narina e posteriormente efetuada a aspiração. $O$ procedimento foi repetido para um total de três alíquotas de soro fisiológico, levando em torno de três minutos para se completar. Todo o procedimento foi realizado de forma estéril, sendo aspirado secreção nasofaríngea em quantidade suficiente para 0 processamento. Durante toda a coleta os pacientes permaneceram sob monitorização cardíaca contínua e oximetria de pulso. Caso ocorresse queda da frequência cardíaca ou da saturação de oxigênio, com presença de cianose durante a aspiração da secreção nasofaríngea, seria fornecido aos pacientes oxigênio inalatório ( $5 \mathrm{~L} /$ minuto) ou se estivessem intubados, 
seria aumentada, naquele momento, a fração inspirada de oxigênio em $10 \%$. Os frascos contendo as amostras coletadas foram identificados, acondicionados em gelo e transportados, de imediato, aos laboratórios específicos.

Um frasco com aproximadamente $1 \mathrm{~mL}$ do material aspirado foi analisado no Laboratório de Vírus Respiratórios do Serviço de Virologia do Instituto Adolfo Lutz de São Paulo no mesmo dia da coleta, utilizando a reação de IFI para detecção rápida do antígeno viral e isolamento em cultura celular, quando o resultado do teste rápido foi negativo para vírus respiratórios. Deste modo, tentou-se reduzir ao máximo os resultados falsonegativos. A pesquisa de vírus respiratórios foi realizada na amostra inicial de secreção nasofaríngea coletada.

Outro frasco com $2 \mathrm{~mL}$ do aspirado de secreção nasofaríngea foi encaminhado ao Laboratório do Instituto da Criança do HCFMUSP para centrifugação imediata a $3000 \mathrm{rpm}$ durante 5 minutos. $\mathrm{O}$ sobrenadante foi fracionado em cinco tubos plásticos do tipo eppendorf com $200 \mu \mathrm{L}$ cada um ou com volumes iguais e congelado a $-70^{\circ} \mathrm{C}$ para determinação posterior da concentração dos mediadores inflamatórios.

\subsection{Exames específicos para vírus respiratórios}

\subsubsection{Reação de imunofluorescência indireta}

As amostras de secreção nasofaríngea coletadas por aspiração foram submetidas a três lavagens sucessivas com PBS (Phosphate Buffered Saline) e as células obtidas com este procedimento foram diluídas em 500 
$\mu \mathrm{L}$ de PBS. A suspensão resultante foi depositada em lâmina de vidro própria para a reação de imunofluorescência. Após a secagem em fluxo laminar, a lâmina foi fixada com acetona a $4^{\circ} \mathrm{C}$ por 10 minutos e incubada, a $37^{\circ} \mathrm{C}$ em câmara úmida por 30 minutos, com $25 \mu \mathrm{L}$ de anticorpos monoclonais específicos para sete vírus respiratórios diferentes (VSR, vírus influenza tipos A e B, PIV tipos 1, 2 e 3 e adenovírus), produzidos pela Chemicon International Inc. (Temecula, Califórnia, EUA). A seguir, a lâmina foi lavada três vezes com PBS e após sua secagem, adicionou-se $25 \mu \mathrm{L}$ de conjugado anti-lgG de camundongo marcado com Isotiocianato de fluoresceína (FITC).

A lâmina foi novamente incubada e lavada da forma descrita anteriormente. Após secagem, a mesma foi montada com glicerina tamponada e examinada ao microscópio de imunofluorescência com epiiluminação (Nikon ${ }^{\circledR}, 100 \mathrm{~W}$ ). Todas as amostras foram lidas por dois observadores diferentes para garantir a precisão do resultado. No caso de dúvida ou disparidade entre os resultados, foi corada uma outra lâmina e realizada nova leitura. Resultados duvidosos foram considerados negativos.

Os padrões positivos de imunofluorescência nas células variam de acordo com os vírus estudados. Para o VSR e PIV observa-se um padrão de imunofluorescência citoplasmático. Antígenos virais produzidos pela replicação dos vírus influenza A e B podem ser identificados no citoplasma e no núcleo da célula. Padrões de imunofluorescência nuclear, citoplasmático e na região da membrana citoplasmática podem ser observados nas células infectadas pelo adenovírus. 
Para identificação dos grupos do VSR foram utilizados anticorpos monoclonais grupo específicos, como o Mab 92-11C para o grupo A (reagem com a proteína de fusão 1 b do VSR) e o Mab 102-10B para o grupo B (reagem com a proteína de fusão $1 \mathrm{c}$ do VSR). Todos os anticorpos monoclonais utilizados foram produzidos pela Chemicon International Inc. (Temecula, Califórnia, EUA).

\subsubsection{Isolamento em cultura celular}

As amostras, previamente tratadas com Penicilina (1000 Ul/mL) e Estreptomicina $(1000 \mu \mathrm{g} / \mathrm{mL})$ para inibir o crescimento de bactérias habituais da flora respiratória, foram inoculadas em tubos contendo culturas celulares de linhagem HEp-2 (carcinoma epidermóide humano), NCI-H292 (carcinoma mucoepidermóide de pulmão humano), MDCK (rim de cão Madin-Darbin) e VERO (rim de macaco Verde Africano). As culturas celulares de linhagem HEp-2 foram mantidas em meio mínimo essencial de EAGLE ao qual adicionou-se $2 \%$ de soro fetal bovino, previamente inativado a $56^{\circ} \mathrm{C}$ por 1 hora, e $20 \mu \mathrm{g} / \mathrm{mL}$ de Gentamicina. Já as culturas celulares de linhagem contínua MDCK foram mantidas em meio mínimo essencial de EAGLE, sem soro, ao qual adicionou-se $25 \mu \mathrm{g} / \mathrm{mL}$ de Tripsina e $20 \mu \mathrm{g} / \mathrm{mL}$ de Gentamicina. Enquanto que as culturas celulares VERO foram mantidas em meio 199, sem soro, ao qual também adicionou-se $25 \mu \mathrm{g} / \mathrm{mL}$ de Tripsina e $20 \mu \mathrm{g} / \mathrm{mL}$ de Gentamicina. Foram inoculados de 0,1 a $0,3 \mathrm{~mL}$ do material biológico em cada tubo e incubados em estufa a $35^{\circ} \mathrm{C}$. As culturas foram examinadas ao microscópio óptico comum a cada 2 dias, por um período de 14 dias, para observação de efeito citopático. As culturas celulares MDCK e 
VERO foram submetidas ao teste de hemaglutinação, para detecção do antígeno viral, frente ao uso de suspensão de hemácias de galinha e cobaio a $0,5 \%$, respectivamente. As amostras foram consideradas negativas após três passagens sucessivas nas culturas celulares. $O$ vírus isolado foi identificado por IFI com anticorpos monoclonais específicos (Respiratory Viruses Panel I Viral Screening \& Identification $\mathrm{Kit}^{\circledR}$, da Chemicon International Inc. (Temecula, Califórnia, EUA).

\subsubsection{Reação em cadeia da polimerase}

Todas as amostras iniciais de secreção nasofaríngea foram transportadas, em gelo seco, para o Laboratório de Virologia Clínica e Molecular do Instituto de Ciências Biomédicas II da USP, onde realizaram a extração de RNA, a reação de transcriptase reversa (cDNA) e a reação em cadeia da polimerase via transcriptase reversa em tempo real (RT-PCR) para a pesquisa do metapneumovírus humano.

\subsection{Medida dos mediadores inflamatórios}

Coletamos $2 \mathrm{~mL}$ de sangue periférico em tubo com gel siliconizado dos pacientes com idade inferior a 3 meses e ITRI. O material foi coletado nas primeiras 24 horas de internação do paciente ou por ocasião do diagnóstico de ITRI de origem hospitalar. A coleta de sangue foi repetida no terceiro e sétimo dias de evolução ou à alta hospitalar (se antes do sétimo dia) apenas nas crianças com infecção pelo VSR. O material foi encaminhado ao Laboratório do Instituto da Criança do HCFMUSP, logo após a coleta, para centrifugação imediata a 3000 rpm durante 5 minutos. 0 
soro obtido foi colocado em cinco tubos do tipo eppendorf com $200 \mu \mathrm{L}$ cada um ou com volumes iguais e congelado $\mathrm{a}-70^{\circ} \mathrm{C}$ até a análise subsequente da concentração dos mediadores inflamatórios (RANTES, sICAM-1, TNF- $\alpha$, IL-6 e IL-10). Todas as medidas das concentrações dos mediadores inflamatórios na secreção nasofaríngea e no soro foram realizadas no Laboratório de Investigação Médica (LIM 36) do Instituto da Criança do HCFMUSP.

As medidas dos mediadores inflamatórios foram realizadas através da técnica quantitativa ELISA (Enzime-Linked Immunosorbent Assay) sanduíche, utilizando-se o kit da R\&D Systems Inc., Minneapolis, EUA. O kit específico para cada mediador inflamatório é composto por 15 placas de microtitulação com 96 câmaras sensibilizadas com um tampão, que contêm o anticorpo monoclonal específico para cada mediador inflamatório a ser detectado. O anticorpo monoclonal ancorado na placa capturou o mediador inflamatório presente em $200 \mu \mathrm{L}$ de sobrenadante de secreção nasofaríngea e de soro descongelados. Após 2 horas e meia de incubação, em temperatura ambiente, e quatro lavagens que removeram substâncias não ligadas, um anticorpo policlonal específico (anticorpo biotinilado), marcado com a enzima peroxidase-estreptavidina, foi adicionado às câmaras. Uma segunda incubação de 2 horas e meia, em temperatura ambiente, foi seguida de mais quatro lavagens que também removeram substâncias não ligadas. A próxima etapa consistiu em adicionar o substrato da enzima (peróxido de hidrogênio) e a substância cremogênica (tetrametilbenzidina ou TMB) às câmaras. A reação foi interrompida com a adição da solução STOP 
(ácido sulfúrico $2 \mathrm{~N}$ ). A absorbância obtida foi diretamente proporcional à concentração do mediador inflamatório presente na amostra, levando à alteração da cor do sobrenadante da secreção nasofaríngea e do soro. A densidade óptica foi determinada por espectrofotometria no comprimento de onda de $450 \mathrm{~nm}$, posteriormente corrigida com leitura de 540 ou $570 \mathrm{~nm}$ devido às distorções ópticas causadas pelo poliestireno da placa de microtitulação.

As análises das concentrações dos mediadores inflamatórios na secreção nasofaríngea e no soro foram realizadas em monoplicatas. De acordo com os fabricantes do kit, os limites inferiores de detecção dos mediadores inflamatórios são os seguintes: RANTES: $8 \mathrm{pg} / \mathrm{mL}$; sICAM-1: $15,6 \mathrm{pg} / \mathrm{mL} ;$ TNF- $\alpha: 4,4 \mathrm{pg} / \mathrm{mL} ; \mathrm{IL}-6: 4,7 \mathrm{pg} / \mathrm{mL} ;$ e IL-10: $3,9 \mathrm{pg} / \mathrm{mL}$. Considerou-se, para fins estatísticos, como concentração mínima detectável de cada mediador inflamatório nas amostras de secreção nasofaríngea e soro o menor valor encontrado à admissão no estudo, no terceiro e no sétimo dias de evolução ou por ocasião da alta hospitalar (se antes do sétimo dia). Os ensaios R\&D ELISA apresentam precisão intraensaio de 1 a $4 \%$ e interensaio de 2 a $7 \%$.

\subsection{Análise estatística}

Os pacientes foram descritos através de variáveis qualitativas e quantitativas que serviram para avaliar a homogeneidade dos grupos. As variáveis qualitativas foram expressas em frequências simples e relativas (porcentagens). As variáveis quantitativas foram resumidas em médias, 
desvios-padrão, medianas com primeiro e terceiro quartis (percentis 25 e 75 , respectivamente), valores mínimos e máximos. Na comparação entre os grupos (crianças com sistema de escore clínico modificado de normal a leve e de moderado a grave), com relação às variáveis qualitativas, foi utilizado o teste qui-quadrado de Pearson ou o teste exato de Fisher, quando havia frequências esperadas menores que 5. Para as variáveis quantitativas com distribuição normal, os grupos foram comparados pelo teste $\mathrm{t}$ de Student. Quando a distribuição não foi normal, utilizou-se a transformação logarítmica. Para a comparação das concentrações dos mediadores inflamatórios entre a secreção nasofaríngea e o soro e entre os grupos A e B do VSR foi utilizado o teste não paramétrico de Mann-Whitney.

Foi investigada a presença de correlação entre as concentrações de mediadores inflamatórios (secreção nasofaríngea e soro) e entre estas concentrações de mediadores inflamatórios e os marcadores de gravidade da doença respiratória pelo VSR (variáveis sob a forma quantitativa) através do coeficiente de correlação de Spearman. Este estudo foi desenhado para identificar associações clinicamente significantes. O tamanho da amostragem $(n=30)$ foi calculado com base nos valores obtidos para as concentrações de RANTES, TNF- $\alpha$ e IL-6 (média e desvio-padrão) por Chung e Kim (2002) e Wang et al. (1999). As concentrações de mediadores inflamatórios na secreção nasofaríngea e no soro nos intervalos de tempo foram analisadas através do teste não paramétrico de Friedman, seguido por comparações múltiplas para localizar as diferenças entre 2 dias de coleta (Armitage e Berry, 1994). O nível de significância adotado foi <0,05. 
O banco de dados foi criado no Excel 2007 e os programas

estatísticos utilizados foram o SPSS for Windows (versão 11) e GraphPad Prism (versão 5).

\subsection{Delineamento do estudo}

O delineamento do estudo pode ser visto na Figura 4.

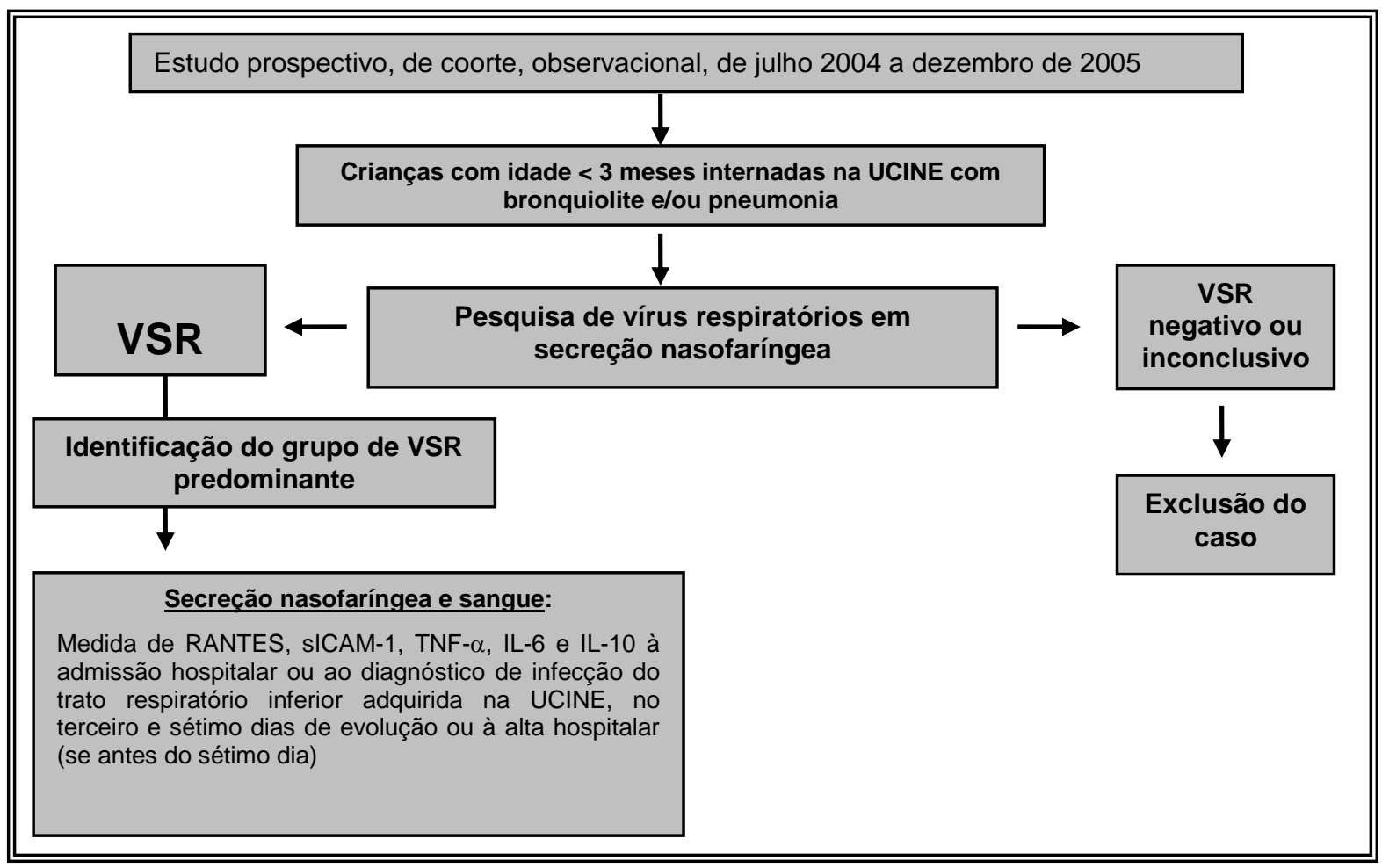

FIGURA 4. Delineamento do estudo 
5

RESULTADOS 


\section{RESULTADOS}

\section{Caracterização dos pacientes}

Dos 30 pacientes com ITRI pelo VSR incluídos no estudo, 20 (67\%) eram do sexo masculino e 10 (33\%) do feminino. A maioria das crianças eram de termo (22 casos, 73\%) e a idade gestacional dos pacientes variou de 33 a 40,5 semanas, com média de 37,7 semanas. O peso de nascimento oscilou de 1495 a 3925 g, com média de 2903 g; enquanto o peso à admissão hospitalar variou de 2000 a 4820 g, com média de 3593 g. A média da idade ao início dos sinais e sintomas foi de 24,3 dias, com variação de 11 a 49 dias, e a idade à admissão oscilou de 12 a 50 dias, com média de 27,7 dias. Nove crianças (30\%) eram portadoras de bronquiolite, três (10\%) de pneumonia e $18(60 \%)$ de bronquiolite associada à pneumonia. De acordo com o sistema de escore clínico modificado de De Boeck et al. (1997) à admissão hospitalar (Dia 1), 16 pacientes (53\%) apresentavam quadro respiratório de normal a leve e 14 (47\%) de moderado a grave, com escore médio de 6,4 e variação de um a 12 . Vinte crianças (67\%) apresentavam sistema de escore clínico modificado de normal a leve no terceiro dia de internação (Dia 3) e 10 (33\%) de moderado a grave, com escore médio de 5,6 e oscilação de um a 12. Vinte e cinco crianças (83\%) apresentavam sistema de escore clínico modificado de normal a leve no sétimo dia de internação (Dia 7) ou à alta hospitalar (se antes do sétimo dia) e cinco (17\%) de moderado a grave, com escore médio de 3,9 e variação de um a 12. A média do tempo de doença à coleta das primeiras amostras de secreção nasofaríngea e de sangue para análise das concentrações dos mediadores inflamatórios foi de 3,4 dias, com 
variação de 1 a 5 dias. A duração do desconforto respiratório foi em média de 12 dias, com variação de 2 a 47 dias. Vinte e seis pacientes (87\%) necessitaram de oxigenoterapia durante a internação na UCINE, com média do tempo de uso de oxigênio suplementar de 8,5 dias e variação de 1 a 43 dias. Dez crianças (33\%) foram submetidas à ventilação mecânica, com média de tempo de 9,7 dias e oscilação de 3 a 32 dias. A duração da internação foi em média de 11,9 dias, com variação de 4 a 50 dias. Não houve óbitos entre os pacientes envolvidos no estudo.

Vinte e nove crianças (97\%) apresentavam ITRI pelo VSR à admissão hospitalar e um paciente (3\%) adquiriu ITRI pelo vírus durante a internação na UCINE. Sete crianças (23\%) necessitaram de hospitalização prévia devido ao quadro respiratório. Antibioticoterapia pregressa pelo quadro respiratório ocorreu em dois pacientes (7\%). Duas crianças (7\%) apresentavam à admissão hospitalar infecção concomitante ao VSR pelos seguintes agentes etiológicos: Chlamydia trachomatis (um caso) e metapneumovírus humano (um caso). Duas crianças $(7 \%)$ evoluíram com sepse por Staphylococcus coagulse negativo oxacilina resistente durante a internação e três (10\%) desenvolveram infecção do trato urinário, sendo dois casos por Escherichia coli e um por Enterococcus faecalis. As características individuais dos 30 pacientes com ITRI pelo VSR encontram-se nos Anexos, bem como as concentrações dos mediadores inflamatórios (RANTES, sICAM-1, TNF-a, IL-6 e IL-10) nas primeiras, segundas e terceiras amostras de secreção nasofaríngea e soro.

Os resultados são apresentados a seguir, sob a forma de tabelas e gráficos. 
TABELA 2 - CARACTERÍSTICAS DAS 30 CRIANÇAS COM IDADE INFERIOR A 3 MESES E ITRI PELO VSR* DISTRIBUÍDAS DE ACORDO COM O SISTEMA DE ESCORE CLÍNICO MODIFICADO À ADMISSÃO NA UCINE (VARIÁVEIS QUALITATIVAS)

\begin{tabular}{|c|c|c|c|}
\hline CARACTERÍSTICAS DAS CRIANÇAS & $\begin{array}{c}\text { NORMAL A } \\
\text { LEVE } \\
(n=16)\end{array}$ & $\begin{array}{c}\text { MODERADO } \\
\text { A GRAVE } \\
(n=14)\end{array}$ & $p$ \\
\hline \multicolumn{4}{|l|}{ Sexo } \\
\hline Masculino & $11(68,8 \%)$ & $9(64,3 \%)$ & \multirow[t]{2}{*}{0,796} \\
\hline Feminino & $5(31,2 \%)$ & $5(35,7 \%)$ & \\
\hline \multicolumn{4}{|l|}{ Classificação } \\
\hline Termo & $12(75,0 \%)$ & $10(71,4 \%)$ & \multirow[t]{2}{*}{$>0,999$} \\
\hline Pré-termo & $4(25,0 \%)$ & $4(28,6 \%)$ & \\
\hline \multicolumn{4}{|l|}{ Cepas do VSR } \\
\hline Grupo A & $13(81,2 \%)$ & $4(28,6 \%)$ & \multirow{3}{*}{$<0,001$} \\
\hline Grupo B & - & $10(71,4 \%)$ & \\
\hline Grupos A e B & $3(18,8 \%)$ & - & \\
\hline \multicolumn{4}{|l|}{ Necessidade de oxigenoterapia } \\
\hline $\operatorname{Sim}$ & $12(75,0 \%)$ & $14(100,0 \%)$ & \multirow[t]{2}{*}{0,103} \\
\hline Não & $4(25,0 \%)$ & - & \\
\hline \multicolumn{4}{|l|}{ Necessidade de ventilação mecânica } \\
\hline Sim & - & $10(71,4 \%)$ & \multirow[t]{2}{*}{$<0,001$} \\
\hline Não & $16(100,0 \%)$ & $4(28,6 \%)$ & \\
\hline \multicolumn{4}{|l|}{ Tipo de doença respiratória } \\
\hline Bronquiolite & $6(37,5 \%)$ & $3(21,4 \%)$ & \multirow{3}{*}{0,547} \\
\hline Pneumonia & $1(6,3 \%)$ & $2(14,3 \%)$ & \\
\hline Bronquiolite e pneumonia & $9(56,2 \%)$ & $9(64,3 \%)$ & \\
\hline \multicolumn{4}{|l|}{ Padrão radiológico } \\
\hline Intersticial & $15(93,8 \%)$ & $10(71,4 \%)$ & \multirow{3}{*}{0,157} \\
\hline Alveolar & - & - & \\
\hline Misto & $1(6,2 \%)$ & $4(28,6 \%)$ & \\
\hline
\end{tabular}

Houve associação estatisticamente significante entre as crianças com ITRI pelo VSR de moderada a grave, de acordo com o sistema de escore clínico modificado à admissão hospitalar, e necessidade de ventilação mecânica $(p<0,001)$ e infecção pelo grupo $B$ do vírus $(p<0,001)$. 
TABELA 3 - CARACTERÍSTICAS DAS 30 CRIANÇAS COM IDADE INFERIOR A 3 MESES E ITRI PELO VSR ${ }^{\star}$ DISTRIBUÍDAS DE ACORDO COM O SISTEMA DE ESCORE CLÍNICO MODIFICADO À ADMISSÃO NA UCINE (VARIÁVEIS QUANTITATIVAS)

\begin{tabular}{|c|c|c|c|}
\hline $\begin{array}{c}\text { CARACTERÍSTICAS DAS } \\
\text { CRIANÇAS }\end{array}$ & $\begin{array}{c}\text { NORMAL A } \\
\text { LEVE } \\
(n=16) \\
\end{array}$ & $\begin{array}{c}\text { MODERADO A } \\
\text { GRAVE } \\
(\mathrm{n}=14)\end{array}$ & $p$ \\
\hline \multicolumn{4}{|l|}{ Idade gestacional (semanas) } \\
\hline Média \pm DP & $37,9 \pm 1,8$ & $37,5 \pm 2,3$ & 0,649 \\
\hline Mediana (Q1 - Q3) & $38(36,2-39)$ & $38,2(35,8-39,3)$ & \\
\hline Mínimo - Máximo & $34-40,5$ & $33-40$ & \\
\hline \multicolumn{4}{|l|}{ Peso ao nascimento (gramas) } \\
\hline Média \pm DP & $2845 \pm 483,9$ & $2969 \pm 711,2$ & 0,588 \\
\hline Mediana (Q1 - Q3) & $\begin{array}{l}2883(2495- \\
3165)\end{array}$ & $\begin{array}{l}3193(2400- \\
3500)\end{array}$ & \\
\hline Mínimo - Máximo & $2010-3925$ & $1495-3900$ & \\
\hline \multicolumn{4}{|l|}{ Peso à admissão (gramas) } \\
\hline Média \pm DP & $3543 \pm 763,6$ & $3649 \pm 621,2$ & 0,679 \\
\hline Mediana (Q1 - Q3) & $\begin{array}{c}3605(2931- \\
4176)\end{array}$ & $\begin{array}{c}3758(3166- \\
4100)\end{array}$ & \\
\hline Mínimo - Máximo & $2000-4820$ & $2600-4705$ & \\
\hline \multicolumn{4}{|c|}{ Idade ao início dos sintomas (dias) } \\
\hline Média \pm DP & $23,1 \pm 8,7$ & $25,6 \pm 4,9$ & 0,531 \\
\hline Mediana (Q1 - Q3) & $\begin{array}{c}22,5(17,5- \\
27,8)\end{array}$ & $26(14,5-32,8)$ & \\
\hline Mínimo - Máximo & $11-45$ & $12-49$ & \\
\hline \multicolumn{4}{|l|}{ Idade à admissão (dias) } \\
\hline Média \pm DP & $26,2 \pm 9,4$ & $29,1 \pm 10,7$ & 0,315 \\
\hline Mediana (Q1 - Q3) & $27(19,2-30,8)$ & $29(18,8-35,8)$ & \\
\hline Mínimo - Máximo & $12-50$ & $16-50$ & \\
\hline \multicolumn{4}{|c|}{$\begin{array}{l}\text { Tempo de doença à 1a amostra } \\
\text { coletada de secreção nasofaríngea } \\
\text { e sangue (dias) }\end{array}$} \\
\hline Média \pm DP & $3,1 \pm 1,7$ & $3,6 \pm 1,4$ & 0,376 \\
\hline Mediana (Q1 - Q3) & $3(1-5)$ & $4(2,8-5)$ & \\
\hline Mínimo - Máximo & $1-5$ & $1-5$ & \\
\hline \multicolumn{4}{|l|}{$\begin{array}{l}\text { Duração do desconforto } \\
\text { respiratório (dias) }\end{array}$} \\
\hline Média \pm DP & $8,4 \pm 4,5$ & $16,1 \pm 10,8$ & 0,009 \\
\hline Mediana (Q1 - Q3) & $9(3,5-12)$ & $14(8,5-19,5)$ & \\
\hline Mínimo - Máximo & $2-17$ & $5-47$ & \\
\hline
\end{tabular}


TABELA 3 - CARACTERÍSTICAS DAS 30 CRIANÇAS COM IDADE INFERIOR A 3 MESES E ITRI PELO VSR* DISTRIBUÍDAS DE ACORDO COM O SISTEMA DE ESCORE CLÍNICO MODIFICADO À ADMISSÃO NA UCINE (VARIÁVEIS QUANTITATIVAS)

\begin{tabular}{|c|c|c|c|}
\hline $\begin{array}{c}\text { CARACTERÍSTICAS DAS } \\
\text { CRIANÇAS }\end{array}$ & $\begin{array}{l}\text { NORMAL A } \\
\text { LEVE } \\
(\mathrm{n}=16) \\
\end{array}$ & $\begin{array}{c}\text { MODERADO A } \\
\text { GRAVE } \\
(n=14)\end{array}$ & $\mathrm{p}$ \\
\hline Tempo de oxigenoterapia (dias) & $\mathrm{n}=12$ & $n=14$ & \\
\hline Média \pm DP & $4,6 \pm 3,2$ & $11,9 \pm 10,2$ & 0,006 \\
\hline Mediana (Q1 - Q3) & $4,5(2-6,5)$ & $10(6,2-14,5)$ & \\
\hline Mínimo - Máximo & $1-11$ & $2-43$ & \\
\hline $\begin{array}{l}\text { Tempo de ventilação mecânica } \\
\text { (dias) }\end{array}$ & $\mathrm{n}=\mathbf{0}$ & $n=10$ & \\
\hline Média \pm DP & - & $9,7 \pm 8,9$ & \\
\hline Mediana (Q1 - Q3) & - & $6,5(3-12,5)$ & \\
\hline Mínimo - Máximo & - & $3-32$ & \\
\hline \multicolumn{4}{|l|}{ Duração da internação (dias) } \\
\hline Média \pm DP & $8 \pm 3,3$ & $16,4 \pm 11$ & $<0,001$ \\
\hline Mediana (Q1 - Q3) & $7,5(5,2-10,8)$ & $14(9-18)$ & \\
\hline Mínimo - Máximo & $4-14$ & $8-50$ & \\
\hline
\end{tabular}

Verificou-se que a duração do desconforto respiratório, o tempo de oxigenoterapia e a duração da internação foram maiores nas crianças com ITRI pelo VSR e sistema de escore clínico modificado de moderado a grave à admissão na UCINE, de forma estatisticamente significante $(p=0,009$, $p=0,006$ e $p<0,001$, respectivamente) (Tabela 3). 
TABELA 4 A - CORRELAÇÕES DE SPEARMAN ENTRE AS CONCENTRAÇÕES DE MEDIADORES INFLAMATÓRIOS NAS PRIMEIRAS, SEGUNDAS E TERCEIRAS AMOSTRAS DE SECREÇÃO RESPIRATÓRIA E SORO E OS MARCADORES CLÍNICOS DE GRAVIDADE DA ITRI PELO VSR*

\begin{tabular}{|c|c|c|c|}
\hline $\begin{array}{l}\text { CONCENTRAÇÕES DE } \\
\text { MEDIADORES } \\
\text { INFLAMATÓRIOS }\end{array}$ & $\begin{array}{c}\text { SISTEMA DE } \\
\text { ESCORE CLíNICO } \\
\text { MODIFICADO - } \\
\text { Dia } 1 \\
(n=30)\end{array}$ & $\begin{array}{c}\text { SISTEMA DE } \\
\text { ESCORE CLÍNICO } \\
\text { MODIFICADO - } \\
\text { Dia } 3 \\
(\mathrm{n}=30)\end{array}$ & $\begin{array}{c}\text { SISTEMA DE } \\
\text { ESCORE CLíNICO } \\
\text { MODIFICADO - } \\
\text { Dia } 7 \text { ou à alta } \\
(n=30)\end{array}$ \\
\hline \multicolumn{4}{|l|}{$\begin{array}{l}\text { RANTES (pg/mL) - } \\
\text { secreção nasofaríngea }\end{array}$} \\
\hline$r$ & 0,325 & 0,339 & 0,325 \\
\hline $\mathrm{p}$-valor & 0,079 & 0,067 & 0,080 \\
\hline
\end{tabular}

RANTES (pg/mL) - soro

\begin{tabular}{lccc}
$r$ & 0,057 & 0,104 & 0,157 \\
p-valor & 0,765 & 0,583 & 0,409 \\
\hline $\begin{array}{l}\text { sICAM-1 }(\mathrm{pg} / \mathrm{mL}) \text { - } \\
\text { secreção nasofaríngea }\end{array}$ & & & \\
\hline $\mathrm{r}$ & 0,401 & 0,177 & 0,136 \\
$\mathrm{p}$ & 0,028 & 0,350 & 0,475
\end{tabular}

sICAM-1 $(\mathrm{pg} / \mathrm{mL})$ - soro

$\begin{array}{lll}r & (0,031) & 0,009\end{array}$

p-valor

0,871

0,961

0,354

TNF- $\alpha(p g / m L)-$

secreção nasofaríngea
$r$
0,120
0,051
0,313

p-valor

0,527

0,790

0,093

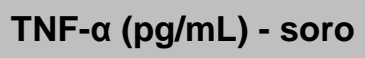

$\begin{array}{llll}r & (0,113) & (0,130) & 0,041 \\ \text { p-valor } & 0,552 & 0,450 & 0,830\end{array}$




\section{TABELA 4 A - CORRELAÇÕES DE SPEARMAN ENTRE AS CONCENTRAÇÕES DE MEDIADORES INFLAMATÓRIOS NAS PRIMEIRAS, SEGUNDAS E TERCEIRAS AMOSTRAS DE SECREÇÃO RESPIRATÓRIA E SORO E OS MARCADORES CLÍNICOS DE GRAVIDADE DA ITRI PELO VSR*}

\begin{tabular}{|c|c|c|c|}
\hline $\begin{array}{c}\text { CONCENTRAÇÕES DE } \\
\text { MEDIADORES } \\
\text { INFLAMATÓRIOS }\end{array}$ & $\begin{array}{c}\text { SISTEMA DE } \\
\text { ESCORE CLÍNICO } \\
\text { MODIFICADO - } \\
\text { Dia } 1 \\
(\mathrm{n}=30)\end{array}$ & $\begin{array}{c}\text { SISTEMA DE } \\
\text { ESCORE CLÍNICO } \\
\text { MODIFICADO - } \\
\text { Dia } 3 \\
(\mathrm{n}=30)\end{array}$ & $\begin{array}{c}\text { SISTEMA DE } \\
\text { ESCORE CLÍNICO } \\
\text { MODIFICADO - } \\
\text { Dia } 7 \text { ou à alta } \\
(\mathrm{n}=30)\end{array}$ \\
\hline \multicolumn{4}{|l|}{$\begin{array}{l}\text { IL-6 }(\mathrm{pg} / \mathrm{mL}) \text { - secreção } \\
\text { nasofaríngea }\end{array}$} \\
\hline$r$ & 0,317 & $(0,114)$ & 0,164 \\
\hline $\mathrm{p}$-valor & 0,088 & 0,549 & 0,386 \\
\hline
\end{tabular}

\begin{tabular}{lccc} 
IL-6 $(\mathbf{p g} / \mathbf{m L})$ - soro & & & \\
\hline$r$ & 0,469 & 0,359 & 0,138 \\
p-valor & 0,009 & 0,051 & 0,466 \\
$\begin{array}{l}\text { IL-10 }(\mathbf{p g} / \mathbf{m L}) \text { - secreção } \\
\text { nasofaríngea }\end{array}$ & & & \\
\hline r & 0,412 & 0,142 & 0,095 \\
p-valor & 0,024 & 0,454 & 0,619
\end{tabular}

$\mathrm{IL}-10(\mathrm{pg} / \mathrm{mL})$ - soro

$\begin{array}{lccc}r & (0,099) & (0,181) & (0,077) \\ \text { p-valor } & 0,604 & 0,338 & 0,684\end{array}$

*ITRI pelo VSR= infecção do trato respiratório inferior vírus sincicial respiratório; r= Coeficiente de correlação de Spearman

conclusão

Na análise das correlações entre o sistema de escore clínico modificado no dia 1 e as concentrações dos mediadores inflamatórios na secreção nasofaríngea e no soro (primeiras amostras) dos pacientes com ITRI pelo VSR, houve correlação positiva significante com sICAM-1 $(r=0,401, p=0,028)$ e IL-10 ( $r=0,412$, $p=0,024)$ na secreção nasofaríngea e com IL-6 ( $r=0,469, p=0,009)$ no soro (Tabela 
4A). Correlações significantes não foram observadas entre o sistema de escore clínico modificado nos dias 3 e 7 ou à alta hospitalar e as concentrações dos mediadores inflamatórios na secreção nasofaríngea e no soro (segundas e terceiras amostras, respectivamente) (Tabela 4A).

Para corrigir qualquer variação dilucional entre as amostras, os resultados foram também expressos em razões de mediadores inflamatórios. Não houve correlações significantes entre o sistema de escore clínico modificado no dia 1 e as razões dos mediadores inflamatórios na secreção nasofaríngea (primeiras amostras). Quanto à análise entre o sistema de escore clínico modificado no dia 1 e as razões dos mediadores inflamatórios no soro (primeiras amostras), verificaram-se correlações negativas significantes com IL-10/L-6 $(r=-0,533$, $p=0,002)$, sICAM-1/LL-6 $(r=-0,439, p=0,015)$ e RANTES/L-6 $(r=-0,408, p=0,025)$, e correlação positiva significante com IL-6/TNF- $\alpha(r=0,561, p=0,001)$.

Em relação à análise das correlações entre o sistema de escore clínico modificado no dia 3 e as razões dos mediadores inflamatórios na secreção nasofaríngea (segundas amostras), houve correlação positiva significante com RANTES/L-10 $(r=0,406, \quad p=0,026)$. Constataram-se correlações positivas significantes entre as razões IL-6/TNF- $\alpha(r=0,676, p<0,001)$ e IL-6/L-10 ( $r=0,624$, $p<0,001)$ e correlações negativas significantes entre as razões RANTES/LL-6 ( $r=$ 0,436, $p=0,016), T N F-\alpha / L-6(r=-0,435, p=0,016)$ e IL-10/LL-6 $(r=-0,412, p=0,024)$ no soro (segundas amostras) e o sistema de escore clínico modificado no dia 3.

Correlações significantes não foram constatadas entre o sistema de escore clínico modificado no dia 7 ou à alta hospitalar e as razões dos mediadores inflamatórios na secreção nasofaríngea e no soro (terceiras amostras). 
TABELA 4B - CORRELAÇÕES DE SPEARMAN ENTRE AS CONCENTRAÇÕES DE MEDIADORES INFLAMATÓRIOS NAS PRIMEIRAS AMOSTRAS DE SECREÇÃO NASOFARÍNGEA E SORO E OS MARCADORES CLÍNICOS DE GRAVIDADE DA ITRI PELO VSR*

\begin{tabular}{l|c|c|c}
\hline \hline $\begin{array}{l}\text { CONCENTRAÇÕES } \\
\begin{array}{l}\text { DE MEDIADORES } \\
\text { INFLAMATÓRIOS }\end{array}\end{array}$ & $\begin{array}{c}\text { TEMPO DE } \\
\text { OXIGENOTERAPIA } \\
(\text { DIAS) } \\
(\mathrm{n}=26)\end{array}$ & $\begin{array}{c}\text { TEMPO DE } \\
\text { VENTILAÇÃO } \\
\text { MECÂNICA } \\
\text { (DIAS) } \\
(\mathrm{n}=10)\end{array}$ & $\begin{array}{c}\text { DURAÇÃO DA } \\
\text { INTERNAÇÃO } \\
\text { (DIAS) } \\
(\mathrm{n}=30)\end{array}$ \\
$\begin{array}{l}\text { RANTES }(\mathrm{pg} / \mathrm{mL}) \text { - } \\
\text { secreção } \\
\text { nasofaríngea }\end{array}$ & & & \\
$\mathrm{r}$ & 0,307 & $(0,253)$ & 0,096 \\
p-valor & 0,128 & 0,470 & 0,614
\end{tabular}

RANTES (pg/mL) -

soro

$\begin{array}{llll}r & 0,077 & (0,025) & 0,113 \\ \text { p-valor } & 0,708 & 0,946 & 0,553\end{array}$

\begin{tabular}{|c|c|c|c|}
\hline $\begin{array}{l}\text { sICAM-1 } \\
\text { secreçã } \\
\text { nasofari }\end{array}$ & & & \\
\hline$r$ & 0,224 & $(0,018)$ & 0,360 \\
\hline $\mathrm{p}$-valor & 0,271 & 0,973 & 0,051 \\
\hline
\end{tabular}

sICAM-1 (pg/mL) -

soro

$\begin{array}{lccc}r & (0,173) & (0,605) & (0,042) \\ p \text {-valor } & 0,397 & 0,067 & 0,827\end{array}$

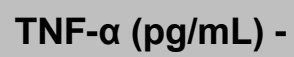 \\ secreção \\ nasofaríngea}

$\begin{array}{llll}r & 0,168 & 0,108 & 0,268 \\ \text { p-valor } & 0,412 & 0,759 & 0,152\end{array}$

TNF- $\alpha(p g / m L)$ - soro

$\begin{array}{lccc}r & (0,148) & (0,118) & 0,036 \\ \text { p-valor } & 0,472 & 0,733 & 0,848\end{array}$


TABELA 4B - CORRELAÇÕES DE SPEARMAN ENTRE AS CONCENTRAÇÕES DE MEDIADORES INFLAMATÓRIOS NAS PRIMEIRAS AMOSTRAS DE SECREÇÃO NASOFARÍNGEA E SORO E OS MARCADORES CLÍNICOS DE GRAVIDADE DA ITRI PELO VSR*

\begin{tabular}{|c|c|c|c|}
\hline $\begin{array}{l}\text { CONCENTRAÇÕES } \\
\text { DE MEDIADORES } \\
\text { INFLAMATÓRIOS }\end{array}$ & $\begin{array}{c}\text { TEMPO DE } \\
\text { OXIGENOTERAPIA } \\
\text { (DIAS) } \\
(\mathrm{n}=26)\end{array}$ & $\begin{array}{c}\text { TEMPO DE } \\
\text { VENTILAÇÃO } \\
\text { MECÂNICA } \\
\text { (DIAS) } \\
(n=10)\end{array}$ & $\begin{array}{l}\text { DURAÇÃO DA } \\
\text { INTERNAÇÃO } \\
\text { (DIAS) } \\
(n=30)\end{array}$ \\
\hline \multicolumn{4}{|l|}{$\begin{array}{l}\text { IL-6 (pg/mL) - } \\
\text { secreção } \\
\text { nasofaríngea }\end{array}$} \\
\hline$r$ & 0,162 & $(0,408)$ & 0,143 \\
\hline $\mathrm{p}$-valor & 0,430 & 0,248 & 0,451 \\
\hline
\end{tabular}

IL-6 (pg/mL) - soro

$\begin{array}{lccc}r & 0,445 & (0,222) & 0,572 \\ \text { p-valor } & 0,023 & 0,537 & 0,001\end{array}$

\section{IL-10 (pg/mL) - \\ secreção \\ nasofaríngea}
$r$
0,271
$(0,231)$
0,181

p-valor

0,181

0,514

0,337

IL-10 (pg/mL) - soro
$r$
$(0,122)$
$(0,118)$
0,064

p-valor

0,551

0,733

0,735

*ITRI pelo VSR= infecção do trato respiratório inferior vírus sincicial respiratório; r= Coeficiente de correlação de Spearman

conclusão

Verificaram-se correlações positivas significantes entre as concentrações de IL-6 no soro à admissão hospitalar e o tempo de oxigenoterapia $(r=0,445, p=0,023)$ e a duração da internação ( $r=0,572$, $p=0,001$ ) (Tabela 4B). Não houve correlações significantes entre os 
mediadores inflamatórios e suas razões na secreção nasofaríngea à admissão na UCINE (primeiras amostras) e os tempos de oxigenoterapia e de ventilação mecânica e a duração da internação.

$\mathrm{Na}$ análise das correlações entre o tempo de oxigenoterapia e as razões dos mediadores inflamatórios no soro à admissão na UCINE (primeiras amostras), houve correlação positiva significante com IL-6/TNF- $\alpha$ $(r=0,505, p=0,009)$ e correlações negativas significantes com IL-10/IL-6 ( $r=-$ $0,465, p=0,017)$ e sICAM-1/IL-6 $(r=-0,425, p=0,031)$.

Correlações significantes não foram verificadas entre o tempo de ventilação mecânica e as razões dos mediadores inflamatórios no soro à admissão hospitalar (primeiras amostras).

No que se refere às correlações entre a duração da internação na UCINE e as razões dos mediadores inflamatórios no soro (primeiras amostras), ocorreram correlações negativas significantes com IL-10/IL-6 ( $r=-$ 0,590, $p<0,001)$, sICAM-1/IL-6 $(r=-0,546, p=0,002)$ e RANTES/IL-6 ( $r=-$ 0,487, $p=0,006)$, e correlação positiva significante com IL-6/TNF- $\alpha(r=0,532$, $p=0,002)$. 


\section{GRÁFICO 1 - FREQUÊNCIA DOS GRUPOS DE VÍRUS SINCICIAL RESPIRATÓRIO EM 30 CRIANÇAS COM IDADE INFERIOR A 3 MESES E INFECÇÃO DO TRATO RESPIRATÓRIO INFERIOR INTERNADAS NA UCINE - JUL 2004 - DEZ 2005}

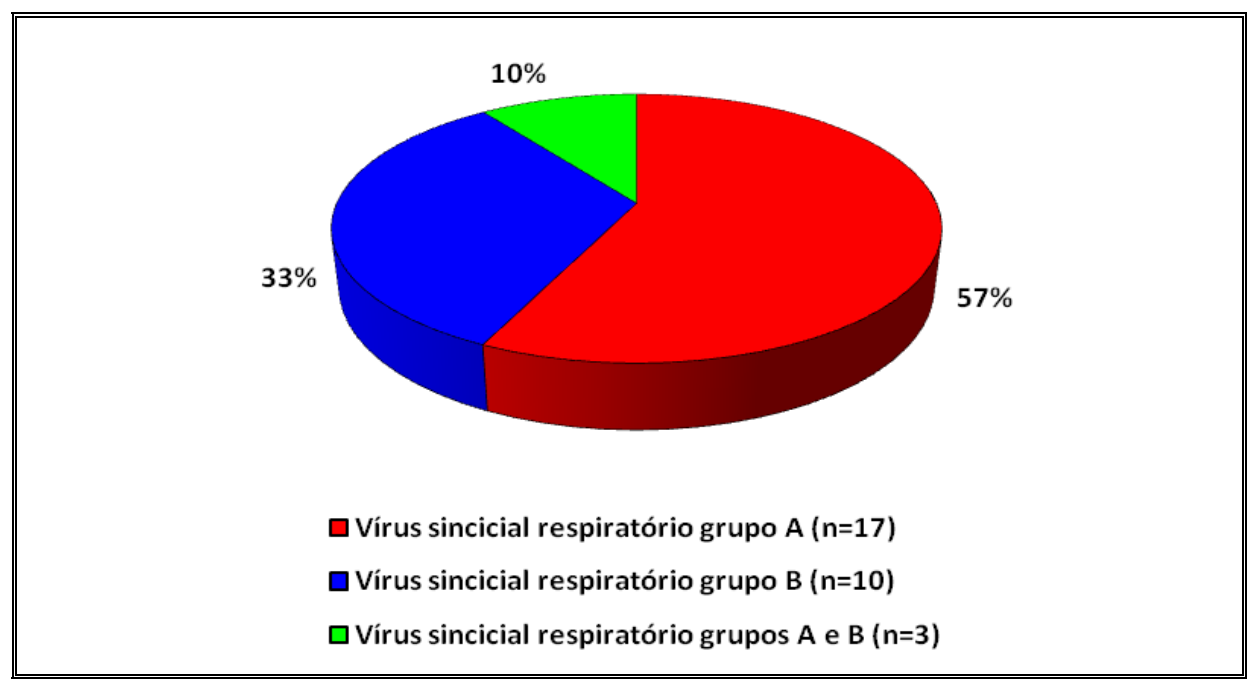

Dos 30 casos de VSR identificados, 20 (67\%) foram no outono, sendo $13(65 \%)$ do grupo A e sete (35\%) do grupo B do vírus. Oito casos (27\%) de VSR ocorreram no inverno, sendo dois do grupo $A$, três do grupo $B$ e três dos grupos A e B do vírus. Dois casos (7\%) de VSR foram detectados no verão, sendo do grupo A do vírus.

As infecções pelas cepas do grupo B do VSR (10 casos) foram mais graves do que aquelas do grupo A (17 casos). Oito das 10 crianças com ITRI pelo grupo B do VSR necessitaram de ventilação mecânica durante a internação na UCINE, enquanto nenhuma com ITRI pelo grupo A do vírus necessitou ser intubada $(p<0,001)$. Não houve diferença estatisticamente significante entre os dois grupos de VSR em relação à necessidade de oxigenoterapia (13 casos no grupo $A$ e 10 no grupo $B, p=0,264$ ), ao tempo de oxigenoterapia (média de 5,1 dias no grupo $A$ e 8,8 dias no grupo $B$, $\mathrm{p}=0,122$ ) e à duração da internação (média de 9 dias no grupo $\mathrm{A}$ e 11,9 dias no grupo $B, p=0,289)$. 


\section{TABELA 5A - COMPARAÇÃO ENTRE AS MEDIANAS DAS CONCENTRAÇÕES DOS MEDIADORES INFLAMATÓRIOS NAS PRIMEIRAS AMOSTRAS DE SECREÇÃO NASOFARÍNGEA E SORO DAS 30 CRIANÇAS COM IDADE INFERIOR A 3 MESES E ITRI PELO VSR ${ }^{\star}$}

\begin{tabular}{|c|c|c|c|}
\hline $\begin{array}{c}\text { CONCENTRAÇÕES DOS } \\
\text { MEDIADORES } \\
\text { INFLAMATÓRIOS } \\
\end{array}$ & $\begin{array}{c}\text { SECREÇÃO } \\
\text { NASOFARINGGA } \\
(n=30)\end{array}$ & $\begin{array}{l}\text { SORO } \\
(n=30)\end{array}$ & $p$ \\
\hline \multicolumn{4}{|l|}{ RANTES (pg/mL) } \\
\hline Média \pm DP & $342 \pm 304,2$ & $799,5 \pm 132,4$ & \multirow{3}{*}{$<0,001$} \\
\hline Mediana (Q1 - Q3) & $240,8(98,8-554,4)$ & $842,7(764,8-878,4)$ & \\
\hline Mínimo - Máximo & $31,6-1050,4$ & $462-981,7$ & \\
\hline \multicolumn{4}{|l|}{ sICAM-1 (pg/mL) } \\
\hline Média \pm DP & $846,9 \pm 442,7$ & $1558,9 \pm 98,5$ & \multirow{3}{*}{$<0,001$} \\
\hline Mediana (Q1 - Q3) & 774,7 (529 - 1062) & $1573,3(1513-1631)$ & \\
\hline Mínimo - Máximo & $255,7-2352,2$ & $1324,7-1733,2$ & \\
\hline \multicolumn{4}{|l|}{ TNF- $\alpha(p g / m L)$} \\
\hline Média \pm DP & $195,3 \pm 380,4$ & $13,3 \pm 26,8$ & \multirow{3}{*}{$<0,001$} \\
\hline Mediana (Q1 - Q3) & $41,1(12,5-258,1)$ & $4,4(4,4-4,4)$ & \\
\hline Mínimo - Máximo & $12,5-2031,4$ & $4,4-127,5$ & \\
\hline \multicolumn{4}{|l|}{ IL-6 (pg/mL) } \\
\hline Média \pm DP & $260,3 \pm 203,4$ & $54,9 \pm 134,2$ & \multirow{3}{*}{$<0,001$} \\
\hline Mediana (Q1 - Q3) & $209,4(138,9-325)$ & $11,6(7,5-41,4)$ & \\
\hline Mínimo - Máximo & $30,5-1064,7$ & $7,5-723,9$ & \\
\hline \multicolumn{4}{|l|}{ IL-10 (pg/mL) } \\
\hline Média \pm DP & $65,1 \pm 155,4$ & $65 \pm 42$ & \multirow{3}{*}{$<0,001$} \\
\hline Mediana (Q1 - Q3) & $11,9(11,9-57,4)$ & $53(53-53)$ & \\
\hline Mínimo - Máximo & $11,9-850,3$ & $53-258,6$ & \\
\hline
\end{tabular}

As medianas das concentrações de RANTES, sICAM-1 e IL-10 medidas no soro (primeiras amostras) das crianças com infecção pelo VSR foram maiores do que aquelas na secreção nasofaríngea, de forma estatisticamente significante $(p<0,001, p<0,001$ e $p<0,001$, respectivamente). Enquanto as medianas das concentrações de IL-6 e TNF- $\alpha$ na secreção nasofaríngea (primeiras amostras) foram significantemente mais elevadas $(p<0,001$ e $p<0,001$, respectivamente) (Tabela $5 A)$. 


\section{TABELA 5B - COMPARAÇÃO ENTRE AS MEDIANAS DAS CONCENTRAÇÕES DOS MEDIADORES INFLAMATÓRIOS NAS SEGUNDAS AMOSTRAS DE SECREÇÃO NASOFARÍNGEA E SORO DAS 30 CRIANÇAS COM IDADE INFERIOR A 3 MESES E ITRI PELO VSR ${ }^{\star}$}

\begin{tabular}{|c|c|c|c|}
\hline $\begin{array}{c}\text { CONCENTRAÇÕES DOS } \\
\text { MEDIADORES } \\
\text { INFLAMATÓRIOS }\end{array}$ & $\begin{array}{c}\text { SECREÇ̃̃O } \\
\text { NASOFARINGEA } \\
(n=30)\end{array}$ & $\begin{array}{l}\text { SORO } \\
(n=30)\end{array}$ & $\mathrm{p}$ \\
\hline \multicolumn{4}{|l|}{ RANTES (pg/mL) } \\
\hline Média \pm DP & $208,1 \pm 223,7$ & $778,5 \pm 162,4$ & \multirow{3}{*}{$<0,001$} \\
\hline Mediana (Q1 - Q3) & $132,9(46,9-274,1)$ & $827,4(677,8-896,9)$ & \\
\hline Mínimo - Máximo & $14,6-941,8$ & $448,8-983,7$ & \\
\hline \multicolumn{4}{|l|}{ sICAM-1 (pg/mL) } \\
\hline Média \pm DP & $630,4 \pm 346,8$ & $1512,9 \pm 130$ & \multirow{3}{*}{$<0,001$} \\
\hline Mediana (Q1 - Q3) & $598,2(331,3-922)$ & $1517,1(1443-1595)$ & \\
\hline Mínimo - Máximo & $72,8-1197,9$ & $1228-1723,3$ & \\
\hline \multicolumn{4}{|l|}{ TNF- $\alpha(p g / m L)$} \\
\hline Média \pm DP & $88,5 \pm 153,3$ & $27,5 \pm 16,7$ & \multirow{3}{*}{0,558} \\
\hline Mediana (Q1 - Q3) & $35,1(10,9-91,6)$ & $22,7(22,7-22,7)$ & \\
\hline Mínimo - Máximo & $10,9-754,8$ & $22,7-100,3$ & \\
\hline \multicolumn{4}{|l|}{ IL-6 (pg/mL) } \\
\hline Média \pm DP & $216,6 \pm 115,8$ & $16,7 \pm 25,3$ & \multirow{3}{*}{$<0,001$} \\
\hline Mediana (Q1 - Q3) & $214,7(156,3-281,1)$ & $4,9(4,9-15,6)$ & \\
\hline Mínimo - Máximo & $31,9-620,4$ & $4,9-100,2$ & \\
\hline \multicolumn{4}{|l|}{ IL-10 (pg/mL) } \\
\hline Média \pm DP & $9,8 \pm 10,7$ & $37 \pm 53,9$ & \multirow{3}{*}{$<0,001$} \\
\hline Mediana (Q1 - Q3) & $6,8(6,8-7,2)$ & $16,4(16,4-16,4)$ & \\
\hline Mínimo - Máximo & $6,8-64,2$ & $16,4-228$ & \\
\hline
\end{tabular}

As medianas das concentrações de RANTES, sICAM-1 e IL-10 aferidas no soro (segundas amostras) das crianças com ITRI pelo VSR foram significantemente mais elevadas ( $p<0,001, p<0,001$ e $p<0,001$, respectivamente). No que se refere à mediana das concentrações de IL-6 na secreção nasofaríngea (segundas amostras) destas crianças, esta foi significantemente maior $(p<0,001)$. Não houve diferença estatisticamente significante entre as medianas das concentrações de TNF- $\alpha$ na secreção nasofaríngea e no soro das crianças desta casuística (segundas amostras) (Tabela 5B). 


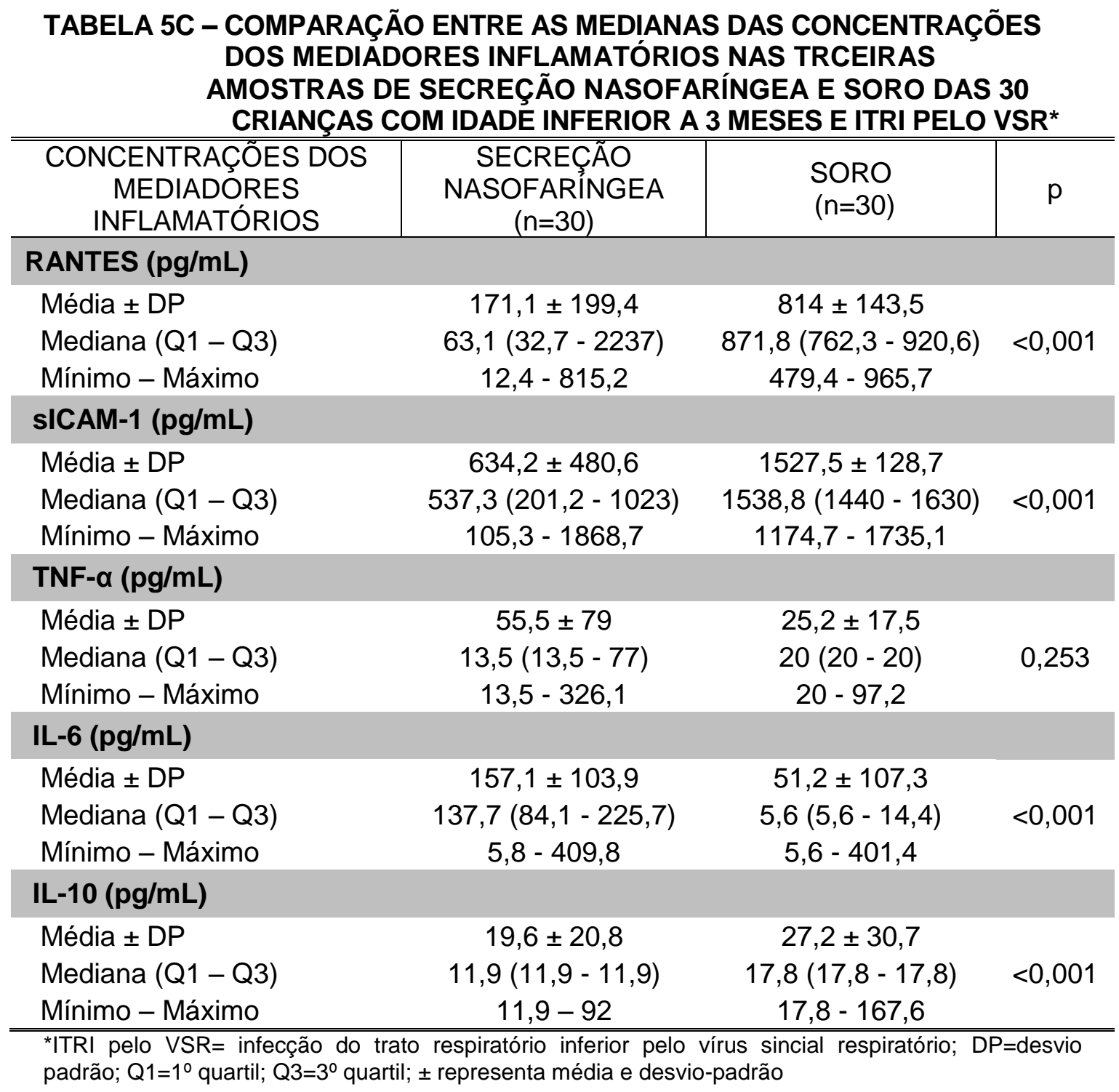

As medianas das concentrações de RANTES, sICAM-1 e IL-10 aferidas no soro (terceiras amostras) das crianças com infecção pelo VSR foram mais elevadas do que aquelas na secreção nasofaríngea, de forma estatisticamente significante $(p<0,001$, $p<0,001$ e $p<0,001$, respectivamente). Enquanto a mediana das concentrações de IL-6 na secreção nasofaríngea (terceiras amostras) destas crianças foi significantemente maior $(p<0,001)$. Não houve diferença estatisticamente significante entre as medianas das concentrações de TNF- $\alpha$ na secreção nasofaríngea e no soro das crianças desta casuística (terceiras amostras) (Tabela 5C). 
TABELA 6 - CORRELAÇÕES DE SPEARMAN ENTRE AS CONCENTRAÇÕES DE MEDIADORES INFLAMATÓRIOS NAS PRIMEIRAS, SEGUNDAS E TERCEIRAS AMOSTRAS DE SECREÇÃOO RESPIRATÓRIA E SORO DAS 30 CRIANÇAS COM IDADE INFERIOR A 3 MESES E ITRI PELO VSR ${ }^{\star}$

\begin{tabular}{|c|c|c|c|}
\hline $\begin{array}{l}\text { CONCENTRAÇÕES } \\
\text { DE MEDIADORES } \\
\text { INFLAMATÓRIOS }\end{array}$ & $\begin{array}{c}\text { PRIMEIRAS } \\
\text { AMOSTRAS } \\
\text { DE SECREÇÃO } \\
\text { NASOFARÍNGEA } \\
\text { E SORO } \\
(n=30)\end{array}$ & $\begin{array}{c}\text { SEGUNDAS } \\
\text { AMOSTRAS DE } \\
\text { SECREĈÃO } \\
\text { NASOFARINGEA } \\
\text { E SORO } \\
(\mathrm{n}=30)\end{array}$ & $\begin{array}{c}\text { TERCEIRAS } \\
\text { AMOSTRAS DE } \\
\text { SECREÇÃO } \\
\text { NASOFARINGEA } \\
\text { E SORO } \\
(\mathrm{n}=30)\end{array}$ \\
\hline \multicolumn{4}{|l|}{ RANTES (pg/mL) } \\
\hline r & 0,111 & $(0,128)$ & 0,203 \\
\hline p-valor & 0,560 & 0,500 & 0,281 \\
\hline \multicolumn{4}{|l|}{ sICAM-1 (pg/mL) } \\
\hline r & 0,004 & 0,240 & 0,144 \\
\hline $\mathrm{p}$-valor & 0,983 & 0,201 & 0,448 \\
\hline \multicolumn{4}{|l|}{ TNF- $\alpha(p g / m L)$} \\
\hline r & $(0,097)$ & $(0,230)$ & $(0,276)$ \\
\hline $\mathrm{p}$-valor & 0,609 & 0,222 & 0,139 \\
\hline \multicolumn{4}{|l|}{ IL-6 (pg/mL) } \\
\hline$r$ & 0,213 & $(0,040)$ & 0,139 \\
\hline $\mathrm{p}$-valor & 0,258 & 0,832 & 0,464 \\
\hline \multicolumn{4}{|l|}{ IL-10 (pg/mL) } \\
\hline$r$ & $(0,131)$ & $(0,015)$ & $(0,174)$ \\
\hline p-valor & 0,490 & 0,937 & 0,358 \\
\hline
\end{tabular}

*ITRI pelo VSR= infecção do trato respiratório inferior vírus sincicial respiratório; $r=$ Coeficiente de correlação de Spearman

Correlações significantes não ocorreram entre as concentrações dos mediadores inflamatórios na secreção nasofaríngea e no soro das amostras estudadas (Tabela 6). 


\begin{tabular}{|c|c|c|c|}
\hline $\begin{array}{l}\text { CONCENTRAÇÕES } \\
\text { DOS MEDIADORES } \\
\text { INFLAMATÓRIOS }\end{array}$ & $\begin{array}{c}\text { GRUPO A } \\
\quad(n=17)\end{array}$ & $\begin{array}{l}\text { GRUPO B } \\
\qquad(n=10)\end{array}$ & $\mathrm{p}$ \\
\hline \multicolumn{4}{|l|}{$\begin{array}{l}\text { RANTES }(\mathrm{pg} / \mathrm{mL}) \text { - secreção } \\
\text { nasofaríngea }\end{array}$} \\
\hline Média \pm DP & $281,2 \pm 286,5$ & $500,9 \pm 321,2$ & \\
\hline Mediana (Q1 - Q3) & $173,8(73-349,9)$ & $\begin{array}{c}527,1(185,8- \\
775,1)\end{array}$ & 0,059 \\
\hline Mínimo - Máximo & $31,6-984,5$ & $86,5-1050,4$ & \\
\hline \multicolumn{4}{|l|}{ RANTES (pg/mL) - soro } \\
\hline Média \pm DP & $822,6 \pm 106,4$ & $796,4 \pm 148,9$ & \\
\hline Mediana (Q1 - Q3) & $\begin{array}{c}849,3(794,7- \\
887,1)\end{array}$ & $831(771,4-873,3)$ & 0,422 \\
\hline Mínimo - Máximo & $577-971,2$ & $462-981,7$ & \\
\hline
\end{tabular}

sICAM-1 $(\mathrm{pg} / \mathrm{mL})$ - secreção
nasofaríngea

\begin{tabular}{|c|c|c|c|}
\hline Média — DP & $8101+3781$ & $9639+5898$ & \multirow{3}{*}{0,530} \\
\hline Mediana (Q1 - Q3) & $884,8(504,5-1070)$ & $\begin{array}{c}861,1(537,5- \\
1173)\end{array}$ & \\
\hline Mínimo - Máximo & $255,7-1493,4$ & $284,1-2352,2$ & \\
\hline \multicolumn{4}{|c|}{ sICAM-1 (pg/mL) - soro } \\
\hline Média \pm DP & $1567,3 \pm 108,1$ & $1552,8 \pm 90,6$ & \multirow{3}{*}{0,615} \\
\hline Mediana (Q1 - Q3) & $\begin{array}{c}1583,2(1517- \\
1637)\end{array}$ & $\begin{array}{c}1557,5(1492- \\
1615)\end{array}$ & \\
\hline Mínimo - Máximo & $1324,7-1733,2$ & $1403,6-1691,7$ & \\
\hline \multicolumn{4}{|c|}{$\begin{array}{l}\text { TNF- } \alpha(p g / m L) \text { - secreção } \\
\text { nasofaríngea }\end{array}$} \\
\hline Média \pm DP & $125,8 \pm 180,4$ & $318,6 \pm 615$ & \multirow{3}{*}{0,309} \\
\hline Mediana (Q1 - Q3) & $20,8(12,5-250,1)$ & $\begin{array}{c}118,6(18,7- \\
289,5)\end{array}$ & \\
\hline Mínimo - Máximo & $12,5-596,7$ & $12,5-2031,4$ & \\
\hline \multicolumn{4}{|l|}{ TNF- $\alpha(p g / m L)$ - soro } \\
\hline Média \pm DP & $18,1 \pm 34,2$ & $8 \pm 11,3$ & \multirow{3}{*}{0,598} \\
\hline Mediana (Q1 - Q3) & $4,4(4,4-4,4)$ & $4,4(4,4-4,4)$ & \\
\hline Mínimo - Máximo & $4,4-127,5$ & $4,4-40,1$ & \\
\hline \multicolumn{4}{|c|}{$\begin{array}{l}\text { IL-6 (pg/mL) - secreção } \\
\text { nasofaríngea }\end{array}$} \\
\hline Média \pm DP & $210,6 \pm 136,3$ & $349,8 \pm 294$ & \multirow[b]{2}{*}{0,139} \\
\hline Mediana (Q1 - Q3) & $171,2(85,3-318,4)$ & $\begin{array}{c}244,5(203,8- \\
414,2)\end{array}$ & \\
\hline Mínimo - Máximo & $56,1-464,6$ & $30,5-1064,7$ & tinua \\
\hline
\end{tabular}




\begin{tabular}{|c|c|c|c|}
\hline $\begin{array}{c}\text { CONCENTRAÇÕES DOS } \\
\text { MEDIADORES INFLAMATÓRIOS }\end{array}$ & $\begin{array}{l}\text { GRUPO A } \\
(n=17)\end{array}$ & $\begin{array}{l}\text { GRUPO B } \\
\quad(n=10)\end{array}$ & $p$ \\
\hline \multicolumn{4}{|l|}{ IL-6 (pg/mL) - soro } \\
\hline $\begin{array}{l}\text { Média } \pm \text { DP } \\
\text { Mediana (Q1 - Q3) } \\
\text { Mínimo - Máximo }\end{array}$ & $\begin{array}{c}58 \pm 172,8 \\
7,5(7,5-15,4) \\
7,5-723,9\end{array}$ & $\begin{array}{c}41,8 \pm 59,8 \\
16,9(7,5-49,4) \\
7,5-200,1\end{array}$ & 0,136 \\
\hline \multicolumn{4}{|l|}{$\begin{array}{l}\text { IL-10 (pg/mL) - secreção } \\
\text { nasofaríngea }\end{array}$} \\
\hline $\begin{array}{l}\text { Média } \pm \text { DP } \\
\text { Mediana (Q1 - Q3) } \\
\text { Mínimo - Máximo }\end{array}$ & $\begin{array}{c}31,9 \pm 48,2 \\
11,9(11,9-24,7) \\
11,9-197,2\end{array}$ & $\begin{array}{c}135,5 \pm 255,7 \\
50,8(11,9-129,5) \\
11,9-850,3\end{array}$ & 0,039 \\
\hline \multicolumn{4}{|l|}{ IL-10 (pg/mL) - soro } \\
\hline $\begin{array}{l}\text { Média } \pm \text { DP } \\
\text { Mediana (Q1 - Q3) } \\
\text { Mínimo - Máximo }\end{array}$ & $\begin{array}{c}67,9 \pm 50,2 \\
53(53-53) \\
53-258,6\end{array}$ & $\begin{array}{c}63,7 \pm 34 \\
53(53-53) \\
53-160,3\end{array}$ & 0,655 \\
\hline
\end{tabular}

Comparando-se os grupos A e B do VSR em relação às concentrações dos mediadores inflamatórios nas primeiras amostras de secreção nasofaríngea e soro à admissão na UCINE, verificamos que houve apenas associação estatisticamente significante $(p=0,039)$ entre a mediana das concentrações de IL-10 na secreção nasofaríngea e o grupo B do vírus (Tabela 7).

Não foi possível avaliar a influência do grupos A e B do VSR concomitantes sobre a concentração dos mediadores inflamatórios na secreção nasofaríngea e no soro dos pacientes estudados, devido ao pequeno número de casos $(n=3)$. 
GRÁFICOS 2 E 3 - ANÁLISE NÃO PARAMÉTRICA DOS NÍVEIS MEDIANOS DAS CONCENTRAÇÕES DE RANTES NA SECREÇÃO

NASOFARÍNGEA E NO SORO DE 30 CRIANÇAS COM IDADE INFERIOR A 3 MESES E ITRI PELO VSR: EFEITO DO TEMPO DE EVOLUÇÃO
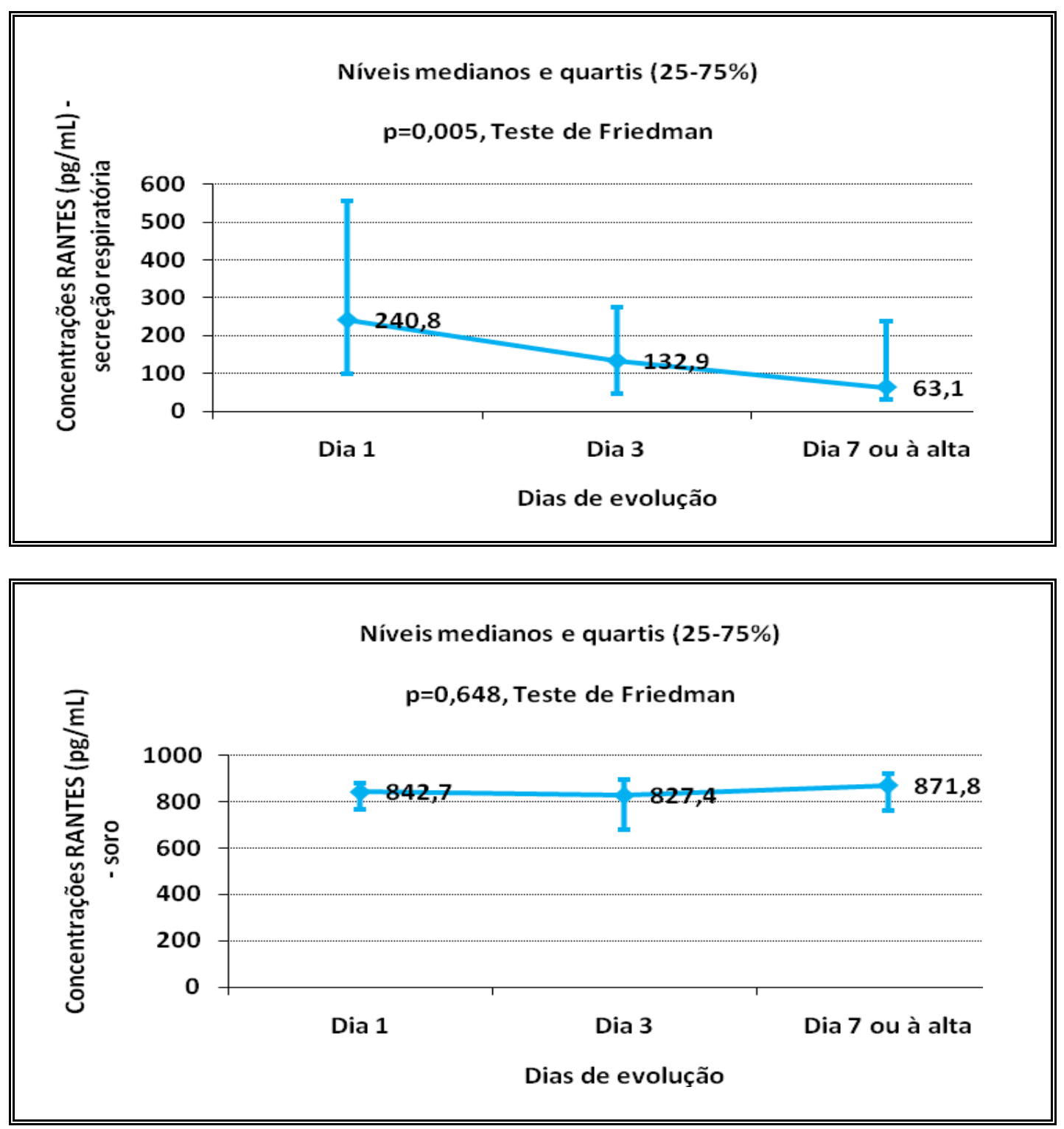

Verificou-se que o efeito do tempo foi significante para RANTES na secreção nasofaríngea das crianças com infecção pelo VSR desta casuística, indicando que existe variação de suas concentrações ao longo dos dias de evolução. Não houve, em nosso estudo, variação significante das concentrações de RANTES no soro, que permaneceram elevadas, durante a evolução da ITRI pelo VSR (Gráficos 2 e 3). 
GRÁFICOS 4 E 5 - ANÁLISE NÃO PARAMÉTRICA DOS NÍVEIS MEDIANOS DAS CONCENTRAÇÕES DE SICAM-1 NA SECREÇÃO

NASOFARÍNGEA E NO SORO DE 30 CRIANÇAS COM IDADE

INFERIOR A 3 MESES E ITRI PELO VSR: EFEITO DO TEMPO

DE EVOLUÇÃO
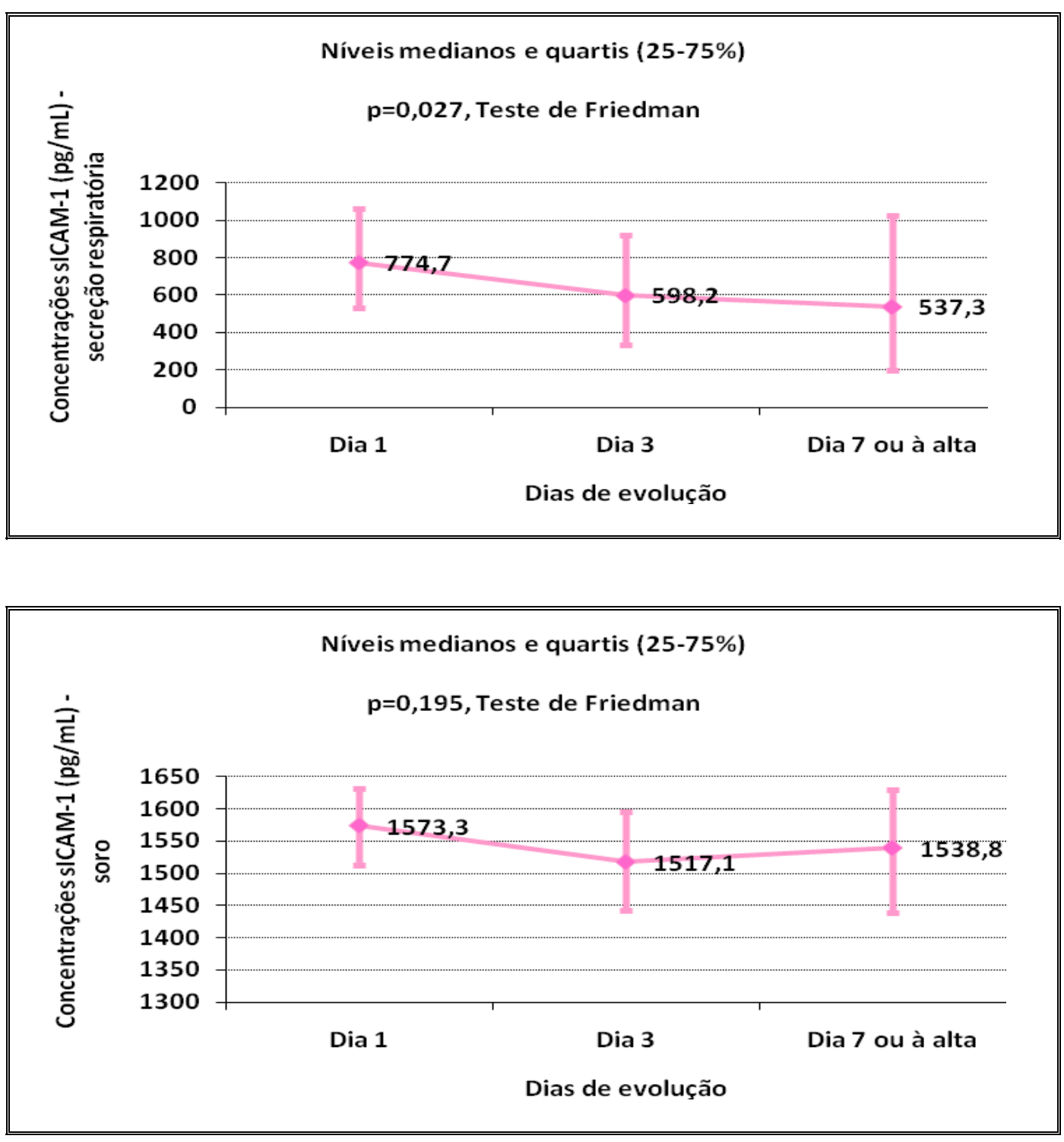

Constatou-se que o efeito do tempo foi significante para sICAM-1 na secreção nasofaríngea das crianças com infecção pelo VSR estudadas, indicando que existe variação das suas concentrações durante a evolução da doença. No entanto, não identificamos variação significante das concentrações de sICAM-1 no soro, que se mantiveram altas, durante a evolução da ITRI pelo VSR (Gráficos 4 e 5). 
GRÁFICOS 6 E 7 - ANÁLISE NÃO PARAMÉTRICA DOS NÍVEIS MEDIANOS DAS CONCENTRAÇÕES DE TNF-a NA SECREÇÃO

NASOFARÍNGEA E NO SORO DE 30 CRIANÇAS COM IDADE INFERIOR A 3 MESES E ITRI PELO VSR: EFEITO DO TEMPO DE EVOLUÇÃO
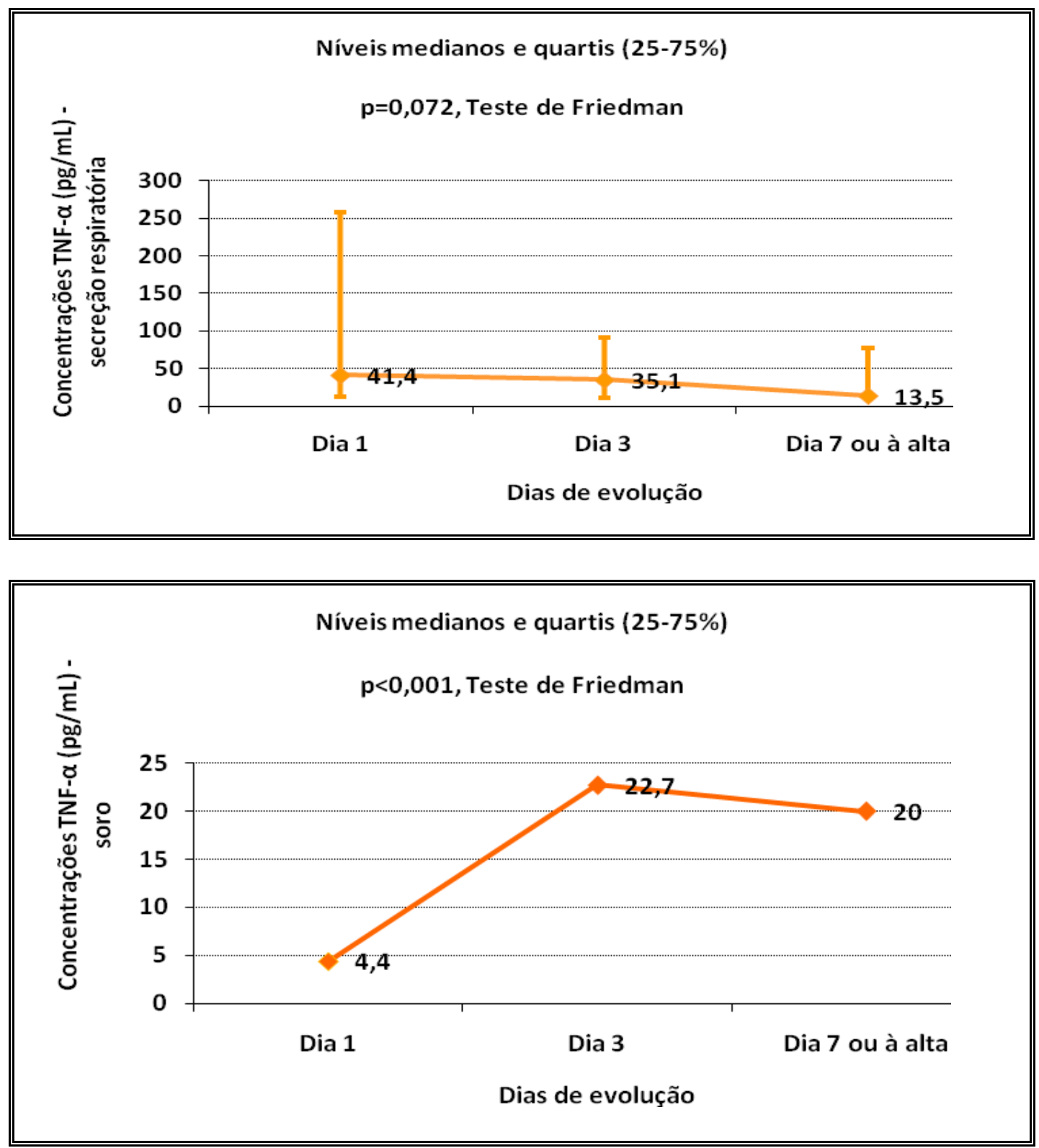

Em nosso estudo não ocorreu variação significante das concentrações de TNF-a na secreção nasofaríngea durante a evolução da ITRI pelo VSR. Verificou-se que o efeito do tempo foi significante para TNF- $\alpha$ no soro das crianças com infecção pelo VSR desta casuística, indicando que existe variação das suas concentrações ao longo dos dias de evolução (Gráficos 6 e 7). 
GRÁFICOS 8 E 9 - ANÁLISE NÃO PARAMÉTRICA DOS NÍVEIS MEDIANOS DAS CONCENTRAÇÕES DE IL-6 NA SECREÇÃO NASOFARÍNGEA

E NO SORO DE 30 CRIANÇAS COM IDADE INFERIOR A 3 MESES E ITRI PELO VSR: EFEITO DO TEMPO DE EVOLUÇÃO
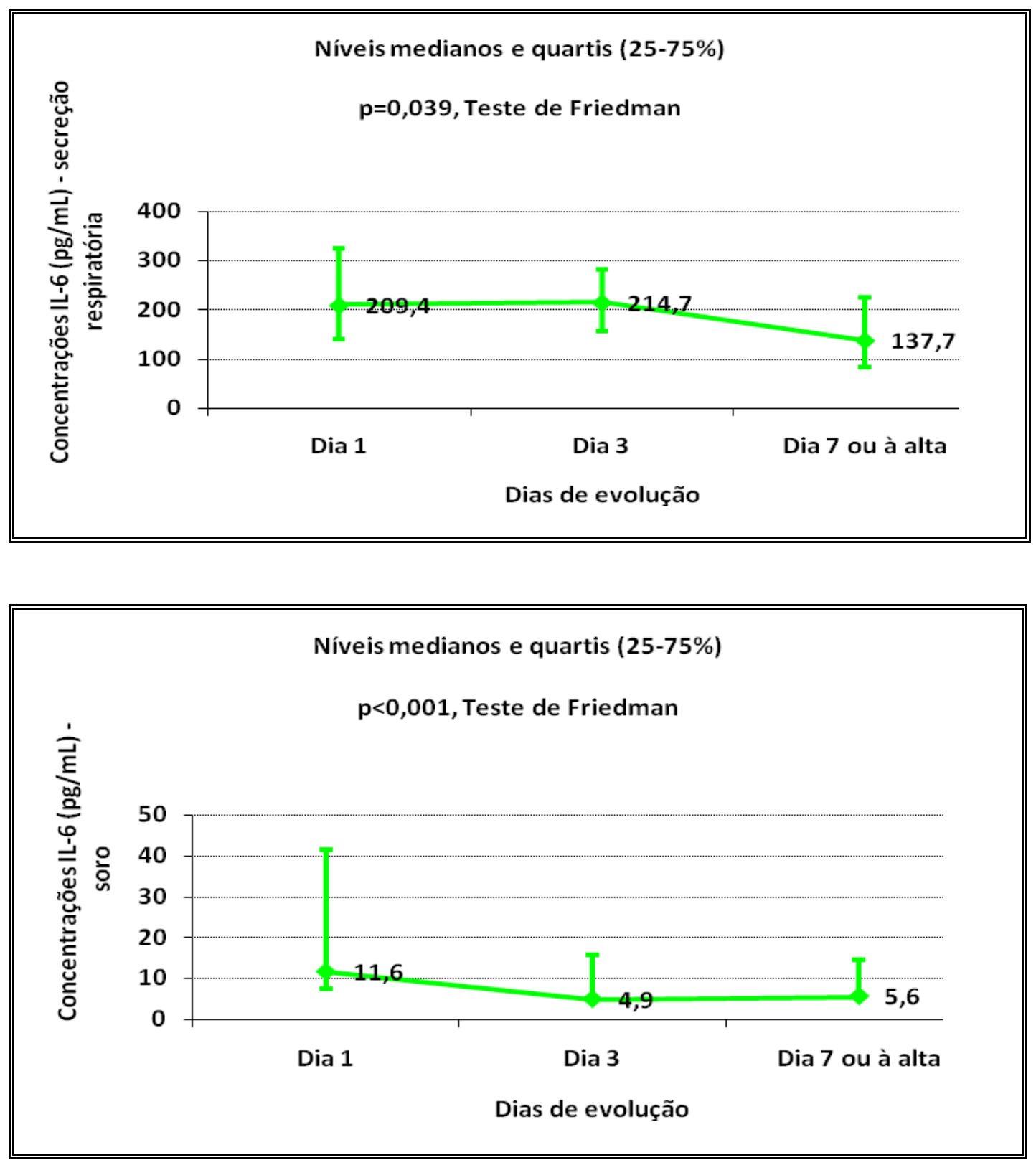

Constatou-se que o efeito do tempo foi significante para IL-6 na secreção nasofaríngea e no soro das crianças com infecção pelo VSR estudadas, indicando que existe variação das suas concentrações durante a evolução da doença (Gráficos 8 e 9). 
GRÁFICOS 10 E 11 - ANÁLISE NÃO PARAMÉTRICA DOS NÍVEIS MEDIANOS DAS CONCENTRAÇÕES DE IL-10 NA SECREÇÃO NASOFARÍNGEA

E NO SORO DE 30 CRIANCCAS COM IDADE INFERIOR A 3 MESES E ITRI PELO VSR: EFEITO DO TEMPO DE EVOLUÇÃO
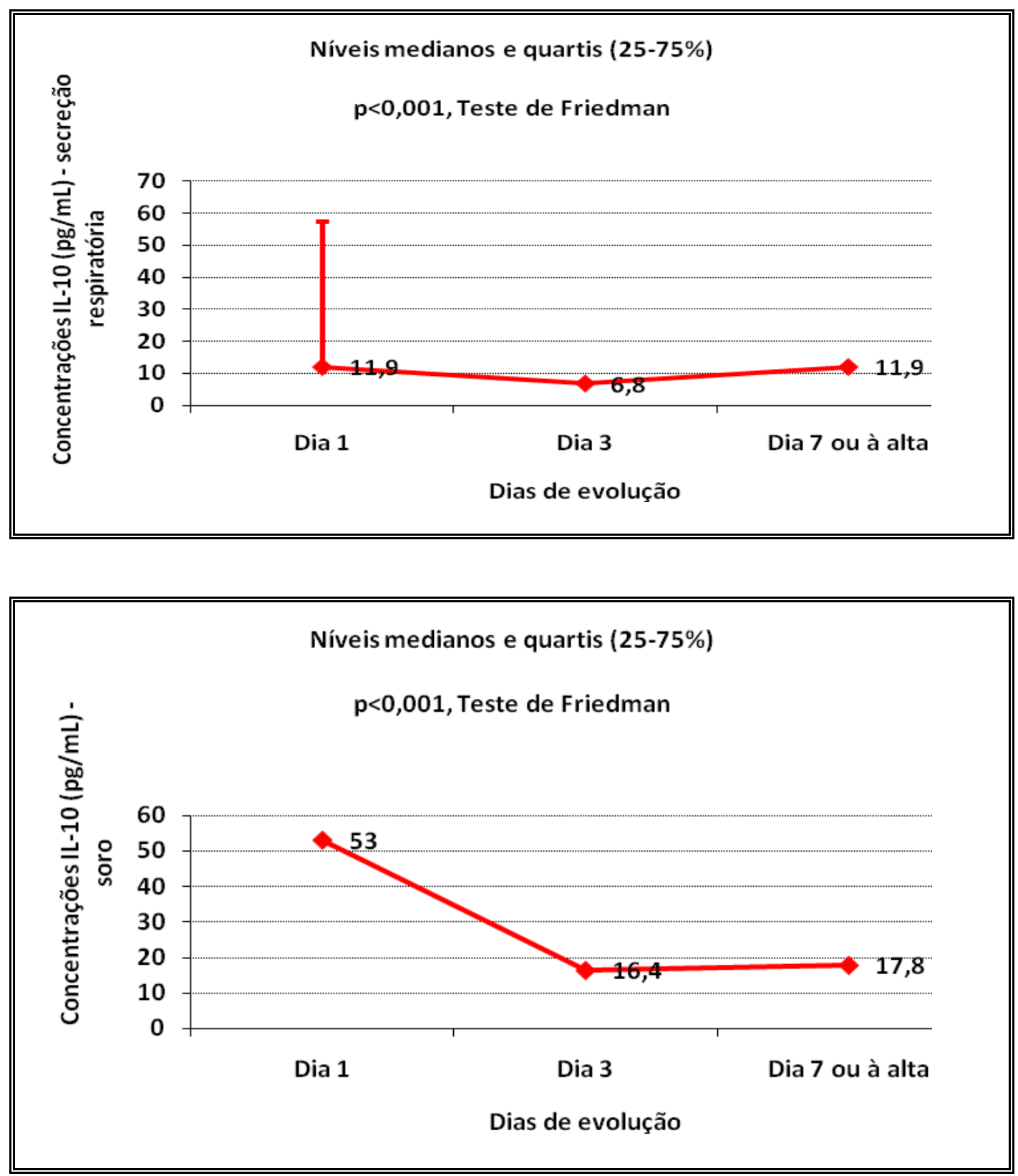

Verificou-se que o efeito do tempo foi significante para IL-10 na secreção nasofaríngea e no soro das crianças com ITRI pelo VSR desta casuística, indicando que existe variação das suas concentrações ao longo dos dias de evolução da doença (Gráficos 10 e 11). 
TABELA 8 - ANÁLISE NÃO PARAMÉTRICA DOS NÍVEIS MEDIANOS DAS CONCENTRAÇÕES DOS MEDIADORES INFLAMATÓRIOS NA SECREÇÃO NASOFARÍNGEA E NO SORO DE 30 CRIANÇAS COM IDADE INFERIOR A 3 MESES E ITRI PELO VSR*: COMPARAÇÕES MÚLTIPLAS

\begin{tabular}{|c|c|}
\hline COMPARAÇÕES MÚLTIPLAS & ANÁLISE NÃO PARAMÉTRICA \\
\hline \multicolumn{2}{|l|}{ RANTES - secreção nasofaríngea } \\
\hline Dia 1 X Dia 3 & $p>0,05$ \\
\hline Dia $1 X$ Dia 7 ou à alta hospitalar & $p<0,01$ \\
\hline Dia 3 X Dia 7 ou à alta hospitalar & $p>0,05$ \\
\hline \multicolumn{2}{|l|}{ sICAM-1 - secreção nasofaríngea } \\
\hline Dia $1 \times$ Dia 3 & $p<0,05$ \\
\hline Dia $1 \times$ Dia 7 ou à alta hospitalar & $p<0,05$ \\
\hline Dia $3 \times$ Dia 7 ou à alta hospitalar & $p>0,05$ \\
\hline \multicolumn{2}{|l|}{ TNF- $\alpha$ - soro } \\
\hline Dia 1 X Dia 3 & $\mathrm{p}<0,001$ \\
\hline Dia $1 X$ Dia 7 ou à alta hospitalar & $p<0,05$ \\
\hline Dia $3 \times$ Dia 7 ou à alta hospitalar & $p<0,01$ \\
\hline \multicolumn{2}{|l|}{ IL-6 - secreção nasofaríngea } \\
\hline Dia $1 \times$ Dia 3 & $p>0,05$ \\
\hline Dia $1 X$ Dia 7 ou à alta hospitalar & $p<0,05$ \\
\hline Dia 3 X Dia 7 ou à alta hospitalar & $p>0,05$ \\
\hline \multicolumn{2}{|l|}{ IL-6 - soro } \\
\hline Dia $1 \times$ Dia 3 & $\mathrm{p}<0,001$ \\
\hline Dia 1 X Dia 7 ou à alta hospitalar & $p>0,05$ \\
\hline Dia $3 \times$ Dia 7 ou à alta hospitalar & $p>0,05$ \\
\hline \multicolumn{2}{|l|}{ IL-10 - secreção nasofaríngea } \\
\hline Dia $1 \times$ Dia 3 & $p<0,001$ \\
\hline Dia $1 \mathrm{X}$ Dia 7 ou à alta hospitalar & $p>0,05$ \\
\hline Dia $3 \times$ Dia 7 ou à alta hospitalar & $p<0,001$ \\
\hline \multicolumn{2}{|l|}{ IL-10 - soro } \\
\hline Dia $1 \times$ Dia 3 & $p<0,001$ \\
\hline Dia 1 X Dia 7 ou à alta hospitalar & $\mathrm{p}<0,001$ \\
\hline Dia 3 X Dia 7 ou à alta hospitalar & $p>0,05$ \\
\hline
\end{tabular}


Em relação à RANTES e à IL-6 na secreção nasofaríngea dos pacientes com VSR, foram constatadas diferenças estatisticamente significantes entre as concentrações medidas nos dias 1 e 7 ou à alta hospitalar (Tabela 8). As medianas das concentrações de RANTES e IL-6 na secreção nasofaríngea diminuíram entre os dias 1 e 7 ou à alta hospitalar (Gráficos 2 e 8).

No que se refere à sICAM-1 na secreção nasofaríngea e à IL-10 no soro das crianças com infecção pelo VSR desta casuística, houve diferenças significantes entre as concentrações aferidas nos dias 1 e 3 e nos dias 1 e 7 ou à alta hospitalar (Tabela 8). As medianas dos níveis de sICAM-1 na secreção nasofaríngea e de IL-10 no soro declinaram entre os dias 1 e 3 e entre os dias 1 e 7 ou à alta (Gráficos 4 e 11).

$\mathrm{Na}$ análise do TNF- $\alpha$ no soro dos nossos pacientes, encontramos diferenças estatisticamente significantes entre as concentrações medidas nos dias 1 e 3 , nos dias 1 e 7 ou à alta e nos dias 3 e 7 ou à alta hospitalar (Tabela 8). As medianas dos níveis de TNF-a no soro elevaram-se entre os dias 1 e 3 e entre os dias 1 e 7 ou à alta, com declínio entre os dias 3 e 7 ou à alta hospitalar (Gráfico 7).

Quanto à IL-6 no soro dos nossos pacientes com ITRI pelo VSR, identificamos diferenças significantes entre as concentrações medidas nos dias 1 e 3 (Tabela 8). As medianas das concentrações de IL-6 no soro diminuíram entre os dias 1 e 3 e mantiveram-se estáveis até o dia 7 ou à alta (Gráfico 9). 
Em se tratando da IL-10 na secreção nasofaríngea das crianças com infecção pelo VSR, houve diferenças estatisticamente significantes entre as concentrações analisadas nos dias 1 e 3 e nos dias 3 e 7 ou à alta (Tabela 8). Inicialmente, as medianas das concentrações de IL-10 na secreção nasofaríngea apresentaram decréscimos entre os dias 1 e 3 e depois elevaram-se entre os dias 3 e 7 ou à alta hospitalar (Gráfico 10). 


\section{DISCUSSÃO}

As ITRI são responsáveis por índices elevados de morbidade e hospitalização de crianças nos países em desenvolvimento, sendo atribuídas a elas cerca de $90 \%$ das mortes por problemas respiratórios (McCarthy et al., 1999). No Brasil, as taxas de mortalidade infantil por pneumonia variam de acordo com a região, sendo mais altas nos Estados do Norte e Nordeste e mais baixas no Sul. As ITRI correspondem aproximadamente a $12 \%$ dos atendimentos ambulatoriais e a $30 \%$ das internações em pediatria (Paiva et al., 1998).

A bronquiolite e a pneumonia pelo VSR são doenças que possuem prevalência alta na população pediátrica em todos os continentes, com espectro amplo de manifestações clínicas e comprometimento pulmonar de intensidade variável (Anderson et al., 1990; Avendaño et al., 1991; Miyao et al., 1999; Nascimento et al., 1991; Sutmöller et al., 1995; Webber et al., 1998). Estudos da resposta dos mediadores inflamatórios durante a infecção pelo VSR contribuem para o melhor entendimento da patogênese da doença pelo vírus e da resposta imune.

Realizaremos a discussão na ordem da apresentação dos resultados.

\subsection{Características dos pacientes estudados}

Em relação às características das 30 crianças com idade inferior a 3 meses e ITRI pelo VSR do presente estudo, os pacientes com quadro 
respiratório de moderado a grave (14 casos) à admissão hospitalar foram os que apresentaram, de forma estatisticamente significante, necessidade de ventilação mecânica e duração do desconforto respiratório, tempos de oxigenoterapia e de internação mais prolongados (Tabelas 2 e 3).

A maior morbidade das crianças com quadro respiratório de moderado a grave pode ser parcialmente explicada pela ação mais intensa da cascata inflamatória em alguns indivíduos, que pode aumentar o dano causado ao trato respiratório inferior pelo VSR, e pela presença à admissão hospitalar de coinfecção com outros agentes etiológicos, como a Chlamydia trachomatis em um caso e o metapneumovírus humano em outro. Apesar disto, não houve óbitos em nossa casuística, em parte, devido à ausência de fatores de risco específicos para doença grave pelo VSR, como displasia broncopulmonar, cardiopatia congênita e imunodeficiência, e também pela maioria dos nossos pacientes terem nascido a termo.

\subsection{Correlação entre as concentrações dos mediadores inflamatórios nas primeiras, segundas e terceiras amostras de secreção nasofaríngea e soro e os marcadores clínicos de gravidade da ITRI pelo VSR}

A importância das citocinas e quimiocinas na gravidade das ITRI pelo VSR ainda não está completamente elucidada. Pesquisas prévias demonstram que o desbalanço na resposta imune (Legg et al., 2003) e mediadores inflamatórios específicos podem contribuir para a gravidade da doença viral (Garofalo et al., 2001). A produção balanceada de mediadores pró e anti-inflamatórios promove atividade antiviral potente, reduzindo a 
patogênese e a morbimortalidade da doença respiratória pelo VSR. Quanto mais jovem a criança, maior a dificuldade em regular a produção de mediadores pró e anti-inflamatórios (Bennett et al., 2007; McNamara et al., 2004).

Este estudo é o primeiro a avaliar, de modo evolutivo, a presença de correlação entre as concentrações dos mediadores inflamatórios (RANTES, sICAM-1, TNF- $\alpha$, IL-6 e IL-10) na secreção nasofaríngea e no sangue periférico, bem como entre as razões destes mediadores inflamatórios, e os marcadores clínicos de gravidade da ITRI pelo VSR em pacientes com idade inferior a 3 meses. Encontramos as seguintes correlações significantes entre as concentrações dos mediadores inflamatórios e suas razões na secreção nasofaríngea e no soro e os marcadores de gravidade da doença respiratória:

- Os pacientes do nosso estudo com concentrações mais elevadas de sICAM-1 e IL-10 na secreção nasofaríngea e de IL-6 no soro (primeiras amostras) (Tabela 4A), bem como aqueles com razão IL6/TNF- $\alpha$ mais elevada e razões IL-10/IL-6, sICAM-1/IL-6 e RANTES/LL-6 mais baixas nas primeiras amostras de soro, apresentaram maior gravidade do quadro respiratório à admissão na UCINE, de acordo com o sistema de escore clínico modificado de De Boeck et al. (1997).

- As crianças que apresentaram razão RANTES/IL-10 maior nas segundas amostras de secreção nasofaríngea, como também aquelas com razões IL-6/TNF- $\alpha$ e IL-6/IL-10 maiores e razões RANTES/IL-6, 
TNF-a/IL-6 e IL-10/IL-6 menores nas segundas amostras de soro, evoluíram no terceiro dia de internação ainda com quadro respiratório grave, conforme o sistema de escore clínico modificado.

- Os pacientes com concentrações mais elevadas de IL-6 (Tabela 4B), com razão IL-6/TNF- $\alpha$ mais alta e razões IL-10/IL-6 e sICAM-1/IL-6 mais baixas no soro à admissão hospitalar evoluíram com tempo de oxigenoterapia e duração da internação mais prolongados. As crianças com razão RANTES/IL-6 mais baixa nas primeiras amostras de soro também permaneceram mais tempo internadas.

Nossos resultados sugerem que a produção aumentada, local e sistêmica, de certos mediadores pró e anti-inflamatórios (sICAM-1 e IL-10 pelo epitélio respiratório e IL-6 pelas células mononucleares e neutrófilos do sangue periférico) na fase aguda da ITRI pelo VSR contribuiu para a evolução clínica mais grave e prolongada de alguns pacientes. A sICAM-1 e a IL-10 na secreção nasofaríngea e a IL-6 no soro determinados à admissão hospitalar se mostraram marcadores adequados da gravidade da ITRI pelo VSR (Tabela 4A). A IL-6 no soro à admissão foi capaz de predizer quais pacientes evoluiriam com tempo de oxigenoterapia e duração da internação mais prolongados (Tabela 4B). Talvez o tamanho da amostra usado neste estudo tenha limitado a presença de correlações significantes entre os marcadores clínicos de gravidade e as concentrações de RANTES, TNF- $\alpha$ e IL-6 na secreção nasofaríngea e as concentrações de RANTES, sICAM-1, TNF-a e IL-10 no soro. Na análise das razões dos mediadores inflamatórios, constatou-se que IL-10/L-6 (nos soros à admissão hospitalar), e IL-6/TNF- $\alpha$ 
e IL-6/IL-10 (nos soros do terceiro dia de evolução) foram associadas de forma mais significante $(p<0,001)$ à gravidade da ITRI pelo VSR.

Intervenções terapêuticas objetivando modular os níveis destes mediadores imunes poderiam potencialmente melhorar a função pulmonar durante a fase aguda da doença pelo VSR, com redução da produção de muco e da hiper-reatividade das vias aéreas, conforme já descrito por Bermejo-Martin et al. (2007).

Alguns autores também têm demonstrado que a elevação de mediadores pró e anti-inflamatórios no início do quadro infeccioso está associada à maior gravidade da doença pelo VSR (Hornsleth et al., 1998; Hornsleth et al., 2001), enquanto outros pesquisadores relatam que as respostas pró e anti-inflamatória agudas podem estar relacionadas à ITRI menos grave pelo VSR, devido ao efeito protetor destes mediadores nas vias aéreas durante a infecção primária pelo vírus (Bennett et al., 2007; Sheeran et al., 1999).

Hornsleth et al. (1998), em Copenhague (Dinamarca), avaliam crianças de até 48 meses de idade internadas com ITRI pelo VSR. Demonstram que a razão IL-6/TNF- $\alpha$ em amostras de secreção nasofaríngea à admissão hospitalar está associada à gravidade da doença pelo VSR (frequência respiratória acima de 60 incursões/minuto, infiltrado peribrônquico ou alveolar, suporte respiratório e duração da internação superior a 7 dias). No entanto, os autores não conseguem relacionar as concentrações séricas de IL-6 à admissão ou a razão IL-6/TNF- $\alpha$ no soro à gravidade da doença pelo VSR. 
Hornsleth et al. (2001), em Copenhague (Dinamarca), estudando as razões dos mediadores inflamatórios em secreções nasofaríngeas de 28 crianças infectadas pelo VSR, com até 5 meses de idade e sem antecedentes de prematuridade ou de outras doenças, constatam correlações positivas significantes entre a gravidade da doença respiratória (maior necessidade de suporte respiratório e hospitalização prolongada) e as razões TNF-R1/RANTES, IL-8/RANTES e RANTES/IL-10. A razão TNFR1/RANTES é a que apresenta associação mais significante à gravidade da doença pelo VSR.

Sheeran et al. (1999), em Dallas, Texas (EUA), encontram correlações negativas significantes entre as concentrações de IL-8 e RANTES em aspirados traqueais à admissão hospitalar e os marcadores de gravidade da doença pelo VSR (oxigenoterapia, ventilação mecânica e internação prolongadas).

Bennett et al. (2007) avaliando 63 crianças internadas no Texas (EUA) com bronquiolite pelo VSR e idade inferior a 24 meses, notam correlações negativas significantes entre o tempo de oxigenoterapia destes pacientes e os níveis de IL-6, IL-8, IL-10, IFN-ץ e MIP-1 $\beta$ em amostras de lavado nasal. Os autores sugerem neste trabalho que níveis elevados de certos mediadores inflamatórios possam proteger contra a hipóxia na bronquiolite.

Outros estudos não relatam qualquer tipo de associação entre os valores dos mediadores inflamatórios e os marcadores clínicos de gravidade da ITRI pelo VSR (Smyth et al., 1997; Chung e Kim, 2002; Lai et al., 2004). 
Smyth et al. (1997) estudando sICAM-1, IL-4, proteína catiônica eosinofílica e outros mediadores inflamatórios no soro de 94 crianças com infecções respiratórias pelo VSR, não evidenciam qualquer relação entre os mediadores inflamatórios estudados e a gravidade da doença dos pacientes.

Chung e Kim (2002) estudam 30 pacientes, com média de idade de 92 dias e variação de 28 a 228 dias, internados em Taegu (Coréia) com diagnóstico de bronquiolite pelo VSR. Os autores verificam que a RANTES na secreção nasal dos pacientes com sintomas graves $\left(\mathrm{PaO}_{2}\right.$ inicial $<85$ mmHg, necessidade de ventilação mecânica e sibilância persistente por mais de 7 dias) não foi significantemente maior do que naqueles com quadros mais leves.

Lai et al. (2004) analisam 47 crianças, com mediana da idade de 14 meses, portadoras de bronquiolite aguda (18 com VSR positivo e $29 \mathrm{com}$ VSR negativo) internadas em Taipei, Taiwan (China), 25 pacientes à alta hospitalar (12 com VSR positivo e 13 com VSR negativo) e 10 crianças saudáveis, com mediana da idade de 18 meses, como controle. Os autores observam que a melhora no escore clínico de gravidade (frequência respiratória, sibilância, uso de musculatura acessória e cianose) não se correlaciona a mudanças nos níveis séricos de SICAM-1.

\subsection{Grupos de cepas do VSR}

Os dois grupos de cepas do VSR (A e B), antigenicamente distintos, podem cocircular durante a sazonalidade do vírus, com predominância variável a cada ano de um grupo em relação ao outro nas diversas partes do 
mundo (Cintra et al., 2001; Hall et al., 1990; Monto e Ohmit, 1990). Grupos diferentes do VSR podem predominar regionalmente em um mesmo surto anual. Isto pode ocorrer devido aos surtos do VSR não fazerem parte da disseminação sazonal do mesmo em todo o mundo, mas serem disseminações regionais múltiplas do vírus mantido localmente (Gilchrist et al., 1994). Os dois grupos de VSR causaram ITRI nas 30 crianças com idade inferior a 3 meses internadas na UCINE, sendo que o grupo A foi o mais freqüente $(57 \%)$ (Gráfico 1). Nossos resultados estão de acordo com a literatura, que constata que as cepas do grupo A tendem a ser até três vezes mais frequentes do que as do grupo B (Anderson et al., 1991; Moura et al., 2003; Mufson et al., 1988; Vieira, 2004). No entanto, há surtos de VSR descritos por outros autores com incidência similar de ambos os grupos e outros com predomínio do grupo B (Siqueira et al., 1991; Straliotto et al., 2001). Mufson et al. (1988), em West Virgínia nos Estados Unidos da América (EUA), analisando amostras de secreção nasofaríngea positivas para o VSR, de 1981 a 1986, encontram predomínio do grupo A em praticamente todos os anos, exceto em uma epidemia na qual houve maior prevalência do grupo B. Anderson et al. (1991), nos EUA, relatam que os dois grupos do VSR podem coexistir na mesma epidemia e na sua pesquisa os vírus do grupo A são identificados com maior frequência. Imaz et al. (2000), em Santa Fé na Argentina, mostram que o grupo A do VSR predomina em quatro surtos consecutivos no inverno e a atividade do grupo B é observada em três das quatro epidemias estudadas. 
No Brasil, Siqueira et al. (1991), no Rio de Janeiro, e Cintra et al. (2001), em Ribeirão Preto (São Paulo), observam que os grupos A e B do VSR podem circular simultaneamente em um mesmo surto sazonal, com predominância variável dos grupos em diferentes anos. Moura et al. (2003), em Salvador na Bahia, e Vieira (2004), na cidade de São Paulo, identificam que ambos os grupos de cepa do VSR podem causar infecção respiratória aguda, com predomínio do grupo A nas epidemias estudadas.

Estudos entre os grupos do VSR e a gravidade da doença respiratória têm resultados variados em diferentes localidades (Brouard et al., 1993; David et al., 1993; Hall et al., 1990; Kneyber et al., 1996; McConnochie et al., 1990; Walsh et al., 1997). Em nossa casuística, as crianças infectadas pelo grupo B do VSR foram as que evoluíram com maior morbidade durante a internação. Isto não é um achado usual, porém não é completamente incomum. Nossos resultados são semelhantes aos encontrados por Hornsleth et al. (1998), que estudando 85 crianças com ITRI pelo VSR admitidas em um hospital de Copenhague (Dinamarca), durante o inverno de 1993 a 1995, verificam a ocorrência de doença respiratória mais grave nas crianças com até 5 meses de idade e infecção pelas cepas do grupo B (genótipo B1122). Hall et al. (1990) também observam que o grupo B do VSR pode causar epidemias graves.

Alguns investigadores relatam associação entre o grupo A do VSR e doença respiratória mais grave (Imaz et al., 2000; Mufson et al., 1988; Walsh et al., 1997), enquanto outros não encontram associação estatística entre os grupos do VSR e a gravidade da doença respiratória (Cintra et al., 2001; 
Hendry et al., 1986; McIntosh et al., 1993; Monto e Ohmit, 1990; Oliveira et al., 2008; Russi et al., 1989; Salomón et al., 1991; Stark et al., 1991).

Estudos em algumas cidades brasileiras têm mostrado diversidade do padrão sazonal do VSR, provavelmente relacionada à grande variação climática em nosso país. Moura et al. (2003) relatam em seu estudo que o período epidêmico do VSR em Salvador (Bahia), com clima tropical, dura 7 meses, com pico de ocorrência de maio a julho, coincidindo com a estação chuvosa. Mello e Silva (1992) também observam correlação entre o pico de casos pelo VSR e a presença de estação chuvosa em Belém (Pará), que tem clima equatorial. Em nosso estudo, identificamos o VSR com maior frequência no outono. Achado semelhante foi encontrado em outras pesquisas realizadas em São Paulo e no Rio de Janeiro, onde o clima é subtropical. Os surtos de VSR no sudeste do Brasil começam no final de março ou início de abril, têm pico em maio, e persistem por 5 meses (Cintra et al., 2001; Nascimento et al., 1991; Vieira et al., 2001; Vieira, 2002). O pico das infecções pelo VSR em São Paulo e Rio de Janeiro não está associado às estações chuvosas, que duram de janeiro a março e de setembro a novembro, e nem aos meses mais frios (junho, julho e agosto). Os surtos epidêmicos no sul do Brasil mostram padrão temperatura-dependente, com pico em julho ou agosto (os meses mais frios do ano) e não estão associados às chuvas (Straliotto et al., 2001). Este padrão de surtos de VSR é similar ao observado em outros países da América do Sul, tais como o Chile, Uruguai e a Argentina (Avendaño et al., 1991; Imaz et al., 2000; Russi et al., 1989). 


\subsection{Comparação das concentrações dos mediadores inflamatórios na secreção nasofaríngea e no soro}

Níveis de RANTES, sICAM-1, TNF- $\alpha$, IL-6 e IL-10 foram detectados nas três amostras de secreção nasofaríngea e de soro das crianças com ITRI pelo VSR internadas na UCINE, confirmando o papel destes mediadores inflamatórios na patogênese da doença. Na comparação entre as concentrações destes mediadores inflamatórios nas primeiras, segundas e terceiras amostras de secreção nasofaríngea e soro das 30 crianças com infecção pelo VSR, verificamos que as medianas das concentrações de RANTES, SICAM-1 e IL-10 foram significantemente maiores nas três amostras de soro; enquanto as medianas das concentrações de IL-6 predominaram, de modo significante, nas três amostras de secreção nasofaríngea (Tabelas 5A, 5B e 5C). A mediana das concentrações de TNFa foi maior apenas nas primeiras amostras de secreção nasofaríngea, de forma também estatisticamente significante (Tabela 5A).

Nossos resultados foram semelhantes aos encontrados por outros autores (Bermejo-Martin et al., 2007; Jafri et al., 1999) e sugerem que os mediadores pró-inflamatórios RANTES, sICAM-1, TNF- $\alpha$ e IL-6, bem como a citocina regulatória IL-10, exerçam papel fundamental tanto na resposta inflamatória local (epitélio respiratório) como na sistêmica (células brancas do sangue periférico) induzida pelo VSR, apesar da imunidade das mucosas poder ser independente da periférica. Não encontramos em nosso estudo correlações significantes entre as concentrações dos mediadores inflamatórios na secreção nasofaríngea e no soro (primeiras, segundas e 
terceiras amostras) das crianças com ITRI pelo VSR (Tabela 6), o que está de acordo com os achados de Jafri et al. (1999), Pitrez et al. (2004) e Bermejo-Martin et al. (2007).

Jafri et al. (1999) avaliam 18 crianças (10 intubadas e oito não intubadas; idade: mediana de 2 meses) admitidas em um hospital no Texas (EUA) com bronquiolite/pneumonia pelo VSR. Treze crianças sem sinais ou sintomas de infecção respiratória são consideradas como grupo controle. Os autores coletam amostras de sangue e de secreções nasofaríngea e traqueal de todos os pacientes para a análise das concentrações de IL-6, IL8 e RANTES. IL-6, IL-8 e RANTES são detectados nas amostras de soro e de secreções nasofaríngea e traqueal de todas as crianças com infecção pelo VSR. Os pesquisadores não observam qualquer correlação significante entre as concentrações respiratórias e séricas destas citocinas.

Pitrez et al. (2004), em Porto Alegre (Rio Grande do Sul), analisam os níveis de IFN-r, IL-4 e IL-10 em amostras de aspirados nasofaríngeos e de células mononucleares do sangue periférico de 20 crianças internadas com bronquiolite viral aguda associada ao primeiro episódio de sibilância, sendo 17 casos devido ao VSR. Os autores relatam ausência de associação entre os níveis de IFN-ץ e IL-10 nos aspirados de nasofaringe e no sangue periférico, porém verificam correlação significante entre os níveis de IL-4.

Bermejo-Martin et al. (2007), na Espanha, estudam 27 mediadores inflamatórios, entre eles RANTES, TNF- $\alpha$, IL-6 e IL-10, em aspirados nasofaríngeos e no plasma de 22 crianças com idade inferior a 2 anos e ITRI grave pelo VSR. Aspirados nasofaríngeos de 22 crianças com sopro 
cardíaco fisiológico são utilizados como controles. Encontram predomínio dos mediadores da imunidade inata, citocinas Th2 (IL-4, IL-6 e IL-13) e quimiocinas CXC (IL-8), ao nível da mucosa. Não identificam associações entre os valores dos mediadores nos aspirados nasofaríngeos e no soro.

\subsection{Comparação das concentrações dos mediadores inflamatórios na secreção nasofaríngea e soro, de acordo com as cepas dos grupos A e B do VSR}

Este estudo é o primeiro na literatura a comparar as concentrações dos mediadores inflamatórios (RANTES, sICAM-1, TNF- $\alpha$, IL-6 e IL-10) na secreção nasofaríngea e no soro de crianças com idade inferior a 3 meses e ITRI pelo VSR, de acordo com os grupos de cepas A e B do vírus. Houve diferença estatisticamente significante entre os dois grupos do VSR apenas em relação à mediana das concentrações de IL-10 nas primeiras amostras de secreção nasofaríngea, que foi mais elevada nas crianças com infecção pelo grupo B do vírus (Tabela 7).

A maior concentração de IL-10 na secreção nasofaríngea à admissão hospitalar das crianças com ITRI pelo grupo B do VSR poderia explicar, em parte, a evolução mais grave destes pacientes, que apresentaram quadro respiratório de moderado a grave à admissão hospitalar (Tabela 2) e tiveram necessidade de ventilação mecânica, dado o comportamento imunossupressor da IL-10. O aumento na expressão de IL-10 no início do quadro infeccioso pode inibir a replicação do VSR, comprometendo o desenvolvimento de uma resposta imune adequada ao vírus, através da 
menor produção de citocinas pró-inflamatórias precoces (Bartz et al., 2002; Chung et al., 2007; Panuska et al., 1995).

\subsection{Efeito do tempo de evolução da doença pelo VSR nas concentrações dos mediadores inflamatórios na secreção nasofaríngea e no soro e comparações múltiplas entre as concentrações dos mediadores inflamatórios}

Em nosso estudo, as concentrações de RANTES, sICAM-1, IL-6 e IL10 na secreção nasofaríngea (Gráficos 2, 4, 8 e 10) e de TNF- $\alpha$, IL-6 e IL-10 no soro (Gráficos 7, 9 e 11) variaram, de forma significante, durante a evolução da ITRI pelo VSR. Os demais mediadores inflamatórios na secreção nasofaríngea e no soro mantiveram seus níveis estáveis durante o período de estudo (Gráficos 3, 5 e 6).

Em relação às comparações múltiplas demonstradas na Tabela 8 , a RANTES, a sICAM-1 e a IL-6 produzidas pelo epitélio respiratório (Gráficos 2, 4 e 8), e a IL-6 e a IL-10 expressas pelas células mononucleares e neutrófilos do sangue periférico (Gráficos 9 e 11) apresentaram pico nos primeiros 3 dias após o início do quadro respiratório, de acordo com a média do tempo de doença à coleta das primeiras amostras de secreção nasofaríngea e sangue, com decréscimo dos seus níveis durante a evolução da doença, refletindo a melhora clínica dos pacientes. A IL-10 na secreção nasofaríngea também apresentou pico dos seus níveis nos primeiros 3 dias após o início da doença, com queda dos seus valores após a admissão hospitalar e nova elevação dos mesmos do dia 3 ao dia 7 ou à alta (Gráfico 
10), caracterizando a perpetuação da ação anti-inflamatória desta citocina em região de epitélio respiratório (Beishuizen et al., 1999), que pode ter contribuído para a ausência de óbitos nesta casuística. A expressão persistente de certos mediadores inflamatórios na fase de resolução dos sintomas tem a função de mediar ou facilitar a migração de células inflamatórias ao foco infeccioso, a fim de debelá-lo de maneira definitiva (Bermejo-Martin et al., 2007). O pico de TNF-a no soro ocorreu após a admissão na UCINE, no terceiro dia de evolução, com declínio dos seus valores até o sétimo dia de evolução ou à alta hospitalar (Gráfico 7). Concentrações menores de citocinas Th1, como a TNF- $\alpha$, e maiores de citocinas Th2, como a IL-6, são descritas em outros estudos na fase aguda da doença grave pelo VSR (Pinto et al., 2006).

Outros autores também têm constatado variação nas concentrações dos mediadores pró e anti-inflamatórios na secreção respiratória e no soro durante a evolução da doença pelo VSR (Hornsleth et al., 1998; Jafri et al., 1999; Matsuda et al., 1995; McNamara et al., 2004; Sheeran et al., 1999).

Matsuda et al. (1995), estudando os níveis de TNF-a nas secreções nasofaríngeas das crianças com infecção pelo VSR, verificam que o TNF- $\alpha$ apresenta pico nos primeiros 5 dias após o início da doença e queda na fase de convalescência.

Hornsleth et al. (1998) detectam aumento das concentrações séricas de IL-6 e TNF- $\alpha$ nas amostras coletadas de 1 a 2 dias após o início da ITRI pelo VSR. Identificam que as concentrações séricas de TNF-a permanecem 
altas, enquanto as de IL-6 diminuem no decorrer de 3 a 4 semanas após o quadro infeccioso.

Jafri et al. (1999) observam declínio significante nas concentrações de RANTES no soro de seus 18 pacientes com infecção pelo VSR entre os dias 1 e 5 de internação $(p=0,02)$.

Sheeran et al. (1999) estudam prospectivamente, durante a sazonalidade do VSR de 1996 a 1997, 14 crianças intubadas e 14 não intubadas internadas com bronquiolite e/ou apneia secundária à infecção pelo VSR em hospital de Dallas, Texas (EUA). Amostras de lavado nasal e aspirado traqueal são obtidas dos pacientes intubados nos dias 1, 3 e 5 de internação. Amostras de lavado nasal são obtidas dos pacientes não intubados nos dias 1 e 3 de internação. Sete crianças saudáveis submetidas à cirurgia eletiva são consideradas como controles. Todas as amostras são analisadas para concentrações de RANTES, MIP-1a, IL-6, IL-8 e IL-10. Os autores constatam redução significante nas concentrações de RANTES e IL10 em lavado nasal durante a internação $(p=0,007$ e $p=0,003$, respectivamente).

McNamara et al. (2004) avaliam, durante a sazonalidade do VSR em Liverpool (Reino Unido) de 2000 a 2001 e de 2001 a 2002, 47 crianças (24 nascidas a termo e 23 pré-termo) com bronquiolite pelo VSR submetidas à ventilação mecânica. Quatorze dos 23 pacientes pré-termo necessitaram de ventilação mecânica no período neonatal e cinco são portadores de displasia broncopulmonar. Nenhuma criança envolvida no estudo recebeu imunoprofilaxia passiva para o VSR. Participam do grupo controle 10 
crianças com idade inferior a 1 ano intubadas para procedimentos cirúrgicos. Coletam lavado broncoalveolar não broncoscópico dos pacientes, nos dias da intubação e da extubação, para medida do RNAm e das proteínas TNF- $\alpha$ e IL-6, além do receptor solúvel do TNF. Os autores verificam que as crianças pré-termo permanecem em ventilação mecânica por mais tempo do que as a termo e têm declínio das proteínas TNF- $\alpha$ e IL-6 entre os dias da intubação e da extubação, fato não observado nas crianças a termo. Dois pacientes pré-termo falecem durante o episódio de bronquiolite

\subsection{Métodos empregados no estudo}

Utilizamos a reação de IFI para detecção rápida do antígeno viral (sensibilidade entre 80 e $90 \%$ e especificidade maior do que $95 \%$ ) ou o isolamento viral em cultura celular (sensibilidade entre 60 e $90 \%$ e especificidade de $100 \%$, no caso da reação de IFI ser negativa para o VSR (Hall, 1998), para investigar a infecção pelo vírus nos pacientes com ITRI à admissão hospitalar ou por ocasião do diagnóstico durante a internação na UCINE. A associação dos métodos de IFI e isolamento viral para identificação do VSR proporcionou altas sensibilidade e especificidade para o diagnóstico etiológico em nosso estudo. No entanto, se tivéssemos realizado também reação em cadeia da polimerase via transcriptase reversa para pesquisa do VSR, talvez pudéssemos ter identificado outros casos com o vírus, porém esta metodologia ainda não está disponível no Laboratório de Vírus Respiratórios do Instituto Adolfo Lutz de São Paulo, que é o local de referência para a investigação de vírus respiratórios no HCFMUSP. 
Acreditamos que alguns casos com resultado negativo para pequisa viral através da reação de IFI e do isolamento em cultura celular possam ter apresentado infecção por outros vírus respiratórios, como o rinovírus, cuja principal forma de diagnóstico é o método molecular.

Durante a análise dos grupos do VSR não tivemos problemas como danos ao antígeno viral durante a estocagem das amostras de secreção nasofaríngea e presença de novas variantes antigênicas do VSR não sensíveis aos reagentes disponíveis no mercado, conforme relatado por alguns autores (Cintra et al., 2001; Straliotto et al., 2001). O uso nesta pesquisa de anticorpos monoclonais específicos para os grupos do VSR conferiu sensibilidade e especificidade elevadas para detecção dos grupos A e $\mathrm{B}$ do vírus.

$\mathrm{Na}$ infecção pelo VSR, a replicação viral ocorre em todo epitélio respiratório e o processo inflamatório das vias aéreas superiores reflete o das inferiores (Anderson et al., 1990). Sheeran et al. (1999) relatam que não se tem detectado qualquer diferença nos níveis dos mediadores inflamatórios determinados nas secreções das vias aéreas superiores e inferiores. Deste modo, coletamos apenas secreção nasofaríngea das crianças envolvidas no estudo, mesmo naquelas intubadas, a fim de unificar - método de coleta da secreção respiratória e devido ao aspirado nasofaríngeo ter risco baixo de problemas para o paciente durante a sua aquisição, além de ser um procedimento de fácil obtenção de amostras com relevância imunológica para todo o trato respiratório. Optamos por não coletar aspirado traqueal dos pacientes para evitar submeter as crianças não 
intubadas a procedimentos mais invasivos e afastar a possibilidade do tubo endotraqueal interferir nos níveis dos mediadores inflamatórios estudados. Para que não houvesse influência nos aspirados nasofaríngeos da sonda nasogástrica, foi passada sonda orogástrica em todos os pacientes que necessitaram de sondagem.

O conhecimento do envolvimento complexo da RANTES, da sICAM-1, do TNF- $\alpha$, da IL-6 e da IL-10 na resposta inflamatória/imune ao VSR foi responsável pela definição da análise destes mediadores inflamatórios em nosso estudo.

As análises das concentrações dos mediadores inflamatórios na secreção nasofaríngea e no soro foram realizadas em monoplicatas devido à dificuldade de aquisição de amostras, principalmente de sangue, de crianças com idade inferior a 3 meses, e à tentativa de redução do risco de anemia secundária por expoliação e de hipóxia ou traumas por aspirações nasofaríngeas mais prolongadas. A escolha, em nosso estudo, pelo emprego do ensaio imunoenzimático ELISA sanduíche da R\&D para medida dos mediadores inflamatórios na secreção nasofaríngea e no soro foi devido à sua sensibilidade da ordem de picogramas $/ \mathrm{mL}$, facilidade de execução e rapidez (de 2 a 3 horas).

Uma proteína controle (uréia ou albumina) não foi medida na secreção nasofaríngea e no soro, como forma de correção do efeito dilucional da amostra de secreção, em vista da literatura mostrar não ocorrer mudanças nos resultados obtidos antes e após esta medida na vigência de processos inflamatórios (Malley et al., 1998). Para corrigir qualquer diferença 
dilucional entre as espécimes estudadas, expressamos os resultados também em razões de mediadores inflamatórios. O fato das concentrações de IL-6 no soro e suas razões terem sido associadas à gravidade da ITRI pelo VSR, confirma que fatores dilucionais não foram tão importantes neste estudo.

A gravidade do quadro respiratório foi avaliada através do sistema de escore clínico modificado de De Boeck et al. (1997), dos tempos de oxigenoterapia e de ventilação mecânica e da duração da internação, que são variáveis consagradas na literatura (Chung e Kim, 2002; Giugno et al., 2004; Sheeran et al., 1999).

Para finalizar, acreditamos que este estudo sirva para sugerir que os mediadores pró-inflamatórios sICAM-1 na secreção nasofaríngea e IL-6 no soro e a citocina regulatória IL-10 na secreção nasofaríngea, medidos à admissão hospitalar, constituem-se em bons parâmetros de avaliação da resposta inflamatória/imune na ITRI pelo VSR, podendo ser utilizados como marcadores de gravidade da doença. Estas observações poderiam contribuir para o delineamento de novas estratégias terapêuticas direcionadas à imunomodulação da doença pelo VSR. 
7

CONCLUSÕES 


\section{CONCLUSÕES}

A análise dos resultados obtidos nos permitiu chegar às seguintes conclusões:

- As concentrações de sICAM-1 e IL-10 na secreção nasofaríngea e de IL-6 no soro determinadas à admissão hospitalar poderiam ser usadas como marcadores de gravidade da ITRI pelo VSR, e a IL-6 no soro poderia ser utilizada para predizer tempo de oxigenoterapia e duração da internação prolongados.

- Na análise das razões dos mediadores inflamatórios, constatou-se que IL-10/IL-6 no soro à admissão, e IL-6/TNF- $\alpha$ e IL-6/IL-10 no soro do terceiro dia de evolução foram associadas de forma mais significante $(p<0,001)$ à gravidade da doença respiratória pelo VSR .

- O grupo de VSR mais frequente nas 30 crianças com idade inferior a três meses e ITRI internadas na UCINE foi o A (57\%), porém foram as crianças com o grupo B do vírus que evoluíram com maior morbidade (quadro respiratório de moderado a grave à admissão hospitalar e necessidade de ventilação mecânica).

- Os mediadores pró-inflamatórios RANTES, sICAM-1, TNF-a e IL-6, bem como a citocina regulatória IL-10, exercem papel fundamental tanto na resposta inflamatória local como na sistêmica induzida pelo VSR 
- Houve diferença estatisticamente significante entre os dois grupos do VSR em relação às concentrações de IL-10 na secreção nasofaríngea à admissão hospitalar, que foram mais elevadas nas crianças com ITRI pelo grupo B do vírus.

- As concentrações de RANTES, sICAM-1, IL-6 e IL-10 na secreção nasofaríngea e de TNF- $\alpha$, IL-6 e IL-10 no soro variaram, de forma significante, durante a evolução da ITRI pelo VSR. Os demais mediadores inflamatórios na secreção nasofaríngea e no soro mantiveram seus níveis estáveis durante o período de estudo. 
8

ANEXOS 


\section{ANEXOS}

\section{ANEXO A}

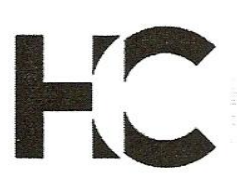

DIRETORIA CLÍNICA

Comissão de Ética para Análise de Projetos de Pesquisa

\section{APROVAÇÃO}

A Comissão de Ética para Análise de Projetos de Pesquisa - CAPPesq da Diretoria Clínica do Hospital das Clínicas e da Faculdade de Medicina da Universidade de São Paulo, em sessão de 24.06.04, APROVOU o Protocolo de Pesquisa $n^{\circ}$ 502/04, intitulado: "Concentração de mediadores inflamatórios em crianças com idade inferior a três meses e infecção do trato respiratório inferior pelo vírus sincicial respiratório" apresentado pelo Departamento de PEDIATRIA, inclusive o Termo de Consentimento Livre e Esclarecido.

Pesquisador(a) Responsável: Profa. Dra. Edna Maria de Albuquerque Diniz

Pesquisador(a) Executante: Dra. Renata Amato Vieira

CAPPesq, 24 de Junho de 2004.

$$
\text { Unthatido }
$$

PROF. DR. EUCLIDES AYRES DE CASTILHO

Presidente da Comissão de Ética para Análise de Projetos de Pesquisa

\footnotetext{
OBSERVAÇÃO: Cabe ao pesquisador elaborar e apresentar à CAPPesq, os relatórios parciais e final sobre a pesquisa (Resolução do Conselho Nacional de Saúde $n^{\circ} 196$, de 10.10.1996, inciso IX.2, letra "c")
} 


\section{ANEXO B \\ HOSPITAL DAS CLÍNICAS \\ DA \\ FACULDADE DE MEDICINA DA UNIVERSIDADE DE SÃO PAULO}

TERMO DE CONSENTIMENTO LIVRE E ESCLARECIDO

I - DADOS DE IDENTIFICAÇÃO DO SUJEITO DA PESQUISA OU RESPONSÁVEL LEGAL

1.NOME DO PACIENTE

DOCUMENTO DE IDENTIDADE № :

SEXO : $M() \quad F()$

DATA NASCIMENTO: ........................

ENDEREÇO

№

APTO:

BAIRRO:

CIDADE

CEP:

TELEFONE: DDD

..)

2.RESPONSÁVEL LEGAL

NATUREZA (grau de parentesco, tutor, curador etc.)

DOCUMENTO DE IDENTIDADE

SEXO: $M() \quad F()$

DATA NASCIMENTO.: ....................

ENDEREÇO:

№

APTO:

BAIRRO:

CEP:

TELEFONE:DDD

CIDADE

\section{II - DADOS SOBRE A PESQUISA CIENTÍFICA}

1. TítULO DO PROTOCOLO DE PESQUISA: Concentrações de mediadores inflamatórios em crianças com idade inferior a três meses e infecção do trato respiratório inferior pelo vírus sincicial respiratório

2. PESQUISADOR RESPONSÁVEL: Profa. Dra. Edna Maria de Albuquerque Diniz CARGO/FUNÇÃO: Médica da Unidade de Cuidados Intensivos Neonatal (UCINE)

INSCRIÇÃO CONSELHO REGIONAL №: 19.327

UNIDADE DO HCFMUSP: UCINE - Instituto da Criança

3. AVALIAÇÃO DO RISCO DA PESQUISA:

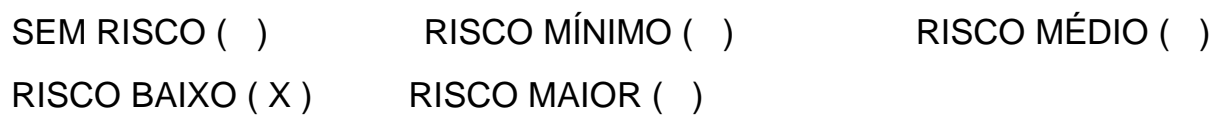

(probabilidade de que o indivíduo sofra algum dano como consequência imediata ou tardia do estudo)

4.DURAÇÃO DA PESQUISA: 18 meses (julho de 2004 a dezembro de 2005) 


\section{III - REGISTRO DAS EXPLICAÇÕES DO PESQUISADOR AO PACIENTE OU SEU REPRESENTANTE LEGAL SOBRE A PESQUISA, CONSIGNANDO:}

1. justificativa e os objetivos da pesquisa: Prezado(a) Senhor(a), como já lhe foi falado seu filho(a) apresenta infecção pulmonar e como estas infecções causadas pelo vírus sincicial respiratório (VSR) são freqüentes e muitas vezes graves na infância, decidimos realizar uma pesquisa para identificar a presença deste vírus e avaliar a reação do organismo da criança à inflamação causada por ele. Nós acompanharemos seu filho(a) durante a internação e neste período serão realizadas coletas de secreção respiratória e sangue, além de radiografias de tórax, para verificar se a doença está melhorando. Estes exames são feitos normalmente em todas as crianças internadas com infecção pulmonar, mesmo que não estejam participando de alguma pesquisa. Se o(a) senhor(a) não quiser que seu filho(a) participe da pesquisa tem todo o direito de se recusar e ele(a) receberá assim mesmo o tratamento mais adequado para a sua doença. Caso comece na pesquisa e depois deseje desistir, também estará garantido para a sua criança o melhor tratamento disponível no hospital.

2. procedimentos que serão utilizados e propósitos: Avaliação clínica (através de exame físico), laboratorial (através da coleta de secreção respiratória e sangue ao diagnóstico de infecção pulmonar) e radiológica (através de radiografias de tórax) dos pacientes. As coletas de secreção respiratória e sangue serão repetidas no terceiro e sétimo dias de evolução ou à alta hospitalar (se antes do sétimo dia) apenas nas crianças com infecção confirmada pelo VSR. O propósito destas coletas repetidas é verificar a regressão da doença. A secreção respiratória será coletada através de sonda plástica, usada uma só vez e jogada fora, durante as aspirações de rotina das narinas ou traquéia, se a criança estiver intubada. O sangue será coletado, em pequena quantidade, de um vaso sangüíneo sob a pele com seringas plásticas e agulhas também usadas uma só vez e jogadas fora. Todos os pacientes terão acompanhamento clínico em nosso ambulatório do Instituto da Criança após a alta hospitalar, estando garantido aos pais ou responsáveis pelas crianças a divulgação dos resultados dos exames ao final do estudo.

3. desconfortos e riscos esperados: Desconforto e risco baixos durante as coletas de secreção respiratória e sangue. Algumas vezes pode ocorrer cianose (coloração arroxeada) e queda dos batimentos cardíacos durante as aspirações de secreção respiratória, que são na maioria dos casos rapidamente revertidas com oxigênio em maior quantidade. No local da picada da agulha para a coleta de sangue poderá se formar uma pequena mancha roxa, que desaparecerá sozinha em poucos dias. Lembrar que em todas as crianças internadas com infecção pulmonar são realizados aspirações de secreção respiratória e exames rotineiros para melhor acompanhamento.

4. benefícios que poderão ser obtidos: Certamente a adesão ao estudo vai proporcionar melhor conhecimento das infecções pelo VSR e poderá auxiliar no desenvolvimento de novos medicamentos para a doença causada por este vírus.

5. procedimentos alternativos que possam ser vantajosos para o indivíduo: Nenhum. 


\section{IV - ESCLARECIMENTOS DADOS PELO PESQUISADOR SOBRE GARANTIAS DO SUJEITO DA PESQUISA:}

1. acesso, a qualquer tempo, às informações sobre procedimentos, riscos e benefícios relacionados à pesquisa, inclusive para dirimir eventuais dúvidas. - SIM

2. liberdade de retirar seu consentimento a qualquer momento e de deixar de participar do estudo, sem que isto traga prejuízo à continuidade da assistência. - SIM

3. salvaguarda da confidencialidade, sigilo e privacidade. - SIM

4. disponibilidade de assistência no HCFMUSP, por eventuais danos à saúde, decorrentes da pesquisa. - SIM

5. viabilidade de indenização por eventuais danos à saúde decorrentes da pesquisa. NÃO

6. divulgação dos resultados dos exames aos pais ou responsáveis pelas crianças ao final do

estudo. - SIM

V. INFORMAÇÕES DE NOMES, ENDEREÇOS E TELEFONES DOS RESPONSÁVEIS PELO ACOMPANHAMENTO DA PESQUISA, PARA CONTATO EM CASO DE INTERCORRÊNCIAS CLÍNICAS E REAÇÕES ADVERSAS:

Profa. Edna Maria de Albuquerque Diniz

Telefone: (011) 8316-5551 (celular)

Dra. Renata Amato Vieira

Telefone: (011) 9986-4730 (celular)

UCINE - Instituto da Criança - HCFMUSP

Av. Dr. Enéas de Carvalho Aguiar, 647 - CEP: 05403-900 - São Paulo - S.P.

Telefone: (011) 3069-8590

\section{OBSERVAÇÕES COMPLEMENTARES:}

\section{VII - CONSENTIMENTO PÓS-ESCLARECIDO:}

Declaro que, após convenientemente esclarecido pelo pesquisador e ter entendido o que me foi explicado, consinto em participar do presente Protocolo de Pesquisa

São Paulo, de de 2 


\section{ANEXO C - NOME (INICIAIS), REGISTRO (RG), TIPO DE DOENÇA \\ RESPIRATÓRIA, SEXO, IDADE GESTACIONAL (IG), PESO DE \\ NASCIMENTO (PN), PESO À ADMISSÃO NA UCINE, IDADE DE \\ INÍCIO DOS SINTOMAS RESPIRATÓRIOS E IDADE À ADMISSÃO \\ DAS 30 CRIANÇAS COM IDADE INFERIOR A 3 MESES E ITRI \\ PELO VSR INCLUÍDAS NO ESTUDO}

\begin{tabular}{|c|c|c|c|c|c|c|c|c|c|c|}
\hline $\begin{array}{l}\text { D } \\
\text { क } \\
0\end{array}$ & NOME & $\mathrm{RG} / \mathrm{HC}$ & $\begin{array}{l}\text { BRON- } \\
\text { QUIOLITE }\end{array}$ & $\begin{array}{l}\text { PNEU- } \\
\text { MONIA }\end{array}$ & $\begin{array}{l}\text { 茴 } \\
\text { X }\end{array}$ & $\begin{array}{c}\text { IG } \\
(\mathrm{sem})\end{array}$ & e & 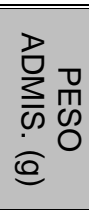 & $\begin{array}{c}\text { ID. } \\
\text { INÍCIO } \\
\text { SINTO- } \\
\text { MAS } \\
\text { (dias) }\end{array}$ & 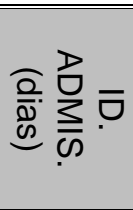 \\
\hline 1 & $\begin{array}{l}\text { A.G.R.L. } \\
\text { S. }\end{array}$ & 6111995I & Sim & Sim & Fem. & 40 & 2960 & 3770 & 17 & 18 \\
\hline 2 & $\begin{array}{l}\text { RN de } \\
\text { A.M.M. }\end{array}$ & $\begin{array}{c}13712365 \\
H\end{array}$ & & Sim & Masc. & 33 & 1495 & 2600 & 46 & 47 \\
\hline 3 & $\begin{array}{l}\text { A.V.G.G. } \\
\text { S. }\end{array}$ & $6113956 \mathrm{~J}$ & Sim & Sim & Fem. & 36 & 2720 & 2620 & 26 & 31 \\
\hline 4 & A.P.S. & $6117752 B$ & Sim & Não & Masc. & 34 & 2010 & 2000 & 22 & 23 \\
\hline 5 & D.C.P. & $6111731 \mathrm{~F}$ & Sim & Não & Masc. & 38 & 2800 & 3460 & 20 & 23 \\
\hline 6 & E.A.S. & $\begin{array}{c}6121938 \\
G\end{array}$ & Sim & Não & Fem. & 39 & 3700 & 3885 & 17 & 22 \\
\hline 7 & $\begin{array}{l}\text { RN de } \\
\text { F.P. }\end{array}$ & $\begin{array}{c}18773587 \\
\mathrm{~J}\end{array}$ & Sim & Sim & Masc. & 39 & 3130 & 4100 & 28 & 31 \\
\hline 8 & G.A.O.M. & $6111953 \mathrm{~A}$ & Não & Sim & Masc. & 40 & 3650 & 3735 & 13 & 18 \\
\hline 9 & G.B.C. & $\begin{array}{c}13640500 \\
K\end{array}$ & Sim & Sim & Masc. & 40 & 2820 & 4210 & 23 & 28 \\
\hline 10 & G.M.S. & $6120823 B$ & Sim & Sim & Masc. & 37 & 2730 & 4200 & 25 & 28 \\
\hline 11 & H.G.P. & $6112471 \mathrm{~A}$ & Sim & Sim & Masc. & 39 & 2945 & 4105 & 19 & 24 \\
\hline 12 & J.V.A.S. & $\begin{array}{c}6112550 \\
D\end{array}$ & Não & Sim & Masc. & 37,5 & 2190 & 3350 & 45 & 50 \\
\hline 13 & K.G.B. & $\begin{array}{c}13633828 \\
1\end{array}$ & Sim & Sim & Masc. & 37,5 & 3450 & 4170 & 27 & 31 \\
\hline 14 & K.V.O.S. & $\begin{array}{c}6114451 \\
H\end{array}$ & Sim & Sim & Masc. & 35 & 2250 & 4100 & 49 & 50 \\
\hline 15 & M.E.D.P. & $\begin{array}{c}13680785 \\
E\end{array}$ & Sim & Sim & Fem. & 37,7 & 3240 & 3235 & 11 & 12 \\
\hline 16 & $\begin{array}{l}\text { M.E.S.S. } \\
\text { M. }\end{array}$ & $\begin{array}{c}6112551 \\
C\end{array}$ & Sim & Sim & Fem. & 38,8 & 3285 & 3890 & 28 & 33 \\
\hline 17 & N.F.R. & $\begin{array}{c}6111983 \\
C\end{array}$ & Sim & Não & Fem. & 36 & 2190 & 2845 & 27 & 30 \\
\hline 18 & P.E.O.F & 6115342 & Sim & Sim & Masc. & 39 & 3010 & 3750 & 29 & 30 \\
\hline 19 & P.Z. & $6105408 \mathrm{~F}$ & Sim & Sim & Masc. & 38 & 3315 & 3780 & 15 & 20 \\
\hline 20 & R.A.L.F. & $\begin{array}{c}6120981 \\
D\end{array}$ & Sim & Não & Masc. & 36 & 2420 & 2700 & 13 & 17 \\
\hline 21 & R.R.S. & $6114481 \mathrm{~J}$ & Sim & Não & Masc. & 38 & 3089 & 3190 & 11 & 12 \\
\hline 22 & R.A.F.S. & $\begin{array}{c}6120327 \\
G\end{array}$ & Sim & Não & Fem. & 33,7 & 1960 & 2655 & 35 & 38 \\
\hline 23 & J.L.S.C. & $\begin{array}{c}13686121 \\
J\end{array}$ & Sim & Sim & Masc. & 39,1 & 3200 & 3280 & 12 & 16 \\
\hline 24 & T.O.S. & $\begin{array}{c}6121948 \\
D\end{array}$ & Sim & Sim & Fem. & 37 & 3900 & 4705 & 32 & 35 \\
\hline 25 & T.F.M.M. & $\begin{array}{c}6112241 \\
G\end{array}$ & Sim & Sim & Fem. & 40 & 2585 & 3465 & 25 & 27 \\
\hline 26 & V.F.S. & $\begin{array}{c}6112532 \\
H\end{array}$ & Sim & Não & Masc. & 40,5 & 3925 & 4550 & 21 & 26 \\
\hline 27 & V.A.N & $6118132 \mathrm{E}$ & Não & Sim & Masc. & 38,3 & 3300 & 3690 & 13 & 18 \\
\hline 28 & V.P.N. & $\begin{array}{c}13674740 \\
H\end{array}$ & Sim & Sim & Masc. & 38,8 & 3190 & 4820 & 33 & 36 \\
\hline 29 & Y.M.B.S. & $\begin{array}{c}13694068 \\
\mathrm{~J}\end{array}$ & Sim & Não & Fem. & 36 & 2450 & 2825 & 19 & 24 \\
\hline 30 & Y.S.S. & $6115427 \mathrm{~F}$ & Sim & Sim & Masc. & 40 & 3185 & 4100 & 27 & 32 \\
\hline
\end{tabular}




\section{ANEXO D - DURAÇÃO DA INTERNAÇÃO, SISTEMA DE ESCORE CLÍNICO MODIFICADO À ADMISSÃO E NOS TERCEIRO E SÉTIMO DIAS DE EVOLUÇÃO OU À ALTA HOSPITALAR, TEMPOS DE OXIGENOTERAPIA E DE VENTILAÇÃO MECÂNICA, GRUPOS DO VSR, PADRÃO DA RADIOGRAFIA DE TÓRAX E ÓBITO DAS 30 CRIANCCAS COM IDADE INFERIOR A 3 MESES E ITRI PELO VSR INCLUÍDAS NO ESTUDO}

\begin{tabular}{|c|c|c|c|c|c|c|c|c|c|}
\hline 疋 & 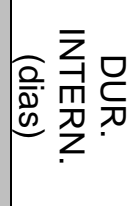 & $\begin{array}{l}\text { ESCORE } \\
\text { CLÍNICO À } \\
\text { ADMISSÃO }\end{array}$ & $\begin{array}{c}\text { ESCORE } \\
\text { CLÍNICO } \\
\text { D3 DE } \\
\text { EVOLUÇÃO }\end{array}$ & $\begin{array}{c}\text { ESCORE } \\
\text { CLÍ́NICO } \\
\text { D7 DE } \\
\text { EVOLUÇÃO } \\
\text { OU Á ALTA }\end{array}$ & 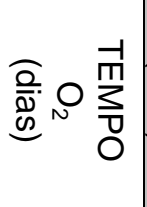 & 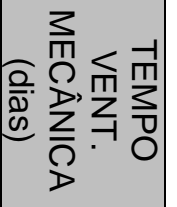 & $\begin{array}{l}\widehat{\omega} \\
\text { D }\end{array}$ & 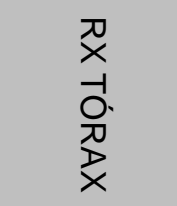 & $\frac{\stackrel{0}{\varpi}}{\frac{\text { }}{二}}$ \\
\hline 1 & 11 & 5 & 4 & 1 & - & - & Grupo A & Intersticial & Não \\
\hline 2 & 10 & 11 & 8 & 6 & 4 & 3 & Grupo B & Misto & Não \\
\hline 3 & 7 & 2 & 2 & 2 & 1 & - & Grupo A & Intersticial & Não \\
\hline 4 & 10 & 1 & 2 & 2 & 2 & - & Grupo A & Intersticial & Não \\
\hline 5 & 14 & 3 & 3 & 3 & - & - & Grupo A & Intersticial & Não \\
\hline 6 & 18 & 7 & 1 & 4 & 14 & - & Grupo A & Intersticial & Não \\
\hline 7 & 8 & 8 & 6 & 2 & 3 & - & Grupo A & Intersticial & Não \\
\hline 8 & 17 & 10 & 11 & 10 & 14 & 12 & Grupo B & Intersticial & Não \\
\hline 9 & 5 & 3 & 3 & 2 & - & - & Grupo A & Intersticial & Não \\
\hline 10 & 8 & 6 & 6 & 4 & 5 & - & Grupo A & Intersticial & Não \\
\hline 11 & 7 & 4 & 5 & 1 & 5 & - & Grupo A & Intersticial & Não \\
\hline 12 & 9 & 6 & 5 & 5 & 7 & - & $\begin{array}{c}\text { Grupos A } \\
\text { e B }\end{array}$ & Intersticial & Não \\
\hline 13 & 9 & 12 & 7 & 3 & 8 & 3 & Grupo B & Intersticial & Não \\
\hline 14 & 27 & 11 & 12 & 10 & 18 & 12 & $\begin{array}{c}\text { Grupos A } \\
\text { e B }\end{array}$ & Intersticial & Não \\
\hline 15 & 6 & 4 & 2 & 1 & - & - & Grupo A & Intersticial & Não \\
\hline 16 & 4 & 1 & 1 & 1 & 4 & - & Grupo A & Intersticial & Não \\
\hline 17 & 11 & 2 & 4 & 3 & 9 & - & Grupo A & Intersticial & Não \\
\hline 18 & 4 & 2 & 3 & 3 & 2 & - & Grupo A & Misto & Não \\
\hline 19 & 9 & 12 & 9 & 6 & 7 & 5 & Grupo B & Intersticial & Não \\
\hline 20 & 6 & 2 & 5 & 2 & 3 & - & Grupo B & Intersticial & Não \\
\hline 21 & 4 & 3 & 2 & 2 & 1 & - & Grupo A & Intersticial & Não \\
\hline 22 & 14 & 7 & 6 & 2 & 7 & - & Grupo A & Intersticial & Não \\
\hline 23 & 50 & 10 & 11 & 12 & 43 & 32 & $\begin{array}{c}\text { Grupos A } \\
\text { e B }\end{array}$ & Intersticial & Não \\
\hline 24 & 18 & 11 & 10 & 11 & 16 & 14 & Grupo B & Misto & Não \\
\hline 25 & 14 & 10 & 9 & 5 & 10 & 5 & Grupo B & Intersticial & Não \\
\hline 26 & 8 & 5 & 5 & 3 & 5 & - & Grupo B & Intersticial & Não \\
\hline 27 & 16 & 10 & 7 & 1 & 10 & 3 & Grupo B & Misto & Não \\
\hline 28 & 14 & 3 & 4 & 1 & 11 & - & Grupo A & Intersticial & Não \\
\hline 29 & 8 & 9 & 3 & 2 & 2 & - & Grupo A & Intersticial & Não \\
\hline 30 & 12 & 12 & 11 & 8 & 11 & 8 & Grupo B & Misto & Não \\
\hline
\end{tabular}




\section{ANEXO E - CONCENTRAÇÕES DE RANTES E SICAM-1 NAS PRIMEIRAS, SEGUNDAS E TERCEIRAS AMOSTRAS DE SECREÇÃO NASOFARÍNGEA E DE SORO DAS 30 CRIANÇAS COM IDADE INFERIOR A 3 MESES E ITRI PELO VSR INCLUÍDAS NO ESTUDO}

\begin{tabular}{|c|c|c|c|c|c|c|c|c|c|c|c|c|}
\hline ๑ & 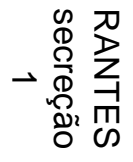 & 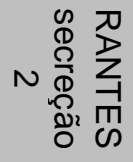 & 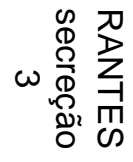 & 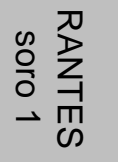 & 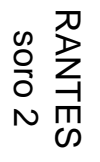 & 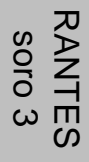 & 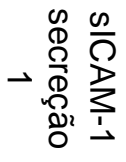 & 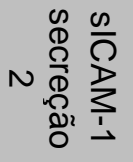 & 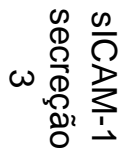 & 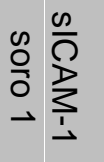 & 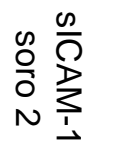 & 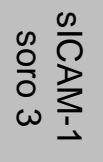 \\
\hline 1 & 984,5 & 23,18 & 58,4 & 971,2 & 555 & 953 & 1436 & 572,6 & 771,7 & 1583 & 1477 & 1548 \\
\hline 2 & 511,7 & 139,1 & 177 & 981,7 & 718 & 931 & 1450 & 787,9 & 1337 & 1692 & 1723 & 1735 \\
\hline 3 & 103 & 16,85 & 32,3 & 897,3 & 907 & 919 & 688 & 339 & 444,6 & 1550 & 1502 & 1445 \\
\hline 4 & 61,39 & 115,7 & 12,4 & 619,2 & 960 & 940 & 885 & 375 & 732,1 & 1733 & 1479 & 1591 \\
\hline 5 & 130,7 & 148,7 & 815 & 664,3 & 861 & 966 & 971 & 1080 & 213 & 1644 & 1711 & 1607 \\
\hline 6 & 118,3 & 44 & 92,9 & 856,5 & 861 & 966 & 1188 & 534 & 546,2 & 1526 & 1481 & 1733 \\
\hline 7 & 173,8 & 203,4 & 493 & 917,7 & 964 & 625 & 1493 & 1160 & 1298 & 1498 & 1690 & 1433 \\
\hline 8 & 86,49 & 46,28 & 12,4 & 882,7 & 896 & 928 & 1080 & 1198 & 1869 & 1552 & 1540 & 1528 \\
\hline 9 & 347,2 & 555,9 & 406 & 888,6 & 526 & 919 & 946 & 1119 & 1160 & 1340 & 1542 & 1634 \\
\hline 10 & 352,5 & 481,7 & 151 & 846,3 & 533 & 910 & 1056 & 1101 & 1052 & 1631 & 1467 & 1536 \\
\hline 11 & 31,57 & 14,57 & 29,6 & 836,1 & 848 & 626 & 457 & 261,4 & 197,8 & 1613 & 1451 & 1488 \\
\hline 12 & 84,62 & 151,7 & 165 & 486,7 & 774 & 912 & 629 & 911,9 & 361,3 & 1514 & 1228 & 1711 \\
\hline 13 & 542,4 & 156,9 & 55,7 & 611,9 & 807 & 811 & 910 & 274 & 133,8 & 1640 & 1558 & 1668 \\
\hline 14 & 280,2 & 202,3 & 18,1 & 677,4 & 906 & 479 & 737 & 308,5 & 131,9 & 1631 & 1271 & 1441 \\
\hline 15 & 227,7 & 35,43 & 32,9 & 849,3 & 839 & 542 & 278 & 131,7 & 540,1 & 1613 & 1686 & 1348 \\
\hline 16 & 657,8 & 77,31 & 42,4 & 793,9 & 868 & 878 & 256 & 434,4 & 156,6 & 1658 & 1686 & $\overline{1348}$ \\
\hline 17 & 84,57 & 23,86 & 12,4 & 876,9 & 449 & 865 & 526 & 204,9 & 202,3 & 1558 & 1364 & 1435 \\
\hline 18 & 324,8 & 254,3 & 178 & 868,2 & 557 & 775 & 506 & 489,3 & 214,5 & 1583 & 1415 & 1459 \\
\hline 19 & 845,9 & 601,6 & 361 & 836,1 & 792 & 902 & 812 & 790 & 934 & 1603 & 1560 & 1629 \\
\hline 20 & 198,1 & 199,3 & 223 & 462 & 900 & 891 & 538 & 615,3 & 828,6 & 1421 & 1419 & 1380 \\
\hline 21 & 33,57 & 126,6 & 35,3 & 577 & 816 & 785 & 530 & 401,9 & 460,3 & 1508 & 1532 & 1542 \\
\hline 22 & 254 & 51,86 & 20,6 & 885,7 & 874 & 500 & 504 & 72,82 & 105,3 & 1325 & 1376 & 1585 \\
\hline 23 & 105,6 & 47,14 & 279 & 872,5 & 984 & 608 & 632 & 662 & 245,5 & 1451 & 1587 & 1175 \\
\hline 24 & 590,4 & 333,4 & 221 & 824,5 & 951 & 878 & 1024 & 883,4 & 1013 & 1563 & 1554 & 1404 \\
\hline 25 & 1050 & 387 & 423 & 826 & 466 & 925 & 652 & 680,3 & 105,3 & 1516 & 1581 & 1662 \\
\hline 26 & 283,6 & 102,3 & 64,4 & 844,9 & 494 & 728 & 536 & 770,2 & 697,5 & 1530 & 1264 & 1520 \\
\hline 27 & 148,7 & 76,28 & 61,7 & 870,1 & 785 & 774 & 284 & 101,3 & 534,6 & 1607 & 1636 & 1544 \\
\hline 28 & 837 & 941,8 & 39,1 & 840,5 & 809 & 798 & 1085 & 952,5 & 1062 & 1589 & 1492 & 1605 \\
\hline 29 & 57,28 & 90 & 48,6 & 795,4 & 790 & 829 & 967 & 1119 & 176,9 & 1692 & 1619 & 1453 \\
\hline 30 & 751,5 & 593,4 & 571 & 824,5 & 864 & 857 & 2352 & 581,2 & 1503 & 1404 & 1498 & 1636 \\
\hline
\end{tabular}




\section{ANEXO F - CONCENTRAÇÕES DE IL-6 E IL-10 NAS PRIMEIRAS, SEGUNDAS E TERCEIRAS AMOSTRAS DE SECREÇÃO NASOFARÍNGEA E DE SORO DAS 30 CRIANÇAS COM IDADE INFERIOR A 3 MESES E ITRI PELO VSR INCLUÍDAS NO ESTUDO}

\begin{tabular}{|c|c|c|c|c|c|c|c|c|c|c|c|c|}
\hline D & 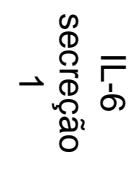 & 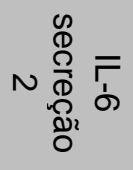 & 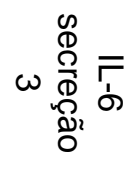 & 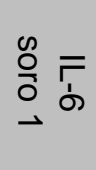 & 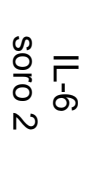 & $\begin{array}{ll}0 & = \\
0 & \overline{0} \\
0 & \overline{1} \\
\omega & \infty\end{array}$ & 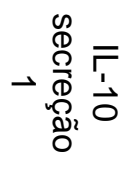 & 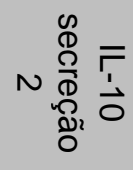 & 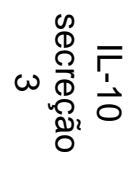 & 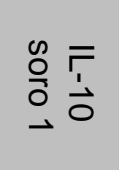 & 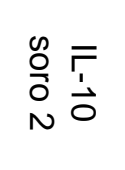 & 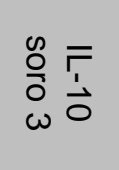 \\
\hline 1 & 171,22 & 264,4 & 116 & 724 & 4,9 & 5,57 & 11,93 & 6,82 & 1,93 & 94,8 & 58,26 & 35,48 \\
\hline 2 & 342,67 & 134,6 & 262 & 200 & 32 & 5,57 & 850,27 & 6,82 & 92,04 & 52,96 & 16,41 & 17,78 \\
\hline 3 & 82,7 & 69,78 & 82 & 7,5 & 4,9 & 5,57 & 11,93 & 6,82 & 1,93 & 52,96 & 16,41 & 17,78 \\
\hline 4 & 140,36 & 85,98 & 82 & 11 & 8,8 & 5,57 & 11,93 & 6,82 & 1,93 & 52,96 & 16,41 & 17,78 \\
\hline 5 & 452,6 & 297,5 & 131 & 86 & 8,5 & 7,5 & 11,93 & 19,32 & 11,93 & 258,57 & 227,97 & 167,57 \\
\hline 6 & 412,49 & 319,1 & 222 & 47 & 5,8 & 14,9 & 96,59 & 6,82 & 11,93 & 52,96 & 16,41 & 17,78 \\
\hline 7 & 199 & 368 & 410 & 7,5 & 4,9 & 5,57 & 16,48 & 6,82 & 41,48 & 52,96 & 16,41 & 17,78 \\
\hline 8 & 196,87 & 209,2 & 229 & 7,5 & 97 & 5,57 & 15,9 & 6,82 & 11,93 & 52,96 & 16,41 & 17,78 \\
\hline 9 & 323 & 620,4 & 338 & 7,5 & 4,9 & 5,57 & 56,25 & 64,2 & 9,2 & 52,96 & 16,41 & 17,78 \\
\hline 10 & 3,74 & 220,2 & 30 & 7,5 & 4,9 & 5,57 & 197,15 & 9,09 & 1,93 & 52,96 & 16,41 & 17,78 \\
\hline 11 & 34,38 & .9 & 5,6 & 7,5 & 4,9 & 5,57 & 11,93 &, 82 & 1,93 & 52,96 & 16,41 & 17,78 \\
\hline 12 & 03,43 & 177,4 & 141 & 53 & 6,8 & 5,57 & 11,93 & 6,82 & 11,93 & 52,96 & 16,41 & 17,78 \\
\hline 13 & 064,7 & 179,5 & 250 & 15 & 4,9 & 5,57 & 40,9 & 6,82 & 11,93 & 52,96 & 16,41 & 17,78 \\
\hline 14 & 271,32 & 230,4 & 69,2 & 37 & 25 & 8,51 & 30,11 & 6,82 & 11,93 & 52,96 & 16,41 & 17,78 \\
\hline 15 & 56,08 & 198,4 & 136 & 7,5 & 4,9 & 5,57 & 11,93 & 6,82 & 11,93 & 52,96 & 16,41 & 17,78 \\
\hline 16 & 211,14 & 169,6 & - & 7,5 & 4,9 & 290 & 1 & 6,82 & 93 & 52,96 & 16,41 & 17,78 \\
\hline 17 & 237,37 & 233,9 & 16,5 & 7,5 & 4,9 & 5,57 & 11,93 & 6,82 & 1,93 & 52,96 & 16,41 & 17,78 \\
\hline 18 & 146,73 & 236,2 & 119 & 12 & 4,9 & 112 & 93 & 6,82 & 11,93 & 52,96 & 16,41 & 17,78 \\
\hline 19 & 628,88 & 206,7 & 131 & 19 & 4,9 & 5,57 & 125,57 & 8,52 & 11,93 & 52,96 & 16,41 & 17,78 \\
\hline 20 & 331,1 & 281 & 225 & 7,5 & 4,9 & 14,2 & 84,66 & 16,48 & 27,27 & 52,96 & 16,41 & 17,78 \\
\hline 21 & 87,9 & 242 & 190 & 11 & 15 & 16,3 & 11,93 & 6,82 & 11,93 & 58,85 & 45,97 & 17,78 \\
\hline 22 & 73,25 & 163,5 & 172 & 19 & 4,9 & 328 & 11,93 & 6,82 & 11,93 & 52,96 & 16,41 & 17,78 \\
\hline 23 & 257,43 & 288,7 & 140 & 153 & 46 & 12,2 & 11,93 & 10,22 & 9,77 & 52,96 & 16,41 & 17,78 \\
\hline 24 & 243,16 & 257 & 10 & 13 & 52 & 401 & 141,48 & 8,52 & 11,93 & 52,96 & 16,41 & 17,78 \\
\hline 25 & 206,13 & 79,03 & 5,82 & 79 & 4,9 & 12,4 & 60,79 & 6,82 & 11,93 & 160,32 & 105,4 & 93,75 \\
\hline 26 & 207,67 & 95,81 & 312 & 7,5 & 4,9 & 213 & 11,93 & 6,82 & 11,93 & 52,96 & 63,03 & 17,78 \\
\hline 27 & 245,86 & 281,3 & 110 & 40 & 4,9 & 5,57 & 11,93 & 6,82 & 11,93 & 52,96 & 16,41 & 17,78 \\
\hline 28 & 73,63 & 203 & 89,1 & 7,5 & 17 & 5,57 & 32,95 & 6,82 & 11,93 & 52,96 & 16,41 & 17,78 \\
\hline 29 & 464,56 & 321,1 & 42,9 & 7,5 & 4,9 & 10,8 & 11 & 6,82 & 11,93 & 52,96 & 215,36 & 56,67 \\
\hline 30 & 30,52 & 31,9 & 100 & 30 & 100 & 5,57 & 11,93 & 6,82 & 11,93 & 52,96 & 16,41 & 17,78 \\
\hline
\end{tabular}




\section{ANEXO G - CONCENTRAÇÕES DE TNF- $\alpha$ NAS PRIMEIRAS, SEGUNDAS E TERCEIRAS AMOSTRAS DE SECREÇÃO NASOFARÍNGEA E DE SORO DAS 30 CRIANCCAS COM IDADE INFERIOR A 3 MESES E ITRI PELO VSR INCLUÍDAS NO ESTUDO}

\begin{tabular}{|c|c|c|c|c|c|c|}
\hline 胥 & 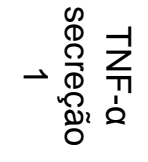 & 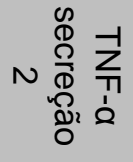 & 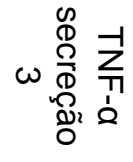 & 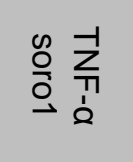 & 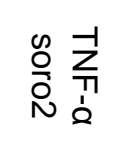 & 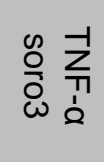 \\
\hline 1 & 12,48 & 10,92 & 13,52 & 39,22 & 22,73 & 20,05 \\
\hline 2 & 2031,38 & 432,71 & 301,77 & 4,4 & 22,73 & 20,05 \\
\hline 3 & 301,77 & 57,17 & 39,52 & 4,4 & 22,73 & 20,05 \\
\hline 4 & 12,48 & 31,72 & 13,52 & 4,4 & 22,73 & 20,05 \\
\hline 5 & 283,4 & 10,92 & 13,52 & 127,47 & 100,28 & 97,16 \\
\hline 6 & 596,7 & 184,08 & 76,96 & 4,4 & 22,73 & 20,05 \\
\hline 7 & 20,8 & 10,92 & 84,76 & 4,4 & 22,73 & 20,05 \\
\hline 8 & 32,76 & 22,36 & 31,72 & 4,4 & 22,73 & 20,05 \\
\hline 9 & 216,84 & 87,36 & 42,12 & 4,4 & 22,73 & 20,05 \\
\hline 10 & 108,16 & 61,36 & 101,92 & 4,4 & 22,73 & 20,05 \\
\hline 11 & 12,48 & 10,92 & 13,52 & 4,4 & 22,73 & 20,05 \\
\hline 12 & 169 & 38,54 & 13,52 & 4,4 & 22,73 & 20,05 \\
\hline 13 & 20,8 & 10,92 & 13,52 & 4,4 & 22,73 & 20,05 \\
\hline 14 & 50,05 & 26,52 & 13,52 & 4,4 & 22,73 & 20,05 \\
\hline 15 & 12,48 & 10,92 & 13,52 & 4,4 & 22,73 & 20,05 \\
\hline 16 & 12,48 & 10,92 & 13,52 & 4,4 & 22,73 & 20,05 \\
\hline 17 & 20,28 & 10,92 & 13,52 & 4,4 & 22,73 & 20,05 \\
\hline 18 & 447,36 & 130,52 & 61,88 & 4,4 & 22,73 & 20,05 \\
\hline 19 & 12,48 & 10,92 & 13,52 & 4,4 & 22,73 & 20,05 \\
\hline 20 & 179,92 & 211,12 & 87,36 & 4,4 & 22,73 & 20,05 \\
\hline 21 & 12,48 & 39 & 13,52 & 78,89 & 73,74 & 78,26 \\
\hline 22 & 22,36 & 10,92 & 13,52 & 4,4 & 22,73 & 20,05 \\
\hline 23 & 317,72 & 754,79 & 326,14 & 4,4 & 22,73 & 20,05 \\
\hline 24 & 409,24 & 62,4 & 13,52 & 4,4 & 22,73 & 20,05 \\
\hline 25 & 139,88 & 10,92 & 13,52 & 40,07 & 36,3 & 38,65 \\
\hline 26 & 97,24 & 101,22 & 161,2 & 4,4 & 22,73 & 20,05 \\
\hline 27 & 249,6 & 135,2 & 13,52 & 4,4 & 22,73 & 20,05 \\
\hline 28 & 14,04 & 20,28 & 13,52 & 4,4 & 22,73 & 20,05 \\
\hline 29 & 31,2 & 88,4 & 42,12 & 4,4 & 22,73 & 20,05 \\
\hline 30 & 12,48 & 50,96 & 76,96 & 4,4 & 22,73 & 20,05 \\
\hline
\end{tabular}




\section{REFERÊNCIAS}

Abbas AK, Lichtman AH. Cytokines. In: Abbas AK, Lichtman AH, editors. Cellular and molecular immunology. 5th ed. Philadelphia: Saunders; 2005. p.243-74.

Abu-Harb M, Bell F, Finn A, Rao WH, Nixon L, Shale d, Everard ML. IL-8 and neutrophil elastase levels in the respiratory tract of infants with RSV bronchiolitis. Eur Respir J. 1999;14:139-43.

Akira S, Takeda K, Kaisho T. Toll-like receptors: critical proteins linking innate and acquired immunity. Nat Immunol. 2001;2:675-80.

Anderson LJ, Hendry RM, Pierik LT, Tsou c, Mclntosh K. Multicenter study of strains of respiratory syncytial virus. J Infect Dis. 1991;163;687-92.

Anderson LJ, Parker RA, Strikas RL. Association between respiratory syncytial virus outbreaks and lower respiratory deaths of infants and young children. J Infect Dis. 1990;161:640-6.

Armitage P, Berry G. Statistical methods in medical research. 3rd ed. Oxford: Blackwell Science; 1994. 
Arruda Neto E, Cintra OAL, Hayden FG. Respiratory virus infections. In: Guerrant RL, Walker DH, Weller PF, editors. Tropical infectious diseases: principles and practice. 2nd ed. Philadelphia: Elsevier Churchill Livingstone; 2006. p.637-59.

Arvin AM, Maldonado YA. Other viral infections of the fetus and newborn. In: Remington J, Klein JO, editors. Infectious diseases of the fetus and newborn infant. 5th ed. Philadelphia: Saunders; 2001. p.855-66.

Avadhanula V, Rodriguez CA, Devincenzo JP, Wang Y, Webby RJ, Ulett GC, Adderson EE. Respiratory viruses augment the adhesion of bacterial pathogens to respiratory epithelium in a viral species- and cell typedependent manner. J Virol. 2006;80:1629-36.

Avendaño LF, Larrañaga C, Palomino MA, Gaggero A, Montaldo G, Suárez M, Diaz A. Community and hospital-acquired respiratory syncytial virus infections in Chile. Pediatr Infect Dis J. 1991;10:564-8.

Bartz H, Büning-Pfaue F, Türkel Ö, Schauer U. Respiratory syncytial virus induces prostaglandin $\mathrm{E}_{2}, \mathrm{IL}-10$ and $\mathrm{IL}-11$ generation in antigen presenting cells. Clin Exp Immunol. 2002;129:438-45.

Beishuizen A, Vermes I, Haanen C. Endogenous mediators in sepsis and septic shock. Adv Clin Chem. 1999;33:55-131. 
Bennett BL, Garofalo RP, Cron SG, Hosakote YM, Atmar RL, Macias CG, Piedra PA. Immunopathogenesis of respiratory syncytial virus bronchiolitis. $J$ Infect Dis. 2007;195:1532-40.

Berman S. Epidemiology of acute respiratory infections in children of developing countries. Rev Infect Dis. 1991;13(Suppl. 6):S454-62.

Bermejo-Martin JF, Garcia-Arevalo MC, De Lejarazu RO, Ardura J, Eiros JM, Alonso A, Matías V, Pino M, Bernardo D, Arranz E, Blanco-Quiros A. Predominance of Th2 cytokines, CXC chemokines and innate immunity mediators at the mucosal level during severe respiratory syncytial virus infection in children. Eur Cytokine Netw. 2007;18:162-7.

Boelen A, Kwakkel J, Barends M, De Rond I, Dormans J, Kimman T. Effect of lack of Interleukin-4, Interleukin-12, Interleukin-18, or the Interferon-gamma receptor on virus replication, cytokine response, and lung pathology during respiratory syncytial virus infection in mice. J Med Virol. 2002;66:552-60.

Boukhvalova MS, Yim KC, Kuhn KH, Hemming JP, Prince GA, Porter DD, Blanco JCG. Age-related differences in pulmonary cytokine response to respiratory syncytial virus infection: modulation by anti-inflammatory and antiviral treatment. $J$ Infect Dis. 2007;195:511-8. 
Bont L, Heijnen CJ, Kavelaars A, van Aalderen WM, Brus F, Draaisma JT, Geelen SM, KimpenJL. Monocyte IL-10 production during respiratory syncytial virus bronchiolitis is associated with recurrent wheezing in a oneyear follow-up study. Am J Respir Crit Care Med. 2000;161:1518-23.

Bourgeois C, Bour JB, Lidholt K, Gauthray C, Pothier P. Heparin-like structures on respiratory syncytial virus are involved in its infectivity in vitro. $J$ Virol. 1998;72:7221-7.

Brandenburg AH, Van Beek R, Moll HA, Osterhaus ADME, Claas ECJ. G protein variation in respiratory syncytial virus group A does not correlate with clinical severity. J Clin Microbiol. 2000;38:3849-52.

Brouard J, Freymuth F, Constantini S, Petitjean J, de Schrevel G, Duhamel F. Prévalence et aspects cliniques de l'infection par les sous-types A et B du virus respiratoire syncytial. Arch Fr Pediatr. 1993;50:639-43.

Candeias JAN. Isolamento de vírus respiratório sincicial em crianças com quadro respiratório agudo. Rev Inst Med trop São Paulo. 1967;9:27-30.

Chandwani S, Borkowsky W, Krasinski K, Lawrence $\mathrm{R}$, Welliver $\mathrm{R}$. Respiratory syncytial virus infection in human immunodeficiency virusinfected children. J Pediatr. 1990;117:251-4. 
Chang J, Choi SY, Jin HT, Sung YC, Braciale TJ. Improved effector activity and memory CD8 T cell development by IL-2 expression during experimental respiratory syncytial virus infection. $J$ Immunol. 2004;172:503-8.

Chanock RM, Finberg L. Recovery from infants with respiratory illness of a virus related to chimpanzee coryza agent (CCA). II. Epidemiological aspects of infection in infants and young children. Am J Hyg. 1957a;66:291-300.

Chanock RM, Roizman B, Myers R. Recovery from infants with respiratory illness of a virus related to chimpanzee coryza agent (CCA). I. Isolation properties and characterization. Am J Hyg. 1957b;66:281-90.

Chung HL, Kim SG. RANTES may be predictive of later recurrent wheezing after respiratory syncytial virus bronchiolitis in infants. Ann Allergy Asthma Immunol. 2002;88:463-7.

Chung HL, Kim WT, Kim JK, Choi EJ, Lee JH, Lee GH, Kim SG. Relationship between atopic status and nasal interleukin 10 and 11 levels in infants with respiratory syncytial virus bronchiolitis. Ann Allergy Asthma Immunol. 2005;94:267-72.

Chung HL, Park HJ, Kim SY, Kim SG. Age-related difference in immune responses to respiratory syncytial virus infection in young children. Pediatr Allergy Immunol. 2007;18:94-9. 
Cintra OAL, Owe MA, Machado AA, Cerwi MC, Figueiredo LT, Rocha GM, Siqueira MM, Arruda E. Occurrence and severity of infections caused by subgroup A and B respiratory syncytial virus in children in Southeast Brazil. $J$ Med Virol. 2001;65:408-12.

Combadière $\mathrm{B}$, Faure $\mathrm{S}$, Autran $\mathrm{B}$, Debré $\mathrm{P}$, Combadière $\mathrm{C}$. The chemokine receptor CX3CR1 controls homing and anti-viral potencies of CD8 effectormemory T lymphocytes in HIV-infected patients. AIDS. 2003;17:1279-90.

Connors M, Kulkarni AB, Collins PL, Firestone CY, Holmes KL, Morse HC 3rd, Murphy BR. Resistance to respiratory syncytial virus (RSV) challenge induced by infection with a vaccinia virus recombinant expressing the RSV M2 protein (Vac-M2) is mediated by $\mathrm{CD}^{+} \mathrm{T}$ cells, while that induced by VacF or Vac-G recombinants is mediated by antibodies. J Virol. 1992;66:127781.

Cox MJ, Azevedo RS, Cane PA, Massad E, Medley GF. Seroepidemiological study of respiratory syncytial virus in São Paulo state, Brazil. J Med Virol. 1998;55:234-9.

Crowe JE Jr, Suara RO, Brock S, Kallewaard N, House F, Weitkamp JH. Genetic and structural determinants of virus neutralizing antibodies. Immunol Res. 2001;23:135-45. 
Cunningham CK, McMillan JA, Gross SJ. Rehospitalization for respiratory illness in infants of less than 32 weeks' gestation. Pediatrics. 1991;88:52732.

David E, McIntosh G, De Silva LM, Oates RK. Clinical severity of respiratory syncytial vírus group A and B infection in Sydney, Australia. Pediatr Infect Dis J. 1993;12:815-9.

De Boeck K, Van der Aa N, Van Lierde S, Corbeel L, Eeckels R. Respiratory syncytial virus bronchiolitis: a double-blind dexametasone efficacy study. $J$ Pediatr. 1997;131:919-21.

Diniz EMA, Vieira RA, Ceccon MEJR, Ishida MA, Vaz FAC. Incidence of respiratory viruses in preterm infants submitted to mechanical ventilation. Rev Inst Med trop São Paulo. 2005;47:37-44.

Duperray A, Languino LR, Plescia J, McDowall A, Hogg N, Craig A, Berendt AR, Altieri DC. Molecular identification of a novel fibrinogen binding site on first domain of ICAM-1 regulating leukocyte-endothelium. J Biol Chem. 1997;272:435-41. 
Durbin JE, Johnson TR, Durbin RK, Mertz SE, Morotti RA, Peebles RS, Graham BS. The role of IFN in respiratory syncytial virus pathogenesis. $J$ Immunol. 2002;168:2944-52.

Ehlenfield DR, Cameron K, Welliver RC. Eosinophilia at the time of respiratory syncytial virus bronchiolitis predicts childhood reactive airway disease. Pediatrics. 2000;105:79-83.

Filippell MB, Rearick T. Respiratory syncytial virus. Nurs Clin North Am. 1993;28:651-71.

Ford-Jones EL. The special problems of nosocomial infection in pediatric patient. In: Wenzel RP, editor. Prevention and control of nosocomialinfections. 2nd ed. Baltimore: Williams and Wilkins; 1993. p.81296.

Forster J, Schumacher RF. The clinical picture presented by premature neonates infected with the respiratory syncytial virus. Eur $J$ Pediatr. $1995 ; 154: 901-5$

Frankel LR, Derish MT. Respiratory syncytial virus-induced respiratory failure in the pediatric patient. New Horiz. 1999;7:335-46. 
Fraticelli P, Sironi M, Bianchi G, D'Ambrosio D, Albanesi C, Stoppacciaro A, Chieppa M, Allavena P, Ruco L, Girolomoni G, Sinigaglia F, Vecchi A, Mantovani A. Fractalkine (CX3CL1) as an amplification circuit of polarized Th1 responses. J Clin Invest. 2001;107:1173-81.

Fuentes S, Tran KC, Luthra P, Teng MN, He B. Function of the respiratory syncytial virus small hydrophobic protein. J Virol. 2007;81:8361-6.

Gagro A, Tominac M, Krsulovic-Hresic V, Bace A, Matic M, Drazenovic V, Mlinaric-Galinovic G, Kosor E, Gotovac k, Bolanca I, Batinica S, Rabatic S. Increased Toll-like receptor 4 expression in infants with respiratory syncytial virus bronchiolitis. Clin Exp Immunol. 2004;135:267-72.

Garofalo RP, Haeberle H. Epithelial regulation of innate immunity to respiratory syncytial virus. Am J Respir Cell Mol Biol. 2000;23:581-5.

Garofalo RP, Patti J, Hintz KA, Hill V, Ogra PI, Welliver RC. Macrophage inflammatory protein-1alpha (not T helper type 2 cytokines) is associated with severe forms of respiratory syncytial virus bronchiolitis. J Infect Dis. 2001; 184:393-9.

Gentile DA, Doyle WJ, Zeevi A, Howe-Adams J, Kapadia S, Trecki J, Skoner DP. Cytokine gene polymorphisms moderate illness severity in infants with respiratory syncytial virus infection. Hum Immunol. 2003;64:338-44. 
Gern JE, Busse WW. The role of viral viral infections in the natural history of asthma. J Allergy Clin Immunol. 2000;106:201-12.

Gilchrist S, Torok TJ, Gary HE Jr, Alexander JP, Anderson LJ. National surveillance for respiratory syncytial virus, United States, 1985-1990. J Infect Dis. 1994;170:986-90.

Giugno KM, Machado DC, Amantéa SL, Barreto SSM. Concentrations of interleukin-2 in the nasopharyngeal secretion of children with acute respiratory syncytial virus bronchiolitis. J Pediatr (Rio J). 2004;80:315-20.

Graham BS, Rutigliano JA, Johnson TR. Respiratory syncytial virus immunobiology and pathogenesis. Virology. 2002;297:1-7.

Guerrero-Plata A, Ortega E, Ortiz-Navarrete V, Gómez B. Antigen presentation by a macrophage-like cell line persistently infected with respiratory syncytial virus. Virus Res. 2004;99:95-100.

Haddad JJ. Cytokines and related receptor-mediated signaling pathways. Biochem Biophys Res Commun. 2002;297:700-13.

Haeberle HA, Takizawa R, Casola A, Brasier AR, Dieterich HJ, Van Rooijen N, Gatalica Z, Garofalo RP. Respiratory syncytial virus-induced activation of 
nuclear factor-kappaB in the lung involves alveolar macrophages and toll-like receptor 4-dependent pathways. J Infect Dis. 2002;186:1199-206.

Hall CB. Respiratory syncytial virus: a continuing culprit and conundrum. $J$ Pediatr. 1999;135:2-7.

Hall CB. Respiratory syncytial virus. In: Feigin RD, editor. Textbook of pediatric infectious diseases. 4th ed. Philadelphia: Saunders; 1998. p.2084111.

Hall CB, Walsh EE, Schnabel KC, Long CE, McConnochie KM, Hildreth SW, Anderson LJ. Occurrence of groups A and B of respiratory syncytial virus over 15 years: associated epidemiological and clinical characteristics in hospitalized and ambulatory children. J Infect Dis. 1990;162:1283-90.

Harrison AM, Bonville CA, Rosenberg HF, Domachowske JB. Respiratory syncytical virus-induced chemokine expression in the lower airways: eosinophil recruitment and degranulation. Am J Respir Crit Care Med. 1999; 159:1918-24.

Hawrylowicz CM. Regulatory T cells and IL-10 in allergic inflammation. J Exp Med. 2005;202:1459-63. 
Haynes LM, Jones LP, Barskey A, Anderson LJ, Tripp RA. Enhanced disease and pulmonary eosinophilia associated with formalin-inactivated respiratory syncytial virus vaccination are linked to $G$ glycoprotein $C X 3 C$ CX3CR1 interaction and expression of substance P. J Virol. 2003;77:983144.

Haynes LM, Moore DD, Kurt-Jones EA, Finberg RW, Anderson LJ, Tripp RA. Involvement of toll-like receptor 4 in innate immunity to respiratory syncytial virus. J Virol. 2001;75:10730-7.

Haynes LM, Tonkin J, Anderson LJ, Tripp RA. Neutralizing anti-F glycoprotein and anti-substance $P$ antibody treatment effectively reduces infection and inflammation associated with respiratory syncytial virus infection. J Virol. 2002;76:6873-81.

Hemming VG. Viral respiratory diseases in children: classification, etiology, epidemiology and risk factors. J Pediatr. 1994;124(Suppl.):S13-6.

Hendricks DA, Mclntosh K, Patterson JL. Further characterization of the soluble form of the G glycoprotein of respiratory syncytial virus. J Virol. 1988; 62:2228-33. 
Hendry RM, Tails AL, Godfrey E, Anderson LJ, Fernie BF, Mclntosh K. Concurrent circulation of antigenically distinct strains of respiratory syncytial virus during community outbreaks. J Infect Dis. 1986;153:291-7.

Holberg CJ, Wright AL, Martinez FD. et al. Risk factors for respiratory syncytial virus- associated lower respiratory illnesses in the first year of life. Am J Epidemiol. 1991;133:1135-51.

Hornsleth A, Klug B, Nir M, Johansen J, Hansen K, Christensen LS, Larsen LB. Severity of respiratory syncytial virus disease related to type and genotype of virus and to cytokine values in nasopharyngeal secretions. Pediatr Infect Dis J. 1998;17:1114-21.

Hornsleth A, Loland L, Larsen LB. Cytokines and chemokines in respiratory secretion and severity of disease in infants with respiratory syncytial virus (RSV) infection. J Clin Virol. 2001;21:163-70.

Hull J, Rowlands K, Lockhart E, Moore C, Sharland M, Kwiatkwski D. Variants of the chemokine receptor CCR5 are associated with severe bronchiolitis caused by respiratory syncytial virus. J Infect Dis. 2003;188:9047. 
Imaz MS, Sequeira MD, Videla C, Veronessi I, Cociglio R, Zerbini E, Carballal G. Clinical and epidemiology characteristics of respiratory syncytial virus subgroups A and B infections in Santa Fé, Argentina. J Med Virol. 2000; 61:76-80.

Jafri HS, Carubelli CM, Sheeran P, Saavedra J, Sanchez PJ, Ramilo O. Systemic IL-6, IL-8, and RANTES response in children with respiratory syncytial virus disease. Pediatr Res. 1999;45:164A. (Presented at The American Pediatric Society and The Society for Pediatric Research; 1999. Abstracts).

Jaovisidha P, Peeples ME, Brees AA, Carpenter LR, Moy JN. Respiratory syncytial virus stimulates neutrophil degranulation and chemokine release. $J$ Immunol. 1999;163:2816-20.

Justice JP, Shibata Y, Sur S, Mustafa J, Fan M, van Scott MR. IL-10 gene knockout attenuates allergen-induced airway hyperresponsiveness in C57BL/6 mice. Am J Physiol Lung Cell Mol Physiol. 2001;280:363-8.

Kawasaki Y, Hosoya M, Kanno H, Suzuki H. Serum regulated upon activation, normal T cell expressed and presumably secreted concentrations and eosinophils in respiratory syncytial virus infection. Pediatr Int. 2006;48:257-60. 
Kilpatrick L, Harris MC. Cytokines and inflammatory response in the fetus and neonate. In: Polin RA, Fox WW, Abman SH, editors. Fetal and neonatal physiology. 3rd ed. Philadelphia: Saunders; 2004. p.1555-72.

Kneyber MCJ, Brandenburg $\mathrm{AH}$, Rothbarth $\mathrm{PH}$, de Groot R, Ott $\mathrm{A}$, van Steensel-Moll HA. Relationship between clinical severity of respiratory syncytial virus infection and subtype. Arch Dis Child. 1996;75:137-40.

Krishnan S, Craven M, Welliver RC, Ahmad N, Halonen M. Differences in participation of innate and adaptative immunity to respiratory syncytial virus in adults and neonates. $J$ Infect Dis. 2003;188:433-9.

Krishnan S, Halonen M. Suppression of innate immune cytokines and interferon regulatory factor- 1 by endogenous interferon-alpha in response to respiratory syncytial virus in neonate mononuclear cells. Immunol Invest. 2007;36:441-56.

Kurt-Jones EA, Popova L, Kwinn L, Haynes LM, Jones LP, Tripp RA, Walsh EE, Freeman Mw, Golenbock DT, Anderson LJ, Finberg RW. Pattern recognition receptors TLR4 and CD14 mediate response to respiratory syncytial virus. Nat Immunol. 2000;1:398-401. 
Lai CC, Tai HY, Shen HD, Chung WT, Chung RL, Tang RB. Elevated levels of soluble adhesion molecules in sera of patients with acute bronchiolitis. $J$ Microbiol Immunol Infect. 2004;37:153-6.

Legg JP, Johnston SL. Respiratory syncytial virus infection: determinants of disease severity. Clin Pulm Med. 2002;9:306-14.

Legg JP, Hussain IR, Warner JA, Johnston SL, Warner JO. Type 1 and type 2 cytokine imbalance in acute respiratory syncytial virus bronchiolitis. $A m \mathrm{~J}$ Respir Crit Care Med. 2003;168:633-9.

LeVine AM, Gwozdz J, Stark J, Bruno M, Whitsett J, Korfhagen T. Surfactant protein-A enhances respiratory syncytial virus clearance in vivo. J Clin Invest. 1999;103:1015-21.

Liu T, Castro S, Brasier AR, Jamaluddin M, Garofalo RP, Casola A. Reactive oxygen species mediate viral-induced STAT activation: role of tyrosine phosphatases. J Biol Chem. 2004;279:2461-69.

Luger TA. Neuromediators - a crucial component of the skin immune system. J Dermatol Sci. 2002;30:87-93. 
Madge P, Paton JY, McColl JH, Mackie PLK. Prospective controlled study of four infection- control procedures to prevent nosocomial infection with respiratory syncytial virus. Lancet. 1992;340:1079-83.

Mäkelä MJ, Kanehiro A, Dakhama A, Borish L, Joetham A, Tripp R, Anderson L, Gelfand EW. The failure of interleukin-10-deficient mice to develop airway hyperresponsiveness is overcome by respiratory syncytial virus infection in allergen-sensitized/ challenged mice. Am J Respir Crit Care Med. 2002;165:824-31.

Malhotra R, Ward M, Bright H, Priest R, Foster MR, Hurle M, Blair E, Bird M. Isolation and characterisation of potential respiratory syncytial virus receptor(s) on epithelial cells. Microbes Infect. 2003;5:123-33.

Malley R, De Vincenzo J, Ramilo O, Dennehy PH, Meissner HC, Gruber WC, Sanchez PJ, Jafri H, Balsley J, Carlin D, Buckingham S, Vernacchio L, Ambrosino DM. Reduction of respiratory syncytial virus (RSV) in tracheal aspirates in intubated infants by use of humanized monoclonal antibody to RSV F protein. J Infect Dis. 1998;178:1555-61.

Mariscalco MM. Integrins and cell adhesion molecules. In: Polin RA, Fox WW, Abman SH, editors. Fetal and neonatal physiology. 3rd ed. Philadelphia: Saunders; 2004. p.1572-91. 
Martinez I, Melero JA. Binding of human respiratory syncytial virus to cells: implication of sulfated cell surface proteoglycans. J Gen Virol. 2000;81:271522.

Marty A, Meanger J, Mills J, Shields B, Ghildyal R. Association of matrix protein of respiratory syncytial virus with the host cell membrane of infected cells. Arch Virol. 2004;149:199-210.

Matsuda K, Tsutsumi H, Okamoto Y, Chiba C. Development of interleukin 6 and tumor necrosis factor alpha activity in nasopharyngeal secretions of infants and children during infection with respiratory syncytial virus. Clin Diagn Lab Immunol. 1995;2:322-4.

McCarthy PL, Klig JE, Kahn JS. Fever without apparent source on clinical examination, lower respiratory infections in children, and other infectious diseases. Curr Opin Pediatr. 1999;11:89-106.

McConnochie KM, Hall CB, Walsh EE, Roghmann KJ. Variation in severity of respiratory syncytial virusinfections with subtype. J Pediatr. 1990;117:52-62.

McIntosh EDG, De Silva LM, Oates RK. Clinical severity of respiratory syncytial virus group A and B infection in Sidney, Australia. Pediatr Infect Dis J. 1993;12:815-9. 
McNamara PS, Flanagan BF, Selby AM, Hart CA, Smyth RL. Pro- and antiinflammatory responses in respiratory syncytial virus bronchiolitis. Eur Respir J. 2004;23:106-12.

McNamara PS, Smyth RL. The pathogenesis of respiratory syncytial virus disease in childhood. Br Med Bull. 2002;61:13-28.

Meert K, Heidemann S, Abella B, Sarnaik A. Does prematurity alter the course respiratory syncytial virus infection? Crit Care Med. 1990;18:1357-9.

Meissner HC, Welliver RC, Chartrand AS, Fulton DR, Rodriguez WJA, Groothuis JR. Prevention of respiratory syncytial virus infection in high risk infants: consensus opinion on the role of immunoprophylaxis with respiratory syncytial virus hyperimmune globulin. Pediatr Infect Dis J. 1996;15:1059-68.

Meissner HC, Welliver RC, Chartrand SA, Law BJ, Weisman LE, Dorkin HL, Rodriguez WJ. Immunoprophylaxis with palivizumab, a humanized respiratory syncytial virus monoclonal antibody, for prevention of respiratory syncytial virus infection in high risk infants: a consensus opinion. Pediatr Infect Dis J. 1999;18:223-31.

Mello WA, Silva C. Epidemiological aspects of RSV subgroups in Belém, Brazil. Boletin Latino-Americano. 1992;1:8. 
Miyao CR, Gilio AE, Vieira S, Hein N, Pahl MMC, Betta SL, Durigon EL, Stewien KE, Queiroz DAO, Botosso VF, Gomes MCS, Lopes CLBC, Ejzemberg B, Okay Y. Infecções virais em crianças internadas por doença aguda do trato respiratório inferior. J Pediatr (Rio J). 1999;75:334-44.

Monick MM, Yarovinsky TO, Powers LS, Butler NS, Carter AB, Gudmundsson G, Hunninghake GW. Respiratory syncytial virus up-regulates TLR4 and sensitizes airway epithelial cells to endotoxin. $J$ Biol Chem. 2003;278:53035-44.

Monto AS, Ohmit S. Respiratory syncytial virus in a community population: circulation of subgroups A and B since 1965. J Infect Dis. 1990;161:781-3.

Moore KW, O'Garra A, Malefyt RW, Vieira P, Mosmann TR. Interleukin-10. Ann Rev Immunol. 1993;11:165-90.

Morris JA, Blount RE, Savage RE. Recovery of cytopathogenic agent from chimpanzees with coryza. Proc Soc Exp Biol Med. 1956;92:544-9.

Moura FEA, Borges LC, Portes SAR, Ramos EAG, Siqueira MM. Respiratory syncytial virus infections during an epidemic period in Salvador, Brazil. Viral antigenic group analysis and description of clinical and epidemiological aspects. Mem Inst Oswaldo Cruz. 2003;98:739-43. 
Mufson MA, Belshe RB, Orvell C, Norrby E. Respiratory syncytial virus epidemics: variable dominance of subgroups A and B strains among children, 1981-1986. J Infect Dis. 1988;157:143-8.

Murai H, Terada A, Mizuno M, Asai M, Hirabayashi Y, Shimizu S, Morishita T, Kakita H, Hussein MH, Ito T, Kato I, Asai k, Togari H. IL-10 and RANTES are elevated in nasopharyngeal secretions of children with respiratory syncytial virus infection. Allergol Int. 2007;56:157-63.

Murphy BR, Graham BS, Prince GA, Walsh EE, Chanock RM, Karzon DT, Wright PF. Serum and nasal-wash immunoglobulin $G$ and $A$ antibody response of infants and children to respiratory syncytial virus $F$ and $G$ glycoproteins following primary infection. J Clin Microbiol. 1986;23:1009-14.

Nascimento JP, Siqueira MM, Sutmoller F, Krawczuk MM, Farias V, Ferreira V, Rodrigues MJ. Longitudinal study of acute respiratory diseases in Rio de Janeiro: occurrence of respiratory viruses during four consecutives years. Rev Inst Med trop São Paulo. 1991;33:287-96.

Noah TL, Ivins SS, Murphy P, Kazachkova I, Moats-Staats B, Henderson FW. Chemokines and inflammation in the nasal passages of infants with respiratory syncytial virus bronchiolitis. Clin Immunol. 2002;104:86-95. 
Ogra PL. Respiratory syncytial virus: the virus, the disease and the immune response. Paediatr Respir Rev. 2004;5:119-26.

Okamoto Y, Brodsky L, Bernstein JM, Ogra PL. Characteristics of in vitro production of mucosal antibody to respiratory syncytial virus in tonsillar tissue lymphocytes. Clin Immunol Immunopathol. 1988;49:299-307.

Okuonghae HO, Nwankwo UM, Okolo AA, Schuit KE. Nosocomial respiratory syncytial virus infection in a newborn nursery. Ann Trop Paediatr. 1992;12:185-93.

Oliveira TFM, Freitas GRO, Ribeiro LZG, Yokosawa J, Siqueira MM, Portes SAR, Silveira HL, Calegari T, Costa LF, Mantese OC, Queiróz DAO. Prevalence and clinical aspects of respiratory syncytial virus A and B groups in children seen at Hospital de Clínicas of Uberlândia, MG, Brazil. Mem Inst Oswaldo Cruz. 2008;103:417-22.

Olszewska-Pazdra KB, Casola A, Saito T, Alam R, Crowe SE, Mei F, Ogra PL, Garofalo RP. Cell-specific expression of RANTES, MCP-1, and MIP1alpha by lower airway epithelial cells and eosinophils infected with respiratory syncytial virus. J Virol. 1998;72:4756-64. 
Openshaw PJ. Antiviral immune responses and lung inflammation after respiratory syncytial virus infection. Proc Am Thorac Soc. 2005;2:121-5.

Openshaw PJ. Immunopathological mechanisms in respiratory syncytial virus disease. Springer Semin Immunopathol. 1995;17:187-201.

Openshaw PJ, Culley FJ, Olszewska W. Immunopathogenesis of vaccineenhanced RSV disease. Vaccine. 2001;20(Suppl.):S27-S31.

Openshaw PJ, Dean GS, Culley FJ. Links between respiratory syncytial virus bronchiolitis and childhood asthma: clinical and research approaches. Pediatr Infect Dis J. 2003;22:58-64.

Paiva MAS, Reis FJC, Fisher GB, Rozov T. Pneumonias na criança. I Consenso brasileiro sobre pneumonias. J Pneumol. 1998;24:101-8.

Panuska JR, Merolla R, Rebert NA, Hoffmann SP, Tsivitse P, Cirino NM, Silverman RH, Rankin JA. Respiratory syncytial virus induces interleukin-10 by human alveolar macrophages. Suppression of early cytokine production and implications for incomplete immunity. J Clin Invest. 1995;96:2445-53.

Peebles RS, Hashimoto K Jr, Graham BS. The complex relationship between respiratory syncytial virus and allergy in lung disease. Viral Immunol. 2003;16:25-34. 
Peret TC, Hall CB, Hammond GW, Piedra Pa, Storch GA, Sullender WM, Tsou C, Anderson LJ. Circulation patterns of group A and B human respiratory syncytial virus genotypes in 5 communities in North America. $J$ Infect Dis. 2000;181:1891-6.

Piedimonte G. Contribution of neuroimmune mechanisms to airway inflammation and remodeling during and after respiratory syncytial virus infection. Pediatr Infect Dis J. 2003;22(Suppl.):S66-S75.

Piedimonte G, Hegele RG, Auais A. Persistent airway inflammation after resolution of respiratory syncytial virus infection in rats. Pediatr Res. 2004; 55:657-65.

Pinto RA, Arredondo SM, Bono MR, Gaggero AA, Díaz PV. T helper 1/T helper 2 cytokine imbalance in respiratory syncytial virus infection is associated with increased endogenous plasma cortisol. Pediatrics. 2006; 117:878-86.

Pitrez PM, Ponzi D, Machado DC, Bauer ME, Jones MH, Stein RT. Discrepancy between cytokine production from peripheral blood mononuclear cells and nasal secretions among infants with acute bronchiolitis. Ann Allergy Asthma Immunol. 2004;92:659-62. 
Polack FP, Teng MN, Collins PL, Prince GA, Exner M, Regele H, Lirman DD, Rabold R, Hoffman SJ, Karp CL, Kleeberger SR, Wills-Karp M, Karron RA. A role for immune complexes in enhanced respiratory syncytial virus disease. $J$ Exp Med. 2002;196:859-65.

Queiróz DAO, Durigon EL, Botosso VF, Ejzemberg B, Vieira SE, Mineo JR, Yamashita C, Hein N, Lopes CL, Cacharo AL, Stewien KE. Immune response to respiratory syncytial virus in young brazilian children. Braz J Med Biol Res. 2002;35:1183-93.

Romagnoli C, Frezza S, Cingolanio A, De Luca A, Puopolo M, De Carolis MP, Vento G, Antinori A, Tortorolo G. Plasma levels of interleukin-6 and interleukin-10 in preterm neonates evaluated for sepsis. Eur $J$ Pediatr. $2001 ; 160: 345-50$.

Russi JC, Chiparelli H, Montano A, Etorena P, Hortal M. Respiratory syncytial virus subgroups and pneumonia in children. Lancet. 1989;2:1039-40.

Ruuskanen O, Ogra PL. Respiratory syncytial virus. Curr Probl Pediatr. 1993;23:50-79. 
Salomón HE, Avila MM, Cerqueiro MC, Orvell C, Weissenbacher M. Clinical and epidemiological aspects of respiratory syncytial virus antigenic variants in Argentinian children. J Infect Dis. 1991;163:1167.

Sano H, Nagai K, Tsutsumi H, Kuroki Y. Lactoferrin and surfactant protein A exhibit distinct binding specificity to $\mathrm{F}$ protein and differently modulate respiratory syncytial virus infection. Eur J Immunol. 2003;33:2894-902.

Schwarze J, O'Donnell DR, Rohwedder A, Openshaw PJ. Latency and persistence of respiratory syncytial virus despite T cell immunity. Am J Respir Cri. Care Med. 2004;169:801-5.

Sheeran P, Jafri H, Carubelli C, Saavedra J, Johnson C, Krisher K, Sánchez PJ, Ramilo O. Elevated cytokine concentrations in the nasopharyngeal and tracheal secretions of children with respiratory syncytial virus disease. Pediatr Infect Dis J. 1999;18:115-22.

Shepherd VL. Distinct roles for lung collectins in pulmonary host defense. Am J Respir Cell Mol Biol. 2002;26:257-60.

Siqueira MM, Nascimento JP, Anderson LJ. Antigenic characterization of RSV group A and B isolates in Rio de Janeiro, Brazil. J Clin Microbiol. $1991 ; 29: 557-9$. 
Smyth RL, Fletcher JN, Thomas HM, Hart CA. Immunological responses to respiratory syncytial virus infection in infancy. Arch Dis Child. 1997;76:210-4.

Smyth RL, Mobbs KJ, O'Hea U, Ashby D, Hart CA. Respiratory syncytial virus bronchiolitis: disease severity, interleukin-8, and virus genotype. Pediatr Pulmonol. 2002;33:339-46.

Stark JM, Fatemi SH, Amini SB, Huang YT. Occurrence of respiratory syncytial virus subtypes in hospitalized children in Cleveland, Ohio from 1985 to 1988. Pediatr Pulmonol. 1991;11:98-102.

Stein RT, Martinez FD. Asthma phenotypes in childhood: lessons from an epidemiological approach. Paediatr Respir Rev. 2004;5:155-61.

Stevens WW, Falsey AR, Braciale TJ. RSV 2007: recent advances in respiratory syncytial virus research. Viral Immunol. 2008;21:133-40.

Straliotto SM, Nestor SM, Siqueira MM. Respiratory syncytial virus group A and B in Porto Alegre, Brazil, from 1990 to 1995 and 1998. Mem Inst Oswaldo Cruz. 2001;96:155-8.

Stretton M, Ajizian SJ, Mitchell I, Newth CJL. Intensive care course and outcome of patients infected with respiratory syncytial virus. Pediatr Pulmonol. 1992;13:143-50. 
Sullender W. Respiratory syncytial virus genetic and antigenic diversity. Clin Microbiol Rev. 2000;13:1-15.

Sutmöller F, Andrade Ferro ZP, Asensi MD, Ferreira V, Mazzei IS, Cunha BL. Etiology of acute respiratory tract infections among children in a combined community and hospital study in Rio de Janeiro. Clin Infect Dis. 1995;20:854-60.

Tang YW, Graham BS. Anti-IL-4 treatment at immunization modulates cytokine expression, reduces illness, and increases cytotoxic $\mathrm{T}$ lymphocyte activity in mice challenged with respiratory syncytial virus. J Clin Invest. 1994;94:1953-8.

Techaarpornkul S, Collins PL, Peeples ME. Respiratory syncytial virus with the fusion protein as its only viral glycoprotein is less dependent on cellular glycosaminoglycans for attachment than complete virus. Virology. 2002;294:296-304.

The University of Warwick. Respiratory syncytial virus. [Online]. [17 nov 2008]. Available from: http://www.bio.warwick.ac.uk/easton/images/Diagrams/3dvirus.html. 
Tirado R, Sarmiento RE, Bustos J, Thompson O, Gomez B. Occurrence of respiratory syncytial virus subtypes in mexican infants with acute lower respiratory tract disease. Arch Med Res. 1995;26:121-6.

Tissing WJE, vanSteensel-Moll HA, Offringa M. Risk factors for mechanical ventilation in respiratory syncytial virus infection. Eur $J$ Pediatr. 1993;152:125-7.

Tripp RA. Pathogenesis of respiratory syncytial virus infection. Viral Immunol 2004;17:165-81.

Tripp RA, Dakhama A, Jones LP, Barskey A, Gelfand EW, Anderson LJ. The G glycoprotein of respiratory syncytial virus depresses respiratory rates through the CX3C motif and substance P. J Virol. 2003;77:6580-4.

Tripp RA, Jones LP, Haynes LM, Zheng H, Murphy PM, Anderson LJ. CX3C chemokine mimicry by respiratory syncytial virus $G$ glycoprotein. Nat Immunol. 2001;2:732-8.

Tripp RA, Moore D, Barskey A 4th, Jones L, Moscatiello C, Keyserling H, Anderson LJ. Peripheral blood mononuclear cells from infants hospitalized because of respiratory syncytial virus infection express $T$ helper-1 and $T$ helper-2 cytokines and CC chemokine messenger RNA. J Infect Dis. 2002;185:1388-94. 
Tripp RA, Moore D, Winter J, Anderson LJ. Respiratory syncytial virus infection and $\mathrm{G}$ and/or $\mathrm{SH}$ protein expression contribute to substance $\mathrm{P}$, which mediates inflammation and enhanced pulmonary disease in BALB/c mice. J Virol. 2000;74:1614-22.

Tripp RA, Oshansky C, Alvarez R. Cytokines and respiratory syncytial vírus infection. Proc Am Thorac Soc. 2005;2:147-9.

Underhill DM, Ozinsky A. Toll-like receptors: key mediators of microbe detection. Curr Opin Immunol. 2002;14:103-10.

Valarcher JF, Bourhy H, Lavenu A, Bourges-Abella N, Roth M, Andreoletti O, Ave P, Schelcher F. Persistent infection of B lymphocytes by bovine respiratory syncytial virus. Virology. 2001;291:55-67.

Valdovinos MR, Gomez B. Establishment of respiratory syncytial virus persistence in cell lines: association with defective interfering particles. Intervirology. 2003;46:190-8.

Varga SM, Braciale TJ. RSV-induced immunopathology: dynamic interplay between the virus and host immune response. Virology. 2002;295:203-7.

Vieira RA. Estudo clínico e laboratorial evolutivo de recém-nascidos portadores de infecção do trato respiratório inferior por vírus respiratórios 
[dissertação]. São Paulo: Faculdade de Medicina da Universidade de São Paulo; 2002.

Vieira RA, Diniz EMA, Vaz FAC. Clinical and laboratory study of newborns with lower respiratory tract infection due to respiratory viruses. J Matern Fetal Neonatal Med. 2003;13:341-50.

Vieira SE. Características do lactente hospitalizado com infecção do aparelho respiratório inferior por vírus sincicial respiratório: tipos e genotipos do vírus e anticorpos séricos específicos [tese]. São Paulo: Faculdade de Medicina da Universidade de São Paulo; 2004.

Vieira SE, Stewien KE, Queiroz DA, Durigon EL, Török TJ, Anderson LJ, Miyao CR, Hein N, Botosso VF, Pahl MM, Gilio AE, Ejzenberg B, Okay Y. Clinical patterns and seasonal trends in respiratory syncytial virus hospitalizations in São Paulo, Brazil. Rev Inst Med trop São Paulo. 2001;43: $125-31$

Vogel AM, Lennon DR, Broadbent R, Byrnes CA, Grimwood K, Midenhall L, Richardson V, Rowley S. Palivizumab prophylaxis of respiratory syncytial virus infection in high-risk infants. J Paediatr Child Health. 2002;38:550-4. 
Walsh EW, McConnochie KM, Long CE, Hall CB. Severity of respiratory syncytial virus infection is related to virus strain. $J$ Infect Dis. 1997;175:81420.

Wang CM, Tang RB, Chung RL, Hwang BT. Tumor necrosis factor-alpha and interleukin-6 profiles in children with pneumonia. J Microbiol Immunol Infect. 1999;32:233-8.

Wang EEL, Law BJ, Stephens D. Pediatric Investigators Collaborative Network on Infections in Canada (PICNIC): prospective study of risk factors and outcomes in patients hospitalized with respiratory syncytial virus lower respiratory tract disease. J Pediatr. 1995;126:212-9.

Wang SZ, Rosenberger CL, Bao YX, Stark JM, Harrod KS. Clara cell secretory protein modulates lung inflammatory and immune responses to respiratory syncytial virus infection. J Immunol. 2003;171:1051-60.

Weber MW, Dackour R, Usen S, Shneider G, Adegbola R, Cane P, Jaffar S, Milligan P, Greenwood B, Whittle H, Mulholland K. The clinical spectrum of respiratory syncytial virus disease in Gambia. Pediatr Infect Dis J. 1998;17: 224-30. 
Weinstock JV, Blum A, Metwali A, Elliott D, Arsenescu R. IL-18 and IL-12 signal through the NF-kappa B pathway to induce NK-1R expression on $T$ cells. J Immunol. 2003;170:5003-7.

Welliver RC. Respiratory syncytial virus and other respiratory viruses. Pediatr Infect Dis J. 2003;22(Suppl.):S6-S12.

Welliver RC, Kaul TN, Putnam TI, Sun M, Riddlesberger K, Ogra PL. The antibody response to primary and secondary infection with respiratory syncytial virus: kinetics of class-specific responses. J Pediatr. 1980;96:80813.

Wright AS, Bieluch VM. Selected nosocomial viral infections. Heart Lung. 1993;22:183-7.

Yui I, Hoshi A, Shigeta Y, Takami T, Nakayama T. Detection of human respiratory syncytial virus sequences in peripheral blood mononuclear cells. $J$ Med Virol. 2003;70:481-9.

Zhang Y, Luxon BA, Casola A, Garofalo RP, Jamaluddin M, Brasier AR. Expression of respiratory syncytial virus-induced chemokine gene networks in lower airway epithelial cells revealed by cDNA microarrays. $J$ Virol. 2001;75:9044-58. 